If you do not need this publication after it has served your purpose, please return it to the Geological Survey, using the official mailing label at the end

UNITED STATES DEPARTMENT OF THE INTERIOR TITANIUM DEPOSITS OF NELSON AND AMHERST COUNTIES VIRGINIA

GEOLOGICAL SURVEY PROFESSIONAL PAPER 198 


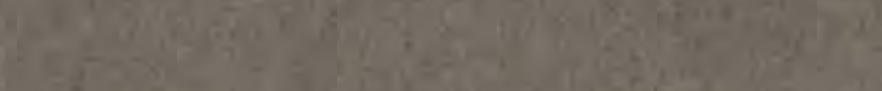

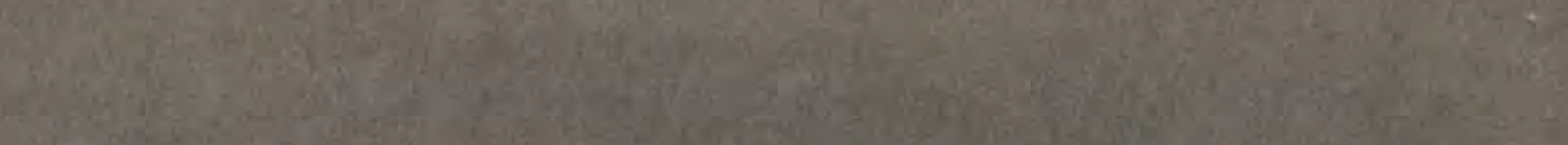
H.

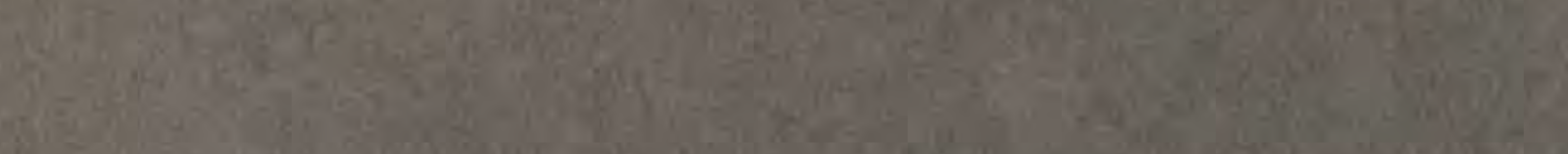

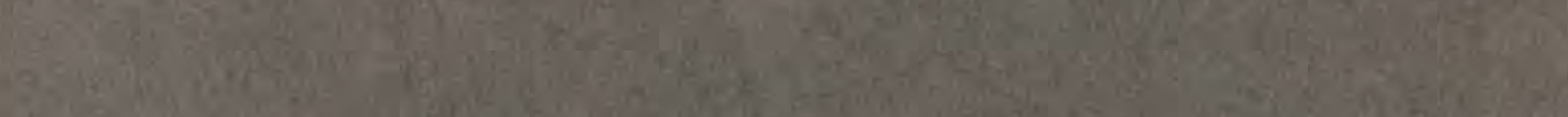
7.t.

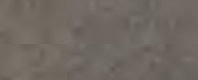

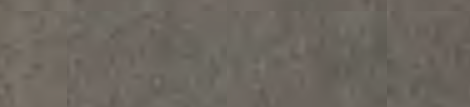

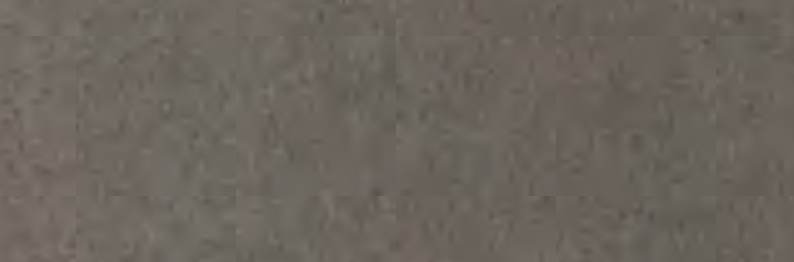

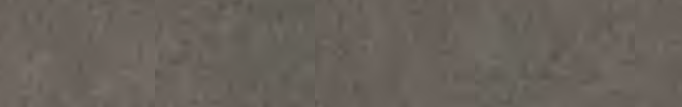

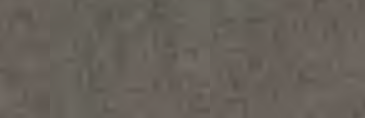

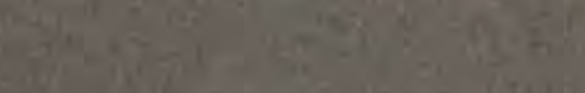

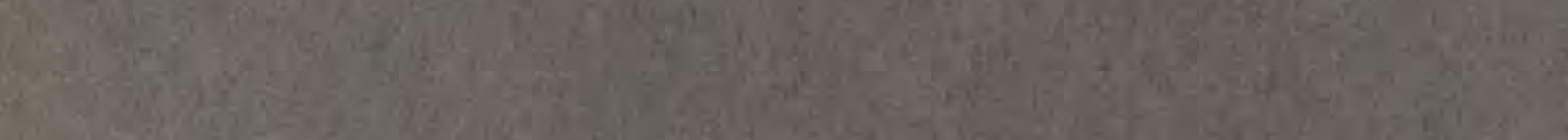

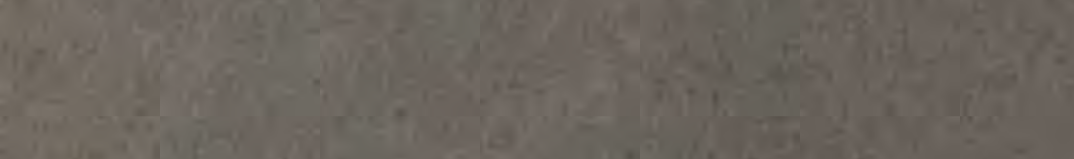

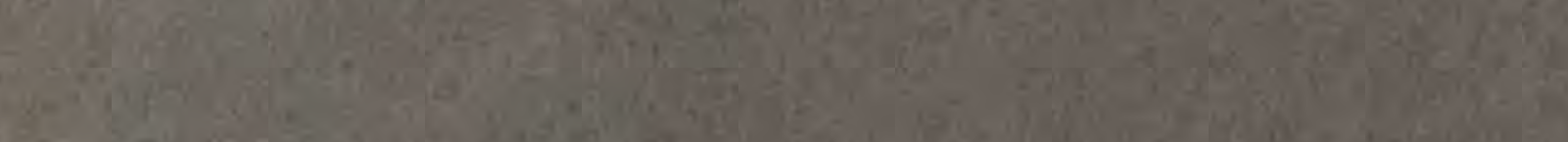

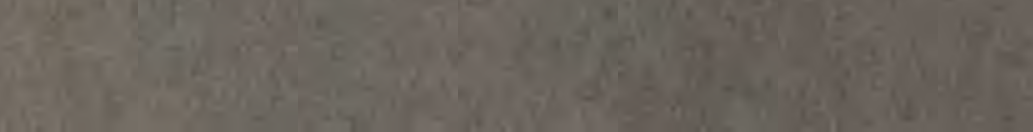

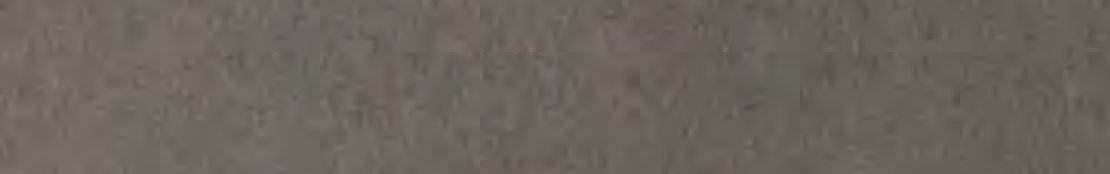

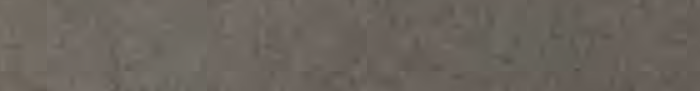

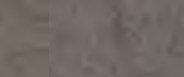

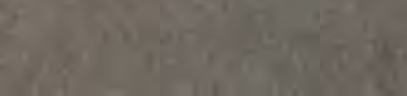

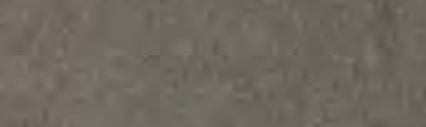

(1)

1.

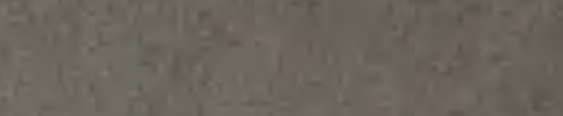

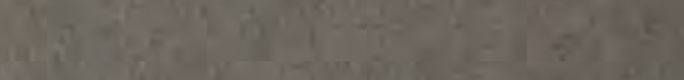

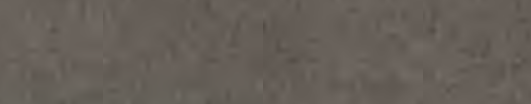

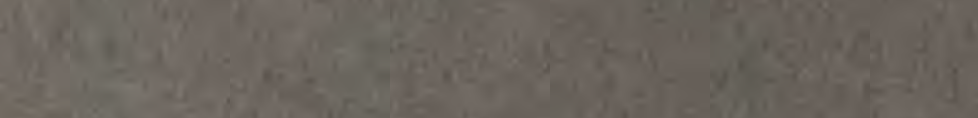
$t^{5}$

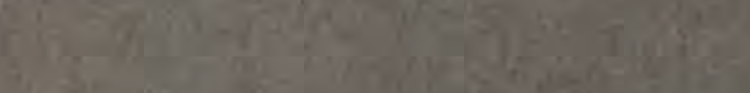

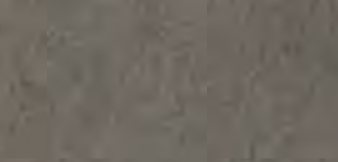

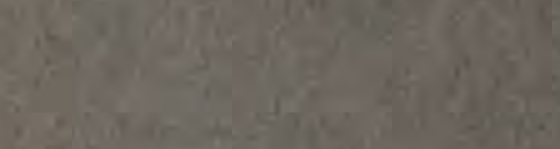

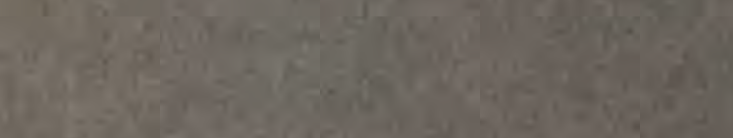

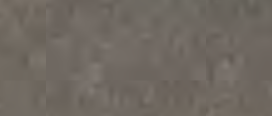

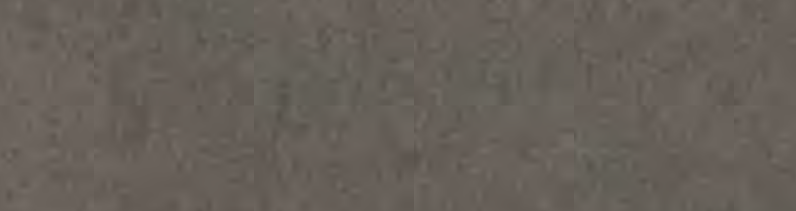


UNITED STATES DEPARTMENT OF THE INTERIOR

Harold L. Ickes, Secretary

GEOLOGICAL SURVEY

W. C. Mendenhall, Director

Professional Paper 198

\section{OCCURRENCE AND ORIGIN OF THE TITANIUM DEPOSITS OF NELSON AND AMHERST COUNTIES, VIRGINIA}

BY

CLARENCE S. ROSS

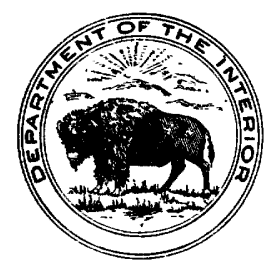

UNITED STATES

GOVERNMENT PRINTING OFFICE

WASHINGTON : 1941

For sale by the Superintendent of Documents, Washington, D. C. - - Price 25 cents (Paper cover) 
.

.




\section{CONTENTS}

Abstract

Introduction

General geology $\ldots \ldots \ldots$

Petrography ...............

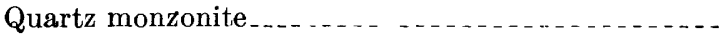

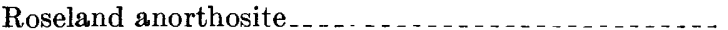

Primary andesine anorthosite...............

Granulated andesine anorthosite ............

Oligoclase anorthosite.

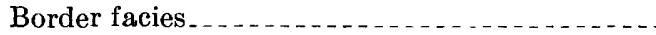

Pegmatitic and aplite zones ...............

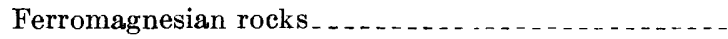

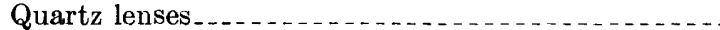

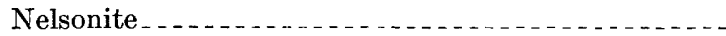

Definition

Distribution and occurrence...................

Ilmenite nelsonite

Rutile nelsonite.

Mineralogy

Antiperthitic andesine .........

Microcline...........

Rutilated quartz....

Clinohypersthene... . .

Clinozoisite........

Amphiboles. . . . . .

Micas_......

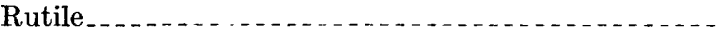

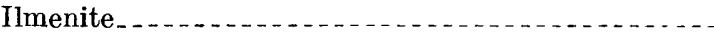

Sphene (leucoxene)

Magnetite

Apatite.

\begin{tabular}{|c|c|c|}
\hline ge & Mineralogy-Continued. & Page \\
\hline 1 & - & 14 \\
\hline 1 & Origin of the rocks and minerals & 15 \\
\hline 2 & Andesine anorthosite & 16 \\
\hline 3 & Oligoclase anorthosite & 17 \\
\hline 3 & Quartz lenses........ & 17 \\
\hline 3 & Border facies. & 17 \\
\hline 3 & Ferromagnesian dikes. & 18 \\
\hline 4 & Disseminated minerals & 18 \\
\hline 4 & Ferromagnesian lenses. & 19 \\
\hline 4 & Nelsonite & 20 \\
\hline 6 & Summary of evidence of origin & 22 \\
\hline 6 & Related titanium deposits & 23 \\
\hline 7 & St. Urbain, Quebec & 23 \\
\hline 7 & Magnet Cove, Arkansas & 23 \\
\hline 7 & Physicochemical processes controlling mineralization..... & 26 \\
\hline 7 & Theoretical background & 26 \\
\hline 9 & Stability of minerals & 26 \\
\hline 10 & Reaction principle & 27 \\
\hline 10 & Relation between alkalies and alumina........ & 27 \\
\hline 11 & Physical character of replacing solutions ....... & 28 \\
\hline 11 & Source of ferromagnesian materials & 30 \\
\hline 11 & Chemistry of replacement & 30 \\
\hline 11 & Source and character of the solutions & 33 \\
\hline 12 & Mode of segregation and transportation of mineral- & \\
\hline 13 & izing materials & 34 \\
\hline 13 & Phosphorus & 34 \\
\hline 14 & Titanium & 35 \\
\hline 14 & Iron, magnesium, and calcium & 36 \\
\hline 14 & Restatement of paragenesis_. & 37 \\
\hline 14 & Index & 59 \\
\hline
\end{tabular}

\section{ILLUSTRATIONS}

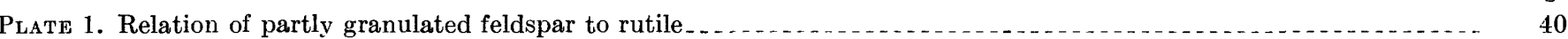

2. Replacement of feldspar by secondary minerals . .

3. $A, B$, Secondary minerals replacing feldspar; $C$, Antiperthite; $D$, Perthite

4. Secondary minerals in feldspar $\ldots \ldots$

5. $A$, Rutile in quartz; $B$, Actinolite replacing quartz; $C$, Replacement of feldspar by secondary minerals; $D$, Replacement of feldspar by rutile $\ldots$

6, 7, 8. Replacement of anorthosite by ferromagnesian minerals

9. Replacement of clinohypersthene by hornblende and by apatite

10. Augen injection gneiss in schist and its alteration products

11. Replacement of anorthosite by nelsonite

12. $A$, Replacement of anorthosite by nelsonite; $B$, Replacement of quartz by apatite

13. Amphibolite nelsonite replacing anorthosite and development of schist structure

14. $A, B, C$, Relation between ilmenite and apatite in nelsonite, $C$ showing residual areas of anorthosite; $D$, Clinohypersthene invaded by ilmenite

15. Replacement of anorthosite by nelsonite...........

16. $A$, Rutile and secondary minerals replacing anorthosite; $B$, Mineralized anorthosite injection gneiss . . . . . . . . .

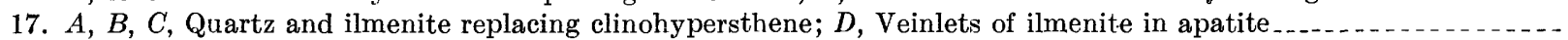

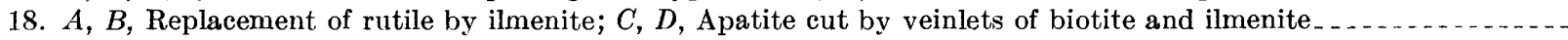

19. $A, B, C$, Replacement of rutile by sphene; $D$, Replacement of rutile by ilmenite and sphene Figure: 1. Map of the Virginia titanium region.

INSERT

Paragenesis of minerals from the Roseland titanium district, Virginia 



\title{
OCCURRENCE AND ORIGIN OF THE TITANIUM DEPOSITS OF NELSON AND AMHERST COUNTIES, VIRGINIA
}

\author{
By Clarence S. Ross
}

\begin{abstract}
The titanium deposits in the central part of Virginia, near the eastern base of the Blue Ridge, have long been the world's principal source of rutile and contain large supplies of ilmenite. The ores are associated with the Roseland anorthosite, a rock composed of antiperthitic andesine. This feldspathic rock mass is roughly elliptical in shape, covers an area of about 22 square miles, and intrudes a gneissic quartz monzonite that forms the dominant country rock of the region. The anorthosite shows crushing and granulation throughout the area, and only locally are there uncrushed residual masses, rarely more than 1 foot in diameter, of the coarse-grained primary feldspar. This clastic structure is similar to that in other anorthosite masses.

The titanium minerals occur in deposits of two distinct typesas disseminated deposits in the anorthosite and as veinlike or dikelike masses of a rock known as nelsonite, which is characterized by rutile and apatite or by ilmenite and apatite. Most of these masses are within the anorthosite, but a few are outside of it. Associated with the anorthosite are a few intrusive dikes and numerous ferromagnesian lenses that have replaced anorthosite along shear zones. The dikes are evidently offshoots of a deepseated intrusive mass, which is probably a ferromagnesian differentiate of the same primary magma whose other fraction is represented by the anorthosite.

The titanium minerals in both disseminated deposits and nelsonites were introduced after the granulation and consolidation of the anorthosite and are absent in the primary uncrushed feldspar. They are most abundant in the vicinity of shear zones, which evidently acted as feeding channels, and are associated with amphiboles, micas, clinozoisite, and quartz, which have replaced feldspar. The titanium and associated minerals are evidently the result of replacement and not of magmatic segregation or of pyrogenic processes.

The simple mineralogy of the feldspar rock that has been partly replaced and the small number of introduced elements present an unusually simple problem in the chemistry of replacement, and it has been possible to deduce chemical equations that are believed to represent closely the chemical processes in the different zones of mineralization. In the innermost zone $\mathrm{TiO}_{2}, \mathrm{FeO}$, and $\mathrm{MgO}$ were the essential components introduced. In the next zone $\mathrm{FeO}$ was deficient, and $\mathrm{TiO}_{2}$ and $\mathrm{MgO}$ were introduced. The outermost zone is characterized by the alteration of feldspar to clinozoisite and muscovite, but this has taken place without essential changes in the chemical composition of the replaced rock.

The geologic and mineralogic relations in the Roseland district show that $\mathrm{TiO}_{2}, \mathrm{FeO}, \mathrm{MgO}$, and at most small amounts of $\mathrm{CaO}$ and $\mathrm{K}_{2} \mathrm{O}$ were introduced by invading solutions in the order of succession listed. The acid radicals that accompanied these were $\mathrm{P}_{2} \mathrm{O}_{5}, \mathrm{~F}$, and a little $\mathrm{CO}_{2}$ and $\mathrm{Cl}$. An interpretation of this sequence in the light of physicochemical laws seems to indicate that the $\mathrm{P}_{2} \mathrm{O}_{5}$ and $\mathrm{F}$ of apatite (the earliest mineral of the group) were segregated from the parent magma by a distillation. $\mathrm{CaO}$
\end{abstract}

may not have been an essential part of this vapor phase but was derived largely from local supplies in calcic feldspar.

At a slightly later stage $\mathrm{TiO}_{2}$ was distilled over as a ve.bor phase of titanium tetrafluoride. The ferrous iron of ilmenite was in part derived from local ferromagnesian minerals, but part of it escaped from the parental ferromagnesian rock as a liq ?idphase hydrothermal solution, possibly as ferrous halogens or bicarbonate. This affords a method for the segregation and the sequence of $\mathrm{TiO}_{2}$ and $\mathrm{FeO}$ and explains how a high concentration of titanium may be derived from a normal ferromagnesian rock in which iron is dominant over titanium. The magnesium of the ferromagnesian silicates and the calcium of sparse calcite vrere probably segregated by the same process as the ferrous iron

The minerals of the anorthosite and the secondary minerals formed by its replacement are described.

\section{INTRODUCTION}

The titanium deposits of the Roseland distrist, Nelson and Amherst Counties, have long supplied most of the rutile used in the world, and the district also contains important deposits of ilmenite. These deposits show two modes of occurrence-one as disseminations in a feldspar rock and the other as lenticular veins or irregular dıkelike bodies, which commonly cut this same rock. This paper describes these titanium deposits and the rocks associated with them and discusses their paragenesis.

Statistics are not available on the production of rutile in this country but in 1937 the production v'as estimated to be about 2,000 tons, the greater part of which came from the Roseland district, in which the American Rutile Co. is the only producer. Recently the Hot Springs district of Arkansas has begun to produce. Norway has long been the only other producing country, and its yearly output has commonly been less than 100 tons, but Brazil is now exportng rutile. Only a few of the large bodies of ilmenite in the Roseland district have been systematically developad, and in the past most of the production has been ir sidental to the recovery of rutile. The Southern Mineral Products Corporation is now mining ilmenite from one of the larger ilmenite bodies, and the material is being used in the manufacture of titanium pigments.

The titanium deposits of Virginia have been descrit ad by Watson and Taber ${ }^{1}$ in an excellent report, which

1 Watson, T. L., and Taher, Stephen, Geology of the titanium and apatite deposits of Virginia: Virginia Geol. Surrey Bull. III-A, p. 3198, 1913. 
should be consulted by those interested in the general geology of the region or a detailed description of the occurrences; and that report has been a great help in the preparation of this paper. The present study has been made possible largely through the courtesy of the American Rutile Co., especially of Mr. J. H. Morley, mining engineer in charge of operations, and the officials of the Southern Mineral Products Corporation.

The Roseland district lies in the Piedmont region of Virginia, where it merges into the foothill region of the Blue Ridge. (See fig. 1.) The area is about equally

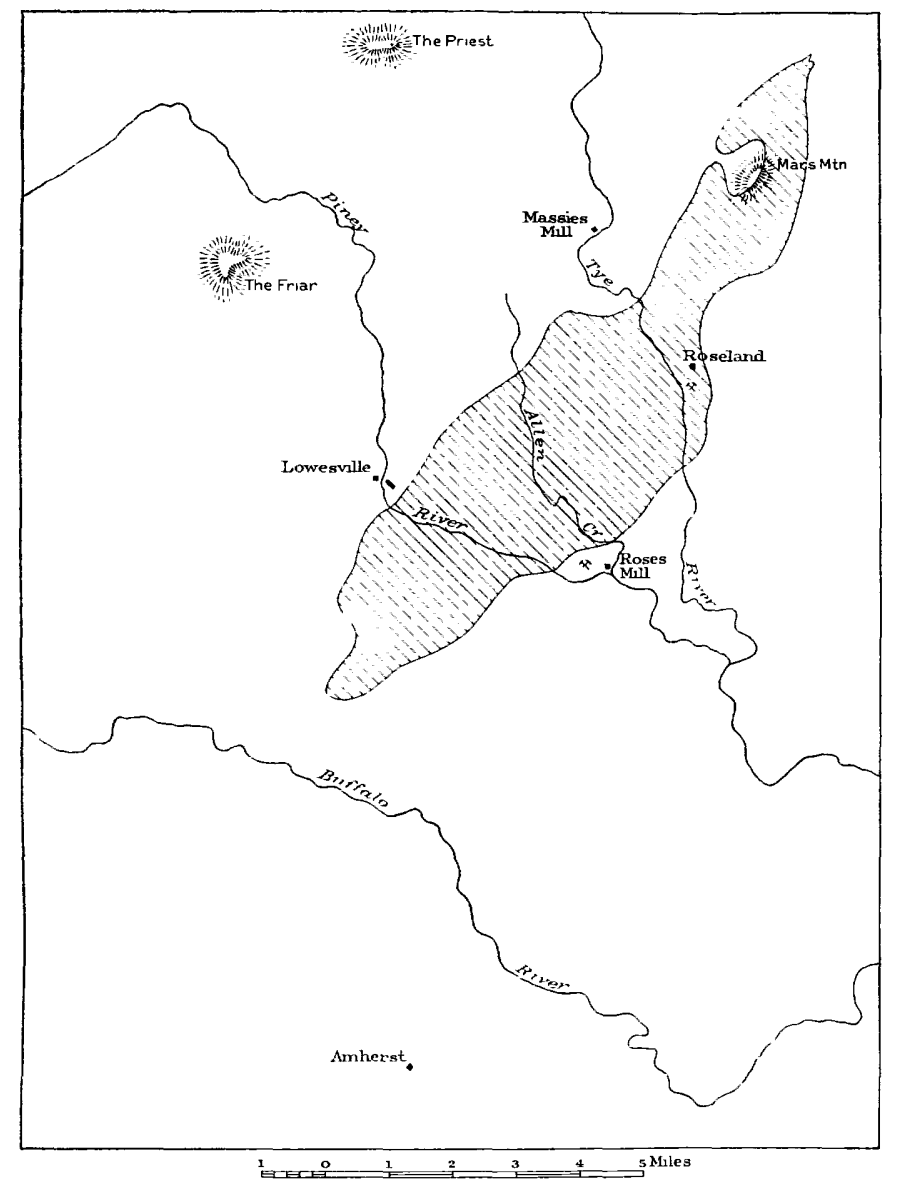

FIgURE 1.-Map of the Virginia titanium region. Ruled area shows position of anorthosite body.

distant from Charlottesville and Lynchburg, Va., and is crossed by the main highway between those cities. The main line of the Southern Railway is 5 to 7 miles to the southeast, and the nearest stations on that line are Arrington and Tye River. The area is drained by the Piney and Tye Rivers, which join the James River about 12 miles southeast of Roseland. The altitude of the immediate region ranges from about 700 feet on the Tye River to about 1,200 feet near the northeast part of the area, and the average altitude is about 800 feet. The crest of the Blue Ridge lies about 12 miles to the northwest, but the highest peaks of the region are about 6 miles east of the main ridge and rise to a height of about 4,000 feet. These outlying peaks are composed of a highly resistant gneissic quartz monzonite.

\section{GENERAL GEOLOGY}

The geologic setting of this part of Virginia has been described by Watson and Taber ${ }^{2}$ and need be outlined only briefly. The prevailing rocks of the region are gneisses and schists of pre-Cambrian age. The dominant rock of the Roseland district has been named the Lovingston granite gneiss, although described on the State geologic map ${ }^{3}$ as a biotite-quartz monzonite augen gneiss. It is part of a zone of intrusive rocks that extends from the vicinity of Warrenton on the northeast to Roanoke on the southwest, a distance of nearly 200 miles. The highest peaks of the adjacent rarts of the Blue Ridge and rugged hill areas of the nearby Piedmont region are formed by this rock.

Locally a fine-grained gneissic or schistose rock, which is evidently a metamorphosed sedimentary material, is present. It commonly contains augenlike lenses of microcline. (See pl. 10.) The pre-Cambrian geology of this part of Virginia presents many difficult and still unsolved problems, and the affiliations of this fine-grained gneiss or schist have not been determined. It may represent local lenses of the Lynchburg gneiss, or perhaps more probably of some other highl' metamorphosed sedimentary rock. The main body of the Lynchburg gneiss lies east of the quartz monzonite (Lovingston granite gneiss), and no part of it has been definitely traced into the Roseland district.

The so-called Lovingston granite gneiss is a rather variable rock but is in general best described as a gneissic, biotite-rich quartz monzonite and will be referred to as the quartz monzonite in this paper. The igneous character has not been greatly modified during the development of the gneissic structure. The most marked alteration observed has been along the border of the Roseland anorthosite, where it has been intruded by feldspathic material.

The quartz monzonite was intruded by a feldspar rock here called the Roseland anorthosite. This rock is also believed to be pre-Cambrian in age, although distinctly younger than the rocks it intrudes. The length of this intrusive mass is about 13 miles, the greatest width about $2 \frac{1}{2}$ miles, and the totaJ area about 22 square miles. The elongation is to the southwest and coincides with the general structure of the region. A large inlier of quartz monzonite occurs near the northeast end of the intrusion and is marked by Mars Mountain, which rises several hundred feet above the surrounding area of anorthosite. The bourdary of the anorthosite as mapped by Watson and Taber (see fig. 1) is only approximate in places, owing to concealment by a deep mantle of residual soil or to a broad transi-

${ }^{2}$ Idem, pp. 5ti-59.

3 Geologic map of Virginia, Virginia Geol, Survey, 1923. 
tional zone between the anorthosite and the enclosing rocks.

The Roseland anorthosite is cut by numerous quartz veins, dikes rich in ferromagnesian minerals, and large lenticular bodies of a rock called nelsonite.

The Roseland district lies in a region of very deep weathering, and except in areas of rugged relief the rocks are weathered to depth of 30 feet or more. Good outcrops are observable only along the streams and in a few places where they have been exposed by mining operations. The Roseland anorthosite has weathered more readily than the enclosing quartz monozonite. Consequently the anorthosite has been reduced to a nearly plane surface, somewhat dissected as a result of recent uplift, whereas the more resistant quartz monzonite tends to form rugged hills that range from a few hundred to more than 1,000 feet in height in the foothill region and attain a height of 4,000 feet in the Blue Ridge. The nearly pure feldspathic rock weathers to a kaolinitic soil, which may be nearly white a few feet below the surface; but its iron-rich zones and the enclosing schists and gneisses weather into a red soil.

\section{PETROGRAPHY QUARTZ MONZONITE}

In the course of this investigation the quartz monzonite has been studied only where closely associated with the titanium ore deposits. For that reason its general character can be best presented by quoting from the description given by Watson and Taber: ${ }^{4}$

The outside or country rock of the rutile-ilmenite-apatite area is a pronounced foliated, quartz-biotite gneiss, which shows in many places a considerable development of schists of variant composition. Gneiss is the dominant type in this complex of metamorphic rocks and has wide general distribution beyond the limits of the area mapped throughout the Blue Ridge region of central western Virginia. $* * *$ The gneiss has a pronounced banded or schistose structure and exhibits considerable textural and mineralogical variations, but the prevailing kind is a medium to dark-gray rock varying from a fine to medium-coarse, evengranular to porphyritic texture, the rock having in the latter case a distinct augen-gneiss appearance. $* * *$ The principal minerals recognizable with the naked eye are feldspar, quartz, and biotite. Ilmenite and muscovite and rarely hornblende are also apparent in some specimens. Ilmenite is frequently concentrated in the sands derived from the decay of the gneiss. Some of the black grains composing the sand are magnetic and are probably magnetite. Biotite is frequently altered to chlorite, and in the vicinity of the gneiss-syenite contact much of the quartz in the gneiss is pale blue in color, resembling that of the syenite.

Near the contacts with the anorthosite the quartz monzonite shows varying degrees of alteration and introduction of secondary minerals. The most conspicuous of these minerals is blue rutilated quartz, but titanium minerals, and especially sphene have also been introduced. Along the borders, especially near Rose Mills, there is a wide transitional zone between quartz

\footnotetext{
4 Watson, T. L., and Taber, Stephen, op. cit., p. 201.
}

monzonite and anorthosite, described in detail on pages 4 and 5 .

\section{ROSELAND ANORTHOSITE}

The Roseland anorthosite was called pegmatite by Merrill. ${ }^{5}$ Watson and Taber ${ }^{6}$ described it as a syenite, although they point out that the dominant feldspar is plagioclase (andesine) rather than a potash feldspar and suggest, in a footnote, that perhaps anorthosite would be an appropriate name. ${ }^{7}$ On the geologic map of Virginia the anorthosite is mapped as albitite. Syenite is not a suitable name, as potassium feldspar is subordinate to plagioclase. The rock was originally made up of very coarse feldspar crystals (see p].1), but granulation has given it a marked variation in texture. The rock originally had a pegmatitic habit, if "pegmatitic" is used only to describe an unusually coarse-grained rock. However, it has not the dikelike form of many pegmatites, its granulation has destroyed the coarseness of grain in much of the area, and the suggestion that it has genetic affinity with anorthosites rather than with normal pegmatites seems strong. The Roseland anorthosite seems to have been intruded in the same manner as the anorthosites of the Adirondack region of New York. Very marked coarseness of grain, partial granulation, antiperthitic feldspars, and associated titanium minerals characterize many anorthosites. This feldspar rock of the Roseland district is therefore designated anorthosite in this paper, although it is somewhat more sodic than many anorthosites.

The similarity of the Roseland anorthosite to anorthosites from other localities has been pointed out by Watson and Taber ${ }^{8}$ and by Bowen and Buddington, ${ }^{9}$ who are both familiar with the anorthosites of the Canadian Shield region.

\section{PRIMARY ANDESINE ANORTHOSITE}

The primary rock of the andesine facies of the anorthosite is represented by the ungranulated arens of feldspar that may be observed in many outcrops, but it was best studied in the open-cut mine of the American Rutile Co., near Roseland, but later mining operations have removed the best of this material. Here the primary feldspar forms light bluish-gray ungranulated residual areas, as distinguished from the nearly vhite granulated feldspar. These residual areas are as ruuch as 10 to 20 centimeters in diameter and were evidently even larger before partial granulation. The relations between the primary feldspar masses and the granulated parts are shown in plate 1 . When exarrined closely the primary andesine shows a satiny appearance, owing to the presence of minute lenses of microcline.

\footnotetext{
${ }_{5}$ M Lerrill, G. F', Rutile mining in Virginia: Eng, and Min. Jour., vol. 78, p. 35, 1902.

6 Watson, T. L., and Taher, Stephen, op. cit., pp. 68-90

7 Idem, p. 79

8 Idem, $p$.

9 Bowen, N. L., and Budainston, A. F., personal communications.
} 
The andesine with its intergrown microcline (see pl. $3, C)$ appears to have been almost the only primary mineral present in the original rock. This ungranulated primary feldspar is nearly free from secondary minerals, which have formed only locally along shear fractures that cut across many of the residual masses, as shown in plates 1 and 2. An analysis of a sample of primary feldspar (p. 10) shows that it is composed of about 25 percent of microcline, 51 percent of the albite, and 24 percent of the anorthite molecules. A recalculation of the plagioclase indicates that it has a composition of $A b_{68.5}$.

\section{GRANULATED ANDESINE ANORTHOSITE}

All parts of the anorthosite mass show crushing and granulation, so that millimeter-sized grains, though irregularly distributed, make up a large portion of the rock. There appear to have been distinct zones of maximum crushing, so that areas of almost complete granulation alternate with very irregular areas where the rock has been fractured but less thoroughly granulated.

The granulated parts of the anorthosite are nearly pure white, except where darkened by the introduction of clouds of secondary minerals, as shown in plate $2, A$. However, the abundance of these secondary minerals cannot be judged in the hand specimen, as large amounts of tremolite, muscovite, and clinozoisite have commonly developed in rocks that are white and have remained fresh in general appearance. The microscope shows an aggregate of feldspar grains that are extremely irregular in size, as in a single slide they may range from 0.01 to 1.5 or 2 millimeters in diameter. (See pl. $2, D$.) They are also irregular and ragged in outline, and all but the smallest grains show evidence of strain by the presence of undulatory extinction. Commonly, ungranulated feldspar shows marked strain on the contact with granulated material. (See pl. 2, D.) Most of the grains show the same type of antiperthitic inclusions of microcline as the primary ungranulated feldspar, described in the previous section. Only an occasional grain and rare border areas on other grains are without antiperthitic inclusions.

The granulated feldspar is in general andesine of the composition $A b_{64}$ to $A b_{70}$, but a small proportion is oligoclase, or albite as high as $A b_{93}$. Some rare disseminated grains of albitic plagioclase are free from antiperthitic intergrowths and probably represent primary crystallization of a late alkalic magma residue; however, the presence of antiperthite in most of the albite grains indicates albitization of earlier andesine.

A very small amount of quartz fills interspaces between some of the feldspar grains. It is free from the inclusions of rutile needles that characterize the bluegray quartz associated with the replacing lenses of ferromagnesian minerals. Most analyses of andesine anorthosite show a small percentage of normative quartz as shown by the analyses, given by Watson ard Taber. ${ }^{10}$ A very few small grains of limpid potassium feldspar are also present in the andesine anorthosite, and evidently belong to the same stage in the formation of that rock as the interstitial quartz. No part of the granulated anorthosite seems to be entirely free from secondary minerals, and in much of the rock they are very abundant. These minerals are rutile, ilmenite, sphene, biotite, muscovite, actinolite, tremolite, and clinozoisite. In a few specimens they occur as small lenses or veinlets, but in general they form swarms of microscopic size within feldspar grains.

\section{OLIGOCLASE ANORTHOSITE}

The tunnels of the American Rutile Co., lave penetrated a mass of gray, nearly equigranular oligoclase anorthosite which locally borders the andesine anorthosite. The individual mineral grains average about 0.5 millimeter in diameter, but the grain of the rock appears to be coarser because light and dark minerals are grouped in aggregates 2 to 3 millimeters in diameter.

A microscopic study shows that the rock is composed largely of antiperthitic oligoclase $\left(A b_{80}\right)$, which has been partly replaced by secondary minerals, as described on page 17. Small amounts of rutile-free quartz and potassium feldspar form filmlike areas around oligoclase, as described on page 10 . Secondary mineralization has altered primary pyroxenes to amphiboles and introduced abundant rutilated blue quartz, micas, and clinozoisite. This rock is more sodic than the andesine phase, but the associated minerals and their relations are similar, and the rock appears to have been composed originally of antiperthitic feldspar and pyroxenes.

The contact between the anorthosite and the enclosing rock is commonly marked by an injection gneiss formed by the introduction of feldspathic material along schist planes. The best example of this contact is on the southeast border near Rose Mills, where a transitional zone about 500 feet wide is well exposed in the bed of Allen Creek and in a gully near the roadside. The transitional facies is a gneissoid zone, made up of anorthosite lenses that parallel the schistosity and alternate with other lenses almost free from anorthosite. These anorthosite lenses become prcrosessively fewer and narrower with increasing distance from the contact.

The lenses of anorthosite in the gneissic rock range from mere stringers to lenses several feet across. In the hand specimen they show a feldspar matrix that contains large but variable amounts of secondary minerals. (See pl.16, B.) These are arranged in roughly parallel lenses that coincide with the schistosity of the enclosing schist and give the rock a roughl rr gneissic structure. These secondary minerals are dark-colored

\footnotetext{
${ }_{10}$ Watson, T. L., and Taber, Stephen, op. cit., p. 78.
} 
silicates, blue quartz, rutile, and a little ilmenite. Microscopic study shows that the feldspar is largely oligoclase that has a composition of about $A b_{80}$ and so is slightly more sodic than the andesine of the main mass of the anorthosite. In some lenses this is largely antiperthitic, but in others a large proportion is free from antiperthitic microcline. This part is in general much less replaced by secondary silicates than the antiperthitic material. The fresher type of feldspar is surrounded by a narrow reaction rim of microcline.

The blue quartz forms grains 3 centimeters in maximum length that tend to be elongated in the direction of gneissic structure (see pl. 16, B). They have rounded borders but are markedly lobate in outline. Some lenses of anorthosite contain irregular lenses of material which was originally clinohypersthene that formed along shear zones This material is now completely altered to a fibrous hornblende aggregate. Swarms of secondary silicates have formed abundantly in the feldspar. These commonly fill most of an antiperthitic feldspar grain, but elsewhere they are localized along fractures in feldspar. The order of formation of minerals is as follows: Antiperthitic feldspar, perthite-free plagioclase, reaction rim of nicrocline, clinohypersthene, quartz, apatite, rutile, ilmenite, and the disseminated hornblende, sericite, biotite, and clinozoisite. The relation of quartz to clinohypersthene is not evident, and the disseminated minerals evidently formed together. Calcite appears to have been the last mineral to be formed.

The lenses of schist or gneiss that alternate with anorthosite are all indurated and much more resistant to erosion than the normal rocks of the immediate area. A microscopic study indicates that the material was originally a quartz schist with lesser amounts of microcline, oligoclase, and biotite. Feldspar lenses or augen of microscopic size, related to the anorthosite, have been introduced into this material, and this was followed by the introduction of secondary minerals. Some lenses are largely quartz with secondary biotite; others show zones of almost pure epidote. In general, the schist lenses are made up of partly recrystallized primary schist material, introduced feldspar, and secondary biotite, epidote, clinozoisite, actinolite, ilmenite, leucoxene, and more rarely garnet. One specimen from the same locality appears to be a lens of quartz monzonite, rather than quartz schist.

A specimen of injection gneiss was obtained near the contact with the north border of the anorthosite mass, which is exposed about 1 mile southeast of Massies Milland again in a road cut a few rods east of the Massies Mill School. (See pl, 10.) This material has intruded a local mass of fine-grained schistose rock that is evidently metamorphosed sedimentary material. Mrs. Anna J. Stose ${ }^{11}$ reports that such schistose lenses

\footnotetext{
11 Personal communication.
}

are commonly intruded by microcline augen gneirs in adjacent parts of Virginia, and so this injection gneiss is probably older than the material at Rose Mills and the nearby aplitic lenses. However, it has beer replaced by secondary minerals similar to those at Rose Mills. A microscopic examination of the injectionfree fine-grained schist shown at the left of plate 10 shows that it is composed of about equal parts of quartz, feldspar (largely microcline), and biotite. It also contains small amounts of amphiboles, clinozoisite, and sphene. These have also formed in the intrusive feldspar lenses and so are later than the primary schist material.

This fine-grained schist material was intruded by feldspathic material, and most of the specimen is an injection gneiss composed of large, nearly white feldspar augen enclosed in dark contorted schist material that bends around them. The augen are dominantly microcline but contain oligoclase as disseminated grains and perthitic lenses. The microcline has been pertly replaced by large areas of coarse-grained myrmekite, a plumose intergrowth of quartz and oligoclase.

Subsequent to the introduction of the microcline the rock was sheared, producing schistose zones, which cut across or more commonly bend around the microcline augen. Diagonal fractures were also developed within the microcline areas and make an angle of about $45^{\circ}$ with the prevailing direction of schistosity, and minor amounts of secondary minerals were formed along these fractures. The augen gneiss now contains two distinct types of schistose material. One is the original schist that has been distorted and recrystallized during the introduction of the microcline, and the other is a product of later shearing and alteration of both microcline and schist. In plate 10 the older schist shows as darkcolored areas. The areas of later shearing are light gray, and many of them cut through a single feldspar grain. The later schistose areas (those that appear light gray) are composed almost exclusively of muscovite, formed mainly by the shearing and alteration of feldspar but to a lesser degree by shearing of areas of the older schist. The plagioclase of the disseminated grains, the myrmekite, and the perthitic lenses has all been replaced by an aggregate of clinozoisite and sericite, leaving the microcline nearly fresh. Ilmenite, sphene, very finely disseminated rutile, apatite, and blue quartz were introduced along these shear zones. The late introduction of ilmenite and sphene is shown by the absence of fracturing in these minerals, despite the extensive shearing the rock has undergone. Apatite is very slightly broken but shows no evidence of grenulation. The augenlike areas of blue quartz have k aen strained and slightly sheared but are not granulated. The ilmenite has been almost completely altered to leucoxene in some areas, but in others only narrow flms of leucoxene have formed. 


\section{PEGMATITIC AND APLITE ZONES}

The anorthosite is cut by small narrow lenses whose minerals seem to be allied to pegmatites, and aplites. Pegmatitic material is shown in a quarry operated by Dominion Minerals, Inc., on the Piney River about a mile northwest of the point at which the Charlottesville-Lynchburg road crosses that stream. Here the anorthosite is cut by numerous parallel shear zones that have been a site for extreme alteration of the anorthosite to amphiboles, micas, and clinozoisite. Other zones only a few centimeters in width contain minerals of a pegmatitic character.

One specimen contains microcline, muscovite, oligoclase, and quartz, named in the order of their abundance. Minor minerals are clinozoisite and apatite associated with muscovite in irregular veinlike areas. The microcline is nearly fresh, but the plagioclase shows the usual alteration products-muscovite and clinozoisite. These plagioclase areas seem to be remnants of replaced anorthosite, but the grains are commonly surrounded by narrow zones of slightly more sodic oligoclase that is almost free from alteration. Seemingly a little fresh material has been added to these grains subsequent to their partial replacement and alteration. The microcline contains varying proportions of perthitic albite. The quartz sends veinlets and rounded lobes into areas of feldspar and is clearly later than these minerals but may be of approximately the same age as the muscovite. No titanium minerals were observed in the pegmatitic lenses.

Other lenses in this locality are composed of an aplitic rock. One sample is dominantly microcline with less oligoclase and quartz, and another is largely oligoclase. Associated with these lenses are others composed of a very fine grained aggregate in which clinozoisite is the dominant mineral, but with a little colorless garnet, veinlets of quartz and a little pyrite.

The immediate contact is not well exposed along the north border of the anorthosite mass, but a road cut at the Massies Mill School lies near this contact. Lenses of material that is related to the anorthosite intrude the schistose country rock. These are small dikes as much as 10 centimeters in width. They are composed of white feldspar, lenses of blue quartz, and a few grains of rutile. The microscope shows a rock composed largely of perthitic microcline. The perthite grains are about 1 millimeter in diameter and are surrounded by a zone of nonperthitic microcline, albite, and quartz. The rock is less altered than the anorthosite, but the same group of minerals have formed, and clinozoisite and sericite are especially abundant. The rock is potassic rather than sodic, as is the anorthosite, and it is therefore not a small dike of anorthosite but probably an aplitic differentiate of that rock. The abundant blue quartz, the similar alteration, and the disseminated rutile indicate its close relationship to the anorthosite. The quartz forms clear-cut veinlets, which follow the cleavage planes in the microcline, as illurtrated in plate $3, D$.

\section{FERROMAGNESIAN ROCKS}

Several small, sharp-walled dikes have been encountered in the tumnels of the American Rutile Co. Some of them are very fine grained, and others are moderately coarse, but no abyssal rock types have been observed. The fine-grained dikes are commonly only a few centimeters across, and at least one is much branched. They are now highly altered, ard only an approximate determination of their original composition is possible. However, they were evidently highly ferromagnesian rocks composed dominantly of pyroxene with subordinate feldspar. In one specimen the pyroxene has been completely altered to a very finegrained aggregate of amphiboles and biotite. Little or no feldspar remains, the rest having been replaced by amphiboles, biotite, epidote, and quartz. Another specimen contains a smaller proportion of a palercolored amphibole, and biotite and a larger proportion of low-iron epidote and probably represents a rock originally richer in feldspar. All specimens contain small amounts of apatite, ilmenite, and sphene.

A large dike is a conspicuous feature of the mine of the American Rutile Co. This dike is absut 8 feet wide, is nearly vertical, and strikes $\mathrm{N} .25^{\mathrm{c}} \mathrm{E}$. It is massive, very fine-grained and dense in texture. It appears superficially to be much fresher than the ferromagnesian dikes above described but l'ns undergone the same type of alteration. A microscopic study shows that the original rock minerals (plagioclase and augite) have been almost completely replaced by clinozoisite, fibrous amphiboles, biotite, and chlorite. The dike contains numerous areas of pyrite and a dustlike material that is probably ilmenite. It is cut by numerous small pegmatitic veins 1 to 4 contimieters wide, which are composed essentially of quartz, orthoclase, and calcite. Smaller amounts of pyrite, pyrrhotite, and chalcopyrite are present. Most of these pegmatitic veins contain numerous angular inclusions of the enclosing dike rock. A microscopic eramination shows that most of the inclusions have nearly the same mineral composition as the dike rock, although some of the smaller ones have been somewhat recrystallized. Between the inclusions and the pegmatitic feldspar there is a reaction zone in which radial groups of chlorite and clinozoisite crystals have developed. Locally apatite is very abundant. Calcite is also present and is later than feldspar and quartz and probably formed at about the same time as the sulfides with which it is associated.

Watson and Taber ${ }^{12}$ applied the name "gabbro" to rocks characterized by feldspar and lenses of pyroxene - a name which implies a primary pyrogenic origin. Some ferromagnesian facies of the anorthosite may have

\footnotetext{
${ }_{12}$ Watson, T. L., and Taber, Stephen, op. cit., pp. 191-192.
} 
had such an origin, but the type of material that is well represented in the mine of the American Rutile Co. seems to have originated in a different way. These ferromagnesian lenses are composed of the pyroxene clinohypersthene, described on page 11 , and its alteration products. They are believed to consist of a secondary material that has replaced feldspar, and so their origin will be discussed in the section on origin rather than in this section.

\section{QUARTZ LENSES}

Quartz that is commonly blue or gray occurs as lenses or veinlike masses, which are locally present throughout the anorthosite area. These bodies seem to be most abundant in areas of marked alteration of the anorthosite and are especially abundant where there is a large concentration of ferromagnesian minerals, as in the workings of the American Rutile Co. at Roseland. Quartz is abundant on the Bryant farm, where it is associated with rutile. Quartz also occurs in lesser amount in areas of only minor mineralization as rather narrow, sharp-walled veins cutting anorthosite.

\section{NELSONITE}

\section{DEFINITION}

The Roseland district is the type locality for a rock composed essentially of apatite and rutile, or apatite and ilmenite, which Watson ${ }^{13}$ called nelsonite, after Nelson County. The following varieties of nelsonite have been listed by Watson and Taber: ${ }^{14}$ Ilmenite nelsonite, rutile nelsonite, magnetite nelsonite, biotite nelsonite, hornblende nelsonite, and gabbro nelsonite.

\section{DISTRIBUTION AND OCCURRENCE}

In describing the distribution of the nelsonite bodies Watson and Taber ${ }^{15}$ say:

The nelsonite dikes usually occur not far from and distributed along the border portion of the syenite (anorthosite), with most of them confined to the syenite area, but some are found in the outside gneiss near the contact. The rutile-bearing variety of nelsonite is confined within the limits of the syenite, but the ilmenite nelsonites free from rutile, which are more numerous within the syenite area, are found in the outside gneiss near the contact.

Magnetite nelsonite is found in the surrounding gneiss, but does not occur in the syenite.

The size and shape of the bodies are described as follows: ${ }^{16}$

The size of the dikes varies greatly. Several of the more persistent ones may be traced along their strike for considerable distances. In length the dikes range up to 2,000 feet, as exposed on the surface, but lengths of several hundred feet are more common; in width from a few inches up to 65 feet or more.

${ }^{13}$ Watson, T. L., Mineral Resources of Virginia, J. P. Bell, Lynchburg, Va., p. 300,1907 .

It Watson, T. L., and Taber, Stephen, Geology of the titanium and apatite deposits of Virginia: Virginia Geol. Survey Bull. III-A, p. 104, 1913.

${ }^{15}$ Idem, p. 101

${ }^{16}$ Idem, p. 102.
Though dikelike in character, the nelsonite bodies are s'ibject at times to considerable irregularity in outline. Sevenal of them are lenticular in shape, and where the more continuous bodies have been exposed for some distance they are found to pinch and swell both in dip and along the strike. In some instances the dikes before pinching out split into several parallel stringers. They trend in every conceivable direction, but northeast and southwest is the dominant direction of strike.

Usually the boundaries between the dikelike bodies of nelsonite and the enclosing rock are sharply marked, but in places there is a gradation between the two, which is especially true of the rutile nelsonites.

A few of the nelsonite bodies are simple in mineralogy, being composed almost wholly of apatite and ilmenite or rutile; but other varieties are made up of a number of minerals and are extremely variable in mineral composition within short distances.

The type of ilmenite nelsonite known as "hard ore" is composed dominantly of ilmenite and apatite, with only minor amounts of accessory minerals. The apatite is conmonly rounded and embayed, as in the rutile nelsonite, and appears to be slightly older then ilmenite, as rare vemlets of ilmenite fill fractures in it. (See pls. $14, A$, and $17, D$. ) A specimen of ilmenite nelsonite obtained half a mile west of Rose Union, with almost no accessory minerals, contained 73 percent of ilmenite and 27 percent of apatite by weight and is illustrated in plate $14, B$. The hard ore type of nelsonite is commonly the only one resistant to weathering and so forms abundant float material. Thus it appears from the surface indications to be more abundant than other types, although this is not true for most of the deposits. A type of hard ore with small amounts of biotite and actinolite forms the large ilmenite body controlled by the National Lead Co. on the Bob Hite farm, about 1 mile northwest of Roseland, and a representative sample has approximately the following mineral composition by weight: Ilmenite, 64 percent; apatite, 27 percent; biotite, 5 percent; actinolite, 4 percent. The biotite fills veinlets and fractures in ilmenite and apatite. (See pl. 18, C, D.) Some of this biotite forms very fine aggregates, but a few individual grains reach 0.5 millimeter in diameter. Another specimen from the same locality contains sbout 20 percent of biotite.

The best exposure of ilmenite nelsonite available for detailed study is that of the Southern Mineral Products Corporation on the Piney River near the southeast border of the anorthosite mass. Here extensive opencut mining has given a section across one of the largest ilmenite bodies of the region. Operations except for prospect shafts are still confined to the zone of weathering, but some of the harder lenses are fairly fresh. It has been possible to make thin sections of even the most weathered material and determine the minerals and their relations. These show that weathering has resulted less in chemical than in mechanical breakdown of the minerals. 
The materials of this ilmenite body are extremely variable, and the character of the different lenses may change abruptly or may be transitional over many feet. A schistose structure is noticeable in much of it (see pls. $13, D$, and 15, $C, D$ ) and seems to indicate development in a rock that had been closely sheared. Some of the more abundant types of material are described below and indicate the extreme variability in mineral composition.

Part of the body is composed largely of ilmenite and alteration products of apatite and makes a hard ore that forms a resistant float on the surface. Small amounts of magnetite fill minute cracks in ilmenite and are evidently later than the ilmenite.

Another specimen contains minor proportions of ilmenite enclosed in a groundmass made up largely of wisplike areas of partly altered biotite, which are roughly oriented, giving a schistose structure, as shown in plate $15, D$. The biotite has been partly altered to greenish chlorite. A small amount of actinolite is present, and many areas of quartz have been partly replaced by biotite and actinolite. A nearly similar rock has areas of chlorite 10 to 15 millimeters long that extend in the direction of schistosity except where molded around apatite or ilmenite grains. Other areas are composed largely of actinolite, which is commonly associated with small amounts of unreplaced quartz.

A related type of material contains a few areas of partly replaced andesme, as shown in plates $14, C$, and 15 , but most of the feldspar has been completely replaced by a fine-grained aggregate of biotite, quartz, and fibrous actinolite. Some of the biotite areas retain a ghostlike structure derived from the lamellar antiperthite of replaced plagioclase. Other areas of fibrous actinolite appear to represent completely altered pyroxene grains. A light reddish-brown type of hornblende has been partly altered to greenish hornblende, and fresh green hornblende that forms euhedral or subhedral crystals is abundant. Biotite is most abundant as fine-grained aggregates, but individual grains are also present and reach a maximum diameter of 1 millimeter. These have been partly altered to chlorite.

A friable reddish-brown material is composed of sparse ilmenite and apatite grains in an earthy groundmass. A microscopic examination shows about 15 percent of ilmenite and 13 percent of apatite by weight, in a groundmass composed of very finely granular biotite and its vermiculitelike alteration products. A small amount of partly replaced quartz is present, but the original feldspar has been completely replaced by biotite. Biotite fills numerous small veinlets in the apatite and is therefore later.

One lens has a friable, earthy appearance and carries only a few percent of apatite and ilmenite. A microscopic study shows that the rock is made up dominantly of very fine-grained actinolite with varying proportions of fine grained interstitial biotite and locall-r quartz. Some areas still retain andesine, which has been only partly replaced by secondary minerals, as shown in plate 15.

A prospect pit has penetrated unweathered hornblende nelsonite that is dark gray-green. It is strongly schistose, with a silky luster on the cleavage surfaces, due to the parallel orientation of the hornblonde and chlorite grains. A microscopic study shows that the most abundant mineral is hornblende, whi?h forms parallel groups that are molded around apr.tite and ilmenite grains and augenlike aggregates, as illustrated in plate $13, D$. A few of these augen retain the albite twinning of the original feldspar, as shown in plate $15, C$, but in most of them the feldspar has been recrystallized into fine grained augenlike aggregates of albite, quartz, and hornblende that are bounded by the enclosing zones of hornblende. Other specimens of the same material contain compact masses of fibrous hornblende that is an alteration product of augite. A few areas of biotite partly altered to chlorite are commonly present. Apatite is cut by small veinlets of ilmenite, and both apatite and ilmenite by veinlets of hornblende. A small percentage of pyrite is associated with ilmenite.

A small lens of anorthosite that occurs in the nelsonite body shows the beginnings of the replacement that when carried to completion produced the augen structure in the nelsonite just described. The rock is composed largely of plagioclase showing albite twinning but lacks the antiperthitic microcline that characterizes most of the anorthosite. The rock eivdently contained a small proportion of augite, which is now a hornb ende aggregate. The plagioclase has been partly replaced by hornblende, as shown in plate $4, D$. Parallel swarms of hornblende needles have formed and show traces of the schistosity that is greatly accentuated in the nelsonite. In a few areas the plagioclase has recrystallized into an aggregate of quartz, albite, and hornblende, as in the augen of the nelsonite. Small amounts of ilmonite and apatite have been introduced along shear zones. Other specimens of highly altered anorthosite found near the contact with nelsonite show more nearly complete replacement and are intermediate between the nelsonite and anorthosite specimens just described.

A mass of unusually hard, barren rock, now removed, occurred within the nelsonite body. A microscopic study shows that this rock is andesine anorthosite only slightly modified through replacement by nelsoniteforming materials and associated secondary silicates. That is, it is essentially the same as the material of the disseminated deposits. The composition is approximately quartz, 15 percent; altered pyroxene, 5 percent ilmenite, 5 percent; apatite, 2 percent; and the remainder andesine in grains that average a little les than 1 millimeter in diameter and have been partly replaced by finely disseminated hornblende, clinozoisite, and 
muscovite. Between this horselike mass of feldspar rock and a lean biotite nelsonite is a transition zone about 18 inches wide.

Ilmenite-bearing rocks that contain varying proportions of pyroxenes and biotite, or their alteration products, occur in several places in the region. Some of these have been described as gabbro-nelsonites by Watson and Taber, ${ }^{17}$ but others are so poor in ilmenite and rich in secondary amphiboles that they are best described as amphibolites. These have no commercial value and have been little prospected, and fresh material for study is almost lacking. However, shallow pits and float material show significant relations.

A partly weathered and friable amphibolite nelsonite from the Bryant farm gave fairly satisfactory thin sections that permitted a determination of the minerals and their relations. They all contain small augenlike remnants of anorthosite enclosed in fine-grained mineral aggregates containing pyroxene, amphiboles, biotite, garnet, quartz, apatite, and ilmenite, as shown in plate 13, $A, B, C$. The relations which indicate that these are secondary minerals are described in detail in the section on replacement processes (pp. 19 and 20).

A small nelsonite body cuts the gneiss near the Lynchburg-Roanoke road about 4 miles east of Bedford, and about 30 miles southwest of the Roseland anorthosite area. The mineralized zone is not well exposed but is only a few feet wide. It shows a banded structure, and a zone near the center, perhaps 50 centimeters wide, is composed largely of ilmenite. On each side of this are zones that are strongly schistose in structure and composed of biotite with lessor amounts of ilmenite. This appears to grade into schistose material composed of biotite, ilmenite, and quartz. This, in turn, appears to grade into gneiss, as there seems to be no sharp contact between nelsonite and country rock. A few rods away hard float material occurs whose relations to the material just described cannot be determined. This rock has the following mineral composition: Green hornblende, 50 percent; cummingtonite, 18 percent; ilmenite, 13 percent; apatite, 18 percent; and biotite, 1 percent. Small amounts of quartz and sphene are present. The two amphiboles are described in detail on pages 12 and 13.

\section{RUTHLE NELSONITE}

A small body of rutile nelsonite was mined for its rutile during the summer of 1939 by the American Rutile Co., and has permitted the study of a type of deposit not previously available. This deposit is about a quarter of a mile southwest of Roseland, on the Giles property, mear the junction of Possum Trot Branch and the Tye River.

The rutile nelsonite body is a very irregular lens that is about 25 feet in its longest dimension (east-west), has a maximum thickness of 8 or 10 feet, and has been

${ }^{17}$ Watson, T. L., and Taber, Stephen, op. cit. (Bull. III-A), pp. 138-145. followed to a depth of about 14 feet where it is underlain by anorthosite. The southeast wall is very irregular and gives the ore body its distorted shape.

The ore body is in almost direct contact with altered anorthosite on the north side, but on the south intense shearing has produced a zone of sericite schist 1 foot or more wide. This zone is made up of sericite, finegrained plagioclase, and a few large residual areas of antiperthitic plagioclase. Outside of the zone of intense shearing is a wider zone where narrow shear zones alternate with highly altered anorthosite. The only other minerals observed in the sericite schist are a very little clinozoisite, rutile that has been largely altered to leucoxene and sphene, and a little graphite that is concentrated in thin lenses.

The very close fracturing of the narrow east border of the rutile nelsonite is illustrated in plate $19, A, B$, where the white areas and veinlets represent leucoxene (sphene) that has developed in fractures and shear zones in rutile (black). In the upper part of the snecimen shown in figure $A$ replacement has gone so far that only small individual areas of rutile remain. The nearly horizontal gray zones in figure $B$ and the diagonal zone in figure $A$ represent areas where shearing has been so intense that a schistose structure has been produced. The white area on the right in figure $A$ represents a lens of highly altered anorthosite. Figure $C$ represents a small mass of rutile, with irregular tongुues, and isolated areas of rutile in anorthosite. The gray areas are leucoxene (sphene).

A study of thin sections shows inclusions of muscovite in rutile or apatite, and these probably represent recrystallized sericite or anorthosite. Where anorthosite is in contact with rutile nelsonite there is an abunc'ance of fine-grained sericitic muscovite and a very little chlorite.

The alteration product of rutile is in part typical leucoxene in appearance. but much of it is coersergrained and permits a determination of the indices of refraction, which are those of sphene. Chemical tests show the presence of essential amounts of calcium and confirm the mineral as sphene. Small veinlets of co?rser sphene cut the fine-grained material in a few thin sections. The fine-grained typical leucoxene is also spl one. (See p. 14.)

A body of feldspar 1 foot or more across was encountered within the most massive part of the rutile nelsonite. This body is dark gray and contains abundant sericitic muscovite, but it retains the structure and mineral character of typical antiperthitic plagioclase. The rutile nelsonite in most of the lens is very massive, with grains of rutile and apatite averaging 1 to 2 millimeters in diameter. The richest portion runs 75 to 80 percent of rutile, but in much of the body, especially along the east border, apatite is more abundant. Near the east border and including the closely fractured part of the lens the rutile is coarser-grained and some gaains 
are 1 centimeter in diameter. In this altered part of the vein much ilmenite has formed along fractures in rutile, as illustrated in plate $19, D$. The alteration to leucoxene or sphene illustrated in the same figure evidently occurred after the introduction of ilmenite. In the finer-grained, more massive part of the ore body alteration has been slight, and only small amounts of ilmenite, sphene, and leucoxene have been formed. However, sparse granular ilmenite is disseminated throughout the body, a little pyrite forms disseminated grains, and later pyrite forms films on fracture planes.

\section{MINERALOGY}

The minerals of the Roseland anorthosite and the related dikes, veins, and nelsonite bodies are described in the following sections. The relations of these minerals to one another and their paragenesis are discussed in detail in another section of this report (pp. 15-22). The feldspar of the anorthosite composed of andesine and its enclosed microcline, a little quartz, and the pyroxene of the ferromagnesian facies are believed to be primary pyrogenic minerals. Apatite, rutile, ilmenite, magnetite, biotite, muscovite, amphiboles, clinozoisite, garnet, most of the quartz, chlorite, vermiculite, serpentine, sphene, graphite, pyrite, chalcopyrite, pyrrhotite, and calcite are believed to be secondary.

Antiperthitic andesine.-The primary feldspar of the andesine anorthosite is the blue-gray antiperthitic plagioclase whose occurrence is described on pages 3 and 4. A microscopic study shows that it is composed of andesine, enclosing minute lamellae of microcline, which are very regular in distribution, as shown in plate $3, C$. These lamellae are about 0.003 millimeter thick, 0.03 millimeter wide, and 0.1 to 0.3 millimeter long, and they commonly lie with the greatest length perpendicular to the trace of the albite twinning in sections parallel to (001) and make an angle of $73^{\circ}$ to $75^{\circ}$ with the trace of the (001) cleavage in sections parallel to (010). This orientation corresponds with the plane $(\overline{7} 01)$, which is the commonly observed direction for both perthitic and antiperthitic intergrowths of feldspar. Another set of intergrowths cut the first and were evidently formed later. These later lenses are about 0.027 millimeter wide or almost 10 times as wide as those of the other set. In sections cut parallel to (001) a large proportion of these coarser lamellae are roughly perpendicular to the earlier set and parallel to the albite twinning (010) as shown in plate $3, C$. In some areas this second set of lamellae is very irregular in orientation and distribution, and in a few areas they are entirely absent. This uneven distribution is in contrast with the very even distribution of the earlier fine-grained set.

The even distribution, fine texture, and early formation of the first set of lamellae indicate that they are the result of exsolution in the solid state of an originally homogeneous feldspar, as suggested by Warren. ${ }^{18}$ The later, coarser-textured, and irregularly distributed perthite appears to be the result of partial replacement of the feldspar through deuteric reaction, as described by Andersen. ${ }^{19}$

The following chemical analysis of carefully selected primary feldspar from the mine of the American Rutile Co. at Roseland has been made in the chemical laboratory of the United States Geological Survey.
Analysis of antiperthitic feldspar of Roseland anorthosite
[J. G. Fairchild, analyst]

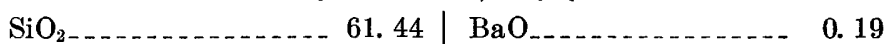

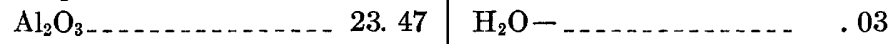
$\mathrm{Fe}_{2} \mathrm{O}_{3}$ (total $\mathrm{Fe}$ ) _..... . $20 \quad \mathrm{H}_{2} \mathrm{O}+\ldots \ldots$
$\mathrm{MgO} \ldots . .05 \quad \mathrm{TiO}_{2 \ldots \ldots} \ldots \ldots \ldots$
$\mathrm{CaO}$
$\mathrm{Na}_{2} \mathrm{O}$
$\mathrm{K}_{2} \mathrm{O} \ldots \ldots \ldots 2$
100. 54

A calculation of the mineral molecules present gives the following proportions:

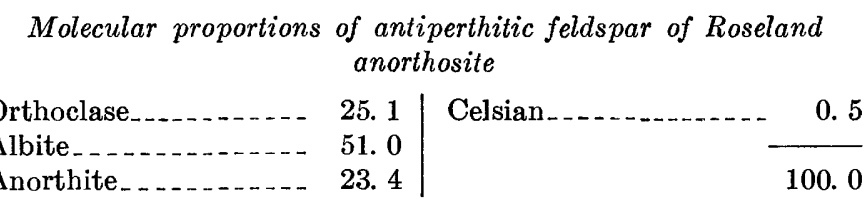

The small aplitic dikes that cut the country rocks in a road cut at the Massies Mill School are composed of perthitic microcline, together with a little rutilated quartz and a few grains of rutile. The very fine, evengrained perthite of the exsolution type is illustrated in plate $3, C$. Surrounding the perthitic microcline are small amounts of perthite-free microcline.

This calculation of the molecular proportions indicates that the plagioclase has a composition of $A b_{68.5}$, a close check on the result based on the indices of refraction, which indicated a composition of $A b_{70}$. The antiperthitic feldspar is illustrated in plate $3, C$.

The granulated feldspar has more variable properties than the feldspar from which it is derived. Most of it has a composition, as indicated by the mdices of refraction, only slightly more sodic than the ungranulated material, and nearly all of it contain" antiperthitic microcline similar to that in the ungranulated material. Minor portions range all the way from andesine to albite, but the abundance of included alteration products makes it difficult to determine closely the composition by optical methods.

The augenlike areas of feldspar at the swimming pool on Tye River 1 mile southeast of Massies Mill (see pl. 10) are composed dominantly of microcline with enclosed perthitic lenses of oligoclase. An unus'ually large proportion of this microcline has been replaced by a very coarse myrmekite, an intergrowth of plagic clase and quartz. This secondary plagioclase, together with the

${ }_{18}$ Warren, C. H., A quantitative study of cortain perthitic feldspars: Am. Acad. Arts and Sci. Proc., vol. 51, No. 3, 1915.

19 Andersen, Olaf, The genesis of some types of feldspar from grarite pegmatites: Norsk geol. tidsskr., Band X, Heft 1-2, 1928. 
primary perthitic oligoclase of the augen, has been much altered to a fine-grained cloudlike material that appears to be a mixture of actinolite and clinozoisite, whereas the microcline has remained nearly fresh.

Microcline.-In its most widespread occurrence microcline is present as antiperthitic lenses in andesine, as described in a preceding section. The augen gneiss contains a large proportion of microcline, and very small amounts occur as interstitial material between andesine grains in the anorthosite. Small pegmatitic lenses that locally cut the anorthosite are composed largely of microcline. The microcline is much less subject to aiteration than the andesine and is commonly fresh in appearance but has been locally replaced by myrmekite.

Rutilated quartz.-A pale grayish-blue quartz is one of the most widely distributed minerals in the Roseland district, where it occurs as irregular masses associated with ferromagnesian lenses and as veins cutting anorthosite. In the earlier workings of the American Rutile Co. masses of such quartz several feet across were encountered. In many places in the district the surface is mantled by fragments of the blue quartz that no doubt were derived from veins. On the Bryant farm such quartz is associated with rutile or with apatite, similar to that shown in plate $12, B$. The blue quartz is coarse-grained but nowhere shows euhedral crystal form, as it seems to have been formed by the replacement of feldspar and not by the filling of cavities.

Great numbers of minute rutile needles with diameters that commonly range from 0.3 to 0.5 micron are enclosed in the quartz. The blue color is caused by the selective reflection of short blue light waves by these rutile crystals, whose diameter is near the optimum for the reflection of the shorter light waves. A large proportion of the rutile needles lie parallel to the basal plane (0001) of the enclosing quartz and make an angle of $60^{\circ}$ with one another, as shown in plate $5, A$, which is reproduced from a photograph of a basal section of the quartz. It seems evident, therefore, that the distribution and orientation of the rutile are controlled by the trigonal symmetry of the quartz.

Clinohypersthene.-A high-iron member of the pyroxene group is one of the essential minerals of the ferromagnesian lenses in the andesine anorthosite and probably also of the oligoclase anorthosite, the nelsonite amphibolites, and the dikes. In the lenses it was originally coarse-grained, and crystals 15 centimeters or more in length are not rare. (See pl. 9.) In the hand specimen it is very dark gray, but in thin section or small grains it is practically colorless, but occasionally shows a faint lavender pleochroism.

The optical properties are as follows: Indices of refraction $\alpha=1.694, \beta=1.710, \gamma=1.715$; birefringence 0.021 ; optical character $(-) ; 2 \mathrm{~V}=62^{\circ}$; dispersion $r>v ; \gamma=\mathrm{b}, \mathrm{Z}$ inclined $44^{\circ}$ to $c$; colorless or with faint lavender pleochroism in thin section. Much of the material closely twinned parallel to (100).

Chemical composition of clinohypersthene [J G. Fairchilı, analyst]

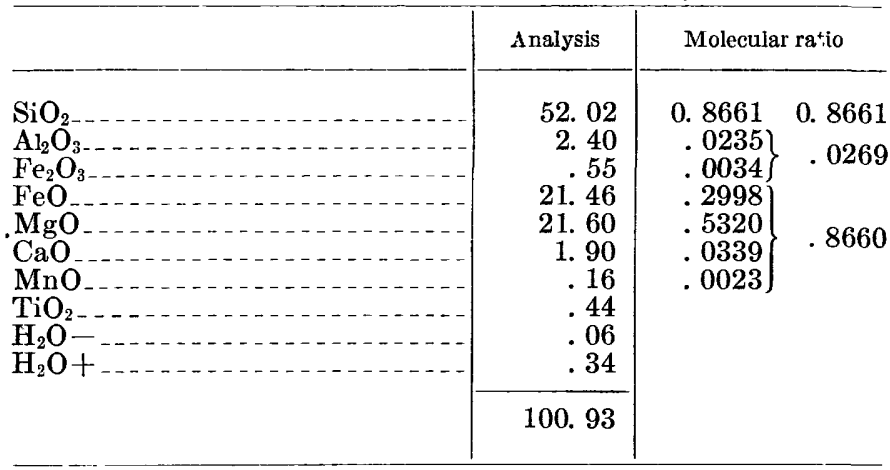

This corresponds with the following mineral composition:

Mineral composition of clinohypersthene

Clinoenstatite $\left(\mathrm{MgO} . \mathrm{SiO}_{2}\right) \ldots \ldots \ldots$. _... $\ldots 2.0$

Clinoferrosilite ${ }^{20}\left(\mathrm{FeO} . \mathrm{SiO}_{2}\right) \ldots \ldots \ldots$. _ _ _. 40.5

Diopside ( $\mathrm{MgO} . \mathrm{CaO} .2 \mathrm{SiO}_{2}$ ) _. _....... 7.5

${ }^{20}$ Bowen, N. L. "Ferrosilite" as a natural mineral; Am. Jour. Sci., 5th ser., vol. 30, pp. 481-494, 1935 .

In the ferromagnesian lenses, this pyroxene is pertly altered to amphiboles. In many specimens only residual areas remain in a groundmass of fibrous actinolite and in the nelsonite amphibolites and ferromagnesian dikes the alteration is almost complete.

Clinozoisite.-The low-iron member of the epidote group, clinozoisite, is one of the most widespread minerals of the Roseland area. It occurs most widely as microscopic grains disseminated in feldspar, where it forms irregular aggregates, tuftlike areas, or rarely elongated prisms that reach a maximum length of 0.2 or 0.3 millimeters. (See pl. 4, A.) More rarely it forms colorless veins not over 1 centimeter wide (see pl. $3, A$ ), which resemble quartz in the hand specimen, and so the mineral is easily recognized only under the microscope. A few small vugs in highly altered feldspar are lined with euhedral crystals that are rarely more than 2 millimeters in length. The high index of refraction and aggregate character cause the dissminated clinozoisite to disperse light and appear gray in thin section. The clinozoisite in small veins occurs as anhedral grains 0.1 to 0.4 millimeter in diameter, which show a brilliant indigo-blue color under crossed nicols.

The indices of refraction are $\alpha=1.700, \beta=1.703$, $\gamma=1.706$, and $2 \mathrm{~V}$ is near $90^{\circ}$. Optical character $(+)$. Colorless and water-clear in small grains. Locally a higher-iron member of the clinozoisite-epidote group of minerals is present. A dull greenish-gray specimen from the mine of the American Rutile Co. has indices of refraction $\alpha=1.722, \gamma=1.746$, which correspond to a low-iron epidote. 
The following analysis represents selected material from one of the veinlets about 1 centimeter wide:

Chemical analysis of clinozoisite

[J. G. Fairchild, analyst]

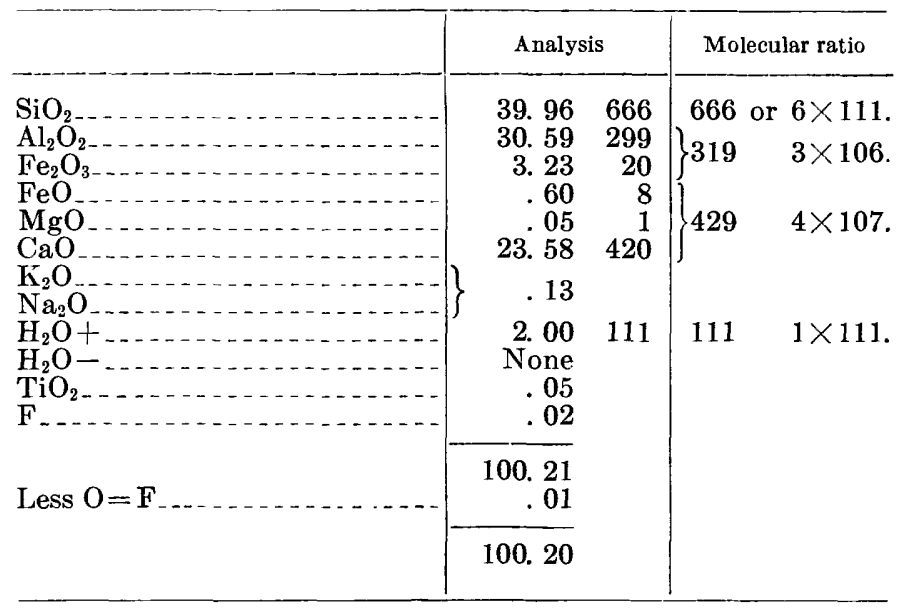

This analysis corresponds very closely with the chemical formula $\mathrm{H}_{2} \mathrm{O} .4 \mathrm{CaO} .3 \mathrm{Al}_{2} \mathrm{O}_{3} \cdot 6 \mathrm{SiO}_{2}$, with only 3.23 percent of $\mathrm{Fe}_{2} \mathrm{O}_{3}$ proxying $\mathrm{Al}_{2} \mathrm{O}_{3}$. Fluorine has not been generally recognized in the epidote group of minerals; in fact, it has not been the custom to look for it, but its presence is not surprising.

Amphiboles.-Various members of the amphibole group are among the most abundant and widespread minerals in the Roseland area. Actinolite or hornblende is an alteration product of pyroxenes in the oligoclase anorthosite and in ferromagnesian lenses and dikes. Along the borders of channels of active mineralization in the anorthosite, in ferromagnesian dikes, and in anorthosite reminants in nelsonites actinolite has replaced feldspar. In parts of the anorthosite farther from channels of active circulation, tremolite or hornblende has formed within feldspar grains, as shown in plate $4, D$.

The hornblende of the ferromagnesian lenses forms veinlike masses which have replaced clinohypersthene as shown in plate 9, and commonly enclose residual areas of it.

The following analysis and indices of refraction of this type of amphibole are given by Watson and Taber. ${ }^{21}$

Analysis of hornblende from Nelson County

[Wm. M. Thornton, Jr., analyst]

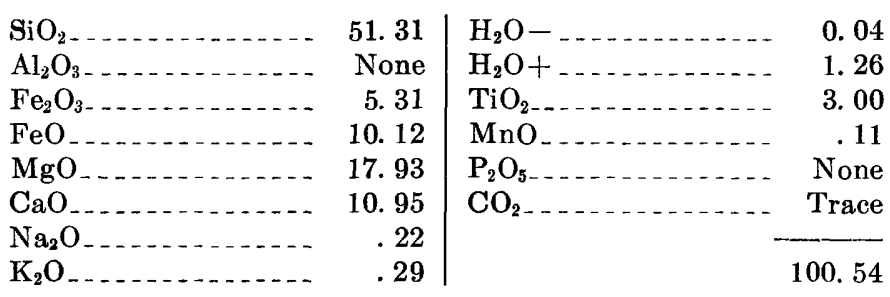

21 Watson, T. L., and Taber, Stephen, op. cit. (Bull. III-A), pp. 219, 220.
The indices of refraction as given by Watson and Taber are $\alpha=1.620, \gamma=1.649$. The indice of refraction as determined by the writer on a specimen of similar material from the mine of the American Rutile Co. are $\alpha=1.618, \gamma=1.642$. These figures indicate that this specimen was very slightly lower in iron than the one studied by Watson and Taber.

The tremolite occurs as minute grains disseminated in feldspar, from which it cannot be separated for accurate study, but the index of refraction is evidently low, indicating a low iron content.

Much of the amphibole secondary to augite in the small intrusive dikes is distinctly green and slightly pleochroic and is evidently hornblende.

One of the most abundant occurrences of amphiboles is found in the nelsonite body of the Southern Mineral Products Corporation, where sheared anorthosite has been replaced by hornblende, as shown in $\mathrm{p}^{\top}$ ates $13, D$, and 15, C. The most intense replacement has occurred along shear zones, but disseminated hornblende has also formed within the augenlike residual areas of anorthosite. There has been a similar replacement of sheared anorthosite in the amphibolite nelsonite from the Bryant farm, as illustrated in plate $13, A, B, C$.

Two amphiboles form abundant minerals in a small ilmenite-bearing lens in replaced schist about 4 miles east of Bedford, Va., described on page 9. A microscopic study revealed a deep-green hornblende and a colorless cummingtonite. These two types formed distinct individuals with sharp boundaries and no zonal relations. A few crystals are composed of green amphibole at one end and colorless cummingtonite at the other, but the change is invariably abrupt. These relations indicated that there was no molecular isomorphism between the two types and it seemed advisable to separate the two and have them analyzed. The results are given in the following table.

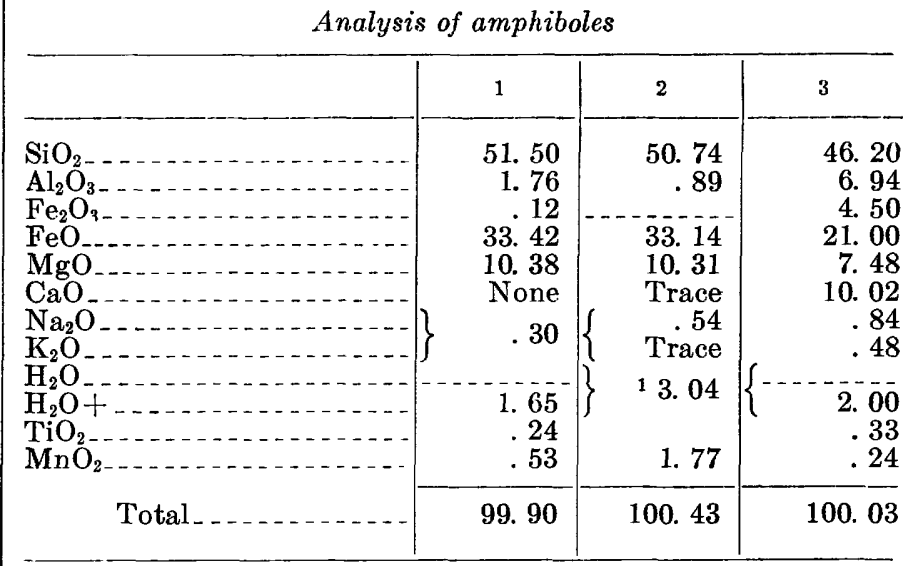

1 Ignition loss.

Analyses 1 and 3 by J. G. Fairchild; analysis 2 by Smith and Brush. Smith, J. L., and Brush, G. J., Reexamination of American minerals: Am. Jour. Sci., 2d ser., vol. 16, p. 48,1853 .

Analysis 1 shows a typical cummingtonite and is surprisingly similar to an analysis of the type ma terial from 
Cummington, Mass., given in column 2. The analysis of the green hornblende given in column 3 shows that it is a high-iron hornblende. The most fundamental chemical difference between the two associated but nonisomorphous amphiboles is the presence of $\mathrm{CaO}$ in the hornblende and its absence in the cummingtonite, but there is also a higher content of $\mathrm{Fe}_{2} \mathrm{O}_{3}$ and $\mathrm{Al}_{2} \mathrm{O}_{3}$ in the hornblende.

The optical properties are as follows:

\begin{tabular}{|c|c|c|}
\hline & Green hornblende & Cummingtonite \\
\hline Indices of refraction.. & $\left\{\begin{array}{l}\alpha=1.661 \\
\beta=1.679\end{array}\right.$ & $\begin{array}{l}\alpha=1.658 \\
\beta=1.670\end{array}$ \\
\hline Birefringenc & $\begin{array}{l}{[r=1.687} \\
0.026\end{array}$ & $\begin{array}{l}\Upsilon=1.688 . \\
0.030\end{array}$ \\
\hline Extinction & $21^{\circ} \ldots$ & $\begin{array}{l}\text { U. Oou. } \\
23^{\circ}\end{array}$ \\
\hline Optical character & $(-)$ & $(+)$ \\
\hline Dispersion & $\begin{array}{l}65^{\circ} \pm 5^{\circ} \\
\mathrm{r}>\mathrm{v} \text { strong }\end{array}$ & $\begin{array}{l}80^{\circ} \pm 5^{\circ} \\
\text { Weak. }\end{array}$ \\
\hline Pleochroism ${ }^{1}$ & $\left\{\begin{array}{c}\text { green. }_{\beta=29^{\prime} \text { GG-Y'i light }} \\
\text { Brice green. } \\
\gamma=37^{\prime} \text { GB-i zinc green }\end{array}\right.$ & None. \\
\hline
\end{tabular}

1 Ridgway color standard.

Micas.-The most widespread mica is a fine-grained sericitic muscovite disseminated in feldspar. A small amount of moderately coarse grained muscovite is associated with biotite in some of the nelsonite bodies, and a little is present in small pegmatitelike masses that locally cut the anorthosite. A pale-brown biotite of sericitic habit has formed around the borders of ferromagnesian minerals or ilmenite, but at a distance of not more than a few millimeters a colorless mica has formed, and this is found in varying proportions throughout the anorthosite. Biotite is associated with ilmenite or rutile in several types of nelsonite. The index of refraction is high as $\alpha=1.665$, which, together with the light color (reddish brown to pale brown), suggests a high titanium but low iron content. The biotite of the nelsonite is later than both ilmenite and apatite, as it fills fractures in both these minerals and locally has replaced apatite. (See pl. 18, $C, D$.)

The brown micas commonly show alteration, and part of them have been changed to chlorite and part to vermiculitelike material. In the upper portion of some of the nelsonite bodies the brown mica has weathered to a claylike material.

Rutile.-The rutile of the Roseland district shows several distinct types of occurrence. The most widespread type forms disseminated grains in the granulated andesine anorthosite. The rutile grains are commonly roughly rounded or irregular in outline but others are angular, rarely show crystal faces, and the diameter commonly ranges from a fraction of 1 millimeter to 10 millimeters. The coarsest type of rutile observed is that left on the surface on the Bryant farm, three-quarters of a mile south of Claypool, where masses as much as 10 centimeters in diameter are made up of individual grains 1.5 centimeters or less across.

The color ranges from a metallic steely black for some of the rutile close to ferromagnesian lenses to mahorany red for that disseminated through the feldspar. In thin section the rutile commonly ranges from lemon yellow to deep brownish orange and shows noticeable pleochroism. A few grains are grayish lavender. Twinning is usually present.

Watson and Taber give chemical analyses of two samples of rutile containing 95.71 and 98.80 percent of $\mathrm{TiO}_{2}, 0.15$ and 0.20 percent of $\mathrm{V}_{2} \mathrm{O}_{3}$, and 0.02 and 0.07 percent of $\mathrm{Cr}_{2} \mathrm{O}_{3}$.

Analyses of two types of rutile are given below.

Analyses of rutile from American Rutile Co. [J. G. Fairchild, analyst]

\begin{tabular}{|c|c|c|}
\hline & Brown & Blank \\
\hline \multirow[t]{2}{*}{ 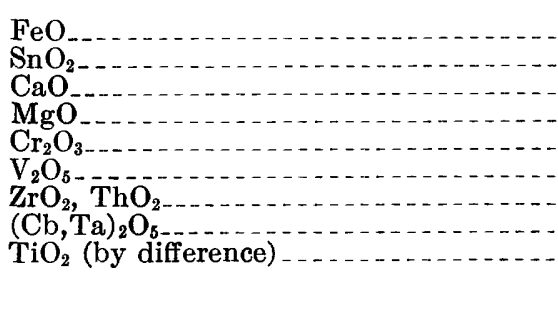 } & $\begin{array}{r}10.40 \\
\text { None } \\
\text { None } \\
\text { None } \\
.04 \\
.28 \\
\text { None } \\
2 \text { None } \\
99.28\end{array}$ & $\begin{array}{r}10.62 \\
\text { None } \\
\text { None } \\
\text { None } \\
.06 \\
.28 \\
\text { Ncne } \\
\text { None } \\
99.04\end{array}$ \\
\hline & 100.00 & 100. 00 \\
\hline Specific gravity & 4. 304 & 4. 280 \\
\hline
\end{tabular}

${ }^{1}$ Iron calculated as FeO.

${ }^{2}$ Less than 0.05 percent, if any.

The foregoing analyses fail to show the cause of the variation in color of the two types of rutile, as a renge in $\mathrm{FeO}$ from 0.40 to 0.62 percent seems insufficient to produce the difference, and other elements are alrost the same in the two samples. It is probable, however, that the dark metallic color is due to the presence of iron in two states of oxidation. The darker type is completely free from microscopic inclusions, and small grains are as transparent as in the paler type.

The rutile in the rutile nelsonite forms rounded, angular, or irregular grains and is similar in appearance to those disseminated in the anorthosite, which renge from about 2 to 10 millimeters in diameter. It is dark brown and is slightly darker than the redcishbrown type of disseminated rutile, but it rarely shows the metallic luster of that occurring close to the feeding channels.

The crystals of rutile enclosed in quartz (see p. 11) are so minute that it is not possible to determine any of the optical properties. Measurements of these crystals show diameters ranging from 0.3 to 0.5 micron and lengths as much as 1 millimeter or more. Thus some of these have a length at least 3,000 times their diameter.

The replacement of rutile by ilmenitie is described on page 18 and pictured in plate 18, $C$. A few specimens show a narrow alteration rim of sphene ("leucoxene," 
see below), although rutile has in general been much less subjected to alteration of this type than ilmenite.

Ilmenite.-The ilmenite occurs in the various types of nelsonite, where it is associated with apatite, biotite, or altered pyroxenes; disseminated in the anorthosite; and in the gneissic border facies. The grains of ilmenite in nelsonite and anorthosite reach 5 or more millimeters in diameter and are irregular or roughly rounded but nowhere euhedral in outline. In the dikes and veins with abundant ferromagnesian silicate minerals, the minute grains of ilmenite form very irregular, wavy, shredlike lenses as illustrated in plate $13, A$. Some grains of ilmenite are slightly fractured and the cracks filled with later biotite and magnetite, but none are crushed to the same extent as the granulated plagioclase. Where associated with magnetite the ilmenite has a brilliant luster and a distinctly purplish color by reflected light, whereas the magnetite has a duller metallic gray color. Ilmenite occurs in cleavage planes of some of the clinohypersthene (see pl. 14, D), where it forms films so thin that they transmit light and show a distinct lavender color. Thus the color shown by transmitted light agrees with that by reflected light. The replacement of rutile by ilmenite is described on page 18 , and much of the rutile shows a narrow alteration rim of sphene.

Sphene (leucoxene).-Throughout the Roseland area, sphene occurs in the form of typical flattened rhombic crystals, and it is especially abundant in the quartz monzonite near its contact with the anorthosite.

The sheared east border of the rutile nelsonite body on the Giles property (illustrated in plate 19) has been very completely a tered to secondary titanium minerals. Some of th \& material, even though very fine grained, may be recognized as sphene by optical methods. Other parts are extremely fine grained and resemble the material called leucoxene.

The presence of sphene is confirmed by the following chemical analysis of a sample made up of the material in question, together with smaller amounts of rutile and ilmenite and a very little apatite.

Analysis of secondary titanium minerals from the Giles property [R. E. Stevens, analyst]

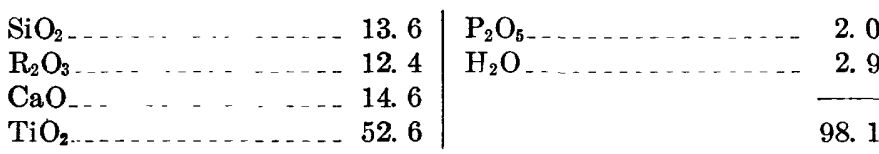

The approximate absence of other silicate minerals indicates that sphene is the source of most of the $\mathrm{SiO}_{2}$, and also of the $\mathrm{CaO}$.

Much of the ilmenite and rutile of the Roseland district is enclosed in thin shell-like films of a secondary alteration product. This is submicroscopically crystalline and has a very high index of refraction, close to that of sphene. An X-ray examination of shell-like films of the material enclosing rutile, shows that the diffraction pattern is that of sphene. The very fine grained material associated with the fine-grained sphene on the Giles property is no doubt the same.

Tyler and Marsden ${ }^{21 a}$ have studied leucoxene by $\mathrm{X}$-ray and found that in most occurrences it was rutile, but in one they found it to be anatase. The "leucoxene" associated with the Magnet Cove rutile is anatase. (See p. 24.) The Roseland "leucoxene" is the first, so far as known, that has been identified as sphene.

Magnetite.-Magnetite is associated with. ilmenite, amphiboles, and biotite in one of the rarer types of nelsonite, where it forms grains of about the same size and shape as the ilmenite. It is dull metallic gray and is much less fresh in appearance than the ilmenite. It also forms small veinlets in minute fractures in ilmenite.

Apatite--One of the most abundant minerals in the Roseland district is apatite, a charactertistic mineral of nelsonite, of which it makes up from 10 to perhaps 35 percent, as illustrated in plates 14 and 15 . It also occurs in lesser amounts in the ferromagnesian dikes and lenses and close to them in the anorthosite and in the border facies. In the nelsonite it forms roughly rounded but not euhedral grains that reach $\varepsilon$, maximum diameter of 2 to 3 millimeters. The grains are colorless and nearly transparent to opaque white where the mineral is fresh. Apatite also occurs in irregular masses in blue quartz on the Bryant farm. (See pl. $12, B$.)

Watson and Taber ${ }^{22}$ give the following analysis of an almost pure fluorapatite from the mine of the General Electric Co.:

Analysis of apatile

[Wm. M. Thornton, Jr., analyst]

\begin{tabular}{|c|c|c|c|}
\hline $\mathrm{CaO}_{\ldots} \ldots \ldots$ & 54. 37 & $\mathrm{Fe}_{2} \mathrm{O}_{3} \ldots$ & 0.61 \\
\hline $\mathrm{MgO}_{\ldots} \ldots \ldots$ & .53 & $\mathrm{H}_{2} \mathrm{O} \ldots \ldots$ & .19 \\
\hline $\begin{array}{l}\mathrm{P}_{2} \mathrm{O}_{5} \\
\mathrm{~F}\end{array}$ & $\begin{array}{r}41.30 \\
2.50\end{array}$ & & 100.13 \\
\hline $\mathrm{Cl}$ & .10 & $\mathrm{O}=\mathrm{F} \ldots$ & 1. 07 \\
\hline $\begin{array}{l}\mathrm{SiO}_{2} \\
\mathrm{TiO}_{5}\end{array}$ & $\begin{array}{l}.33 \\
.20\end{array}$ & & \\
\hline
\end{tabular}

The indices of refraction are $\epsilon=1.630, \omega=1.634$.

Minor minerals.-A minor mineral of th 9 rocks of the Roseland district is graphite. It is probably most abundant at the old mine of the General E'actric Co., where it occurs in ferromagnesian lerses called "gabbro" ${ }^{23}$ and to a lesser extent in the anorthosite as flakelike grains disseminated in highly altered feldspar.

On the old dumps of the mine are numerou masses of a highly altered porous rock composed of andesine, quartz, pyrite, clinozoisite, and sericite together with several percent of graphite that occurs in flakes 1 or

21. Tyler, S. A., and Marsden, R. W.,The nature of leucoxene: Jour. Sed. Petrology, vol. 8, po. 55-58, 1938.

${ }_{22}$ Watson, T. L., and Taber, Stephen, op. cit. (Bull. III-A), p. 223. ${ }^{23}$ Idem, p. 229. 
rarely 2 millimeters in diameter. Grains of granular quartz are commonly surrounded by films of graphite, and the embayment of clinozoisite and the formation of films of graphite in cleavage planes.in muscovite indicate that graphite is later than both these minerals. Graphite and pyrite are commonly associated and appear to have formed at about the same time.

Small plates of graphite as much as 2 millimeters across, occurring sparsely in blue quartz, are present in the mine of the American Rutile Co., and very small amounts occur in sericite schist bordering the rutile nelsonite on the Giles property.

Pyrite, althouth not an abundant mineral, is present in varying amounts in nearly all types of rock in the region. It is associated with graphite in the old mine of the General Electric Co., as described above. It occurs as a minor mineral associated with pyrrhotite and rarely with chalcopyrite in the ferromagnesian lenses (see pl. 9, B), where pyroxenes have been altered to hornblende. A very fine grained dendritic type of pyrite or marcasite forms gray aggregates (see pl. $4, B$ ) in some of the altered anorthosite in the feldspar prospect on the Piney River 1 mile west of the main road between Charlottesville and Lynchburg. Pyrite is also present in many of the nelsonite bodies as small rounded grains that average about 1 millimeter in diameter, and a specimen of nelsonite from the dump of the General Electric Co.'s mine carried about 1 percent of pyrite.

Pyrrhotite is somewhat less abundant than pyrite but is widespread and especially abundant in some of the lenses of amphiboles that have replaced clinohypersthene. A specimen with about equal proportions of amphiboles and partly replaced clinohypersthene contains several percent of pyrrhotite in irregular areas that reach a maximum diameter of 15 millimeters. Associated with this are small amounts of pyrite and chalcopyrite.

Where ilmenite and sulfides occur together there appears to have been no replacement of one by the other, and so the mutual spatial relations do not show the relative age.

Sphalerite occurs in a small vein on Allen Creek half a mile southeast of Rose Union, where it is associated with quartz, pyrite, and a very little galena. This vein may be related to the sulfides previously described, but the scant specimens available from the old dump give no evidence about the mineralization processes or the relation to the anorthosite and associated rocks.

Calcite is nowhere abundant but is widely distributed in the anorthosite and associated rocks. It forms rare scattered grains in the anorthosite and numerous small veins or lenses in the border facies. Near Rose Mills, small veins and nests of calcite are especially abundant, and irregular masses form an essential part of the anorthosite lenses, which cut the country rock near the point where the Charlottesville-Lynchburg road crosses the Tye River. Disseminated grains of calnite are commonly present in altered gneissic quartz monzonite near the contact with the anorthosite.

A sooty black cobalt-bearing clay forms small seams filling joint cracks in the nelsonite body being mined by the Southern Mineral Products Corporation. A chemical analysis of this material by R. C. Well is given below.

\begin{tabular}{|c|c|c|c|}
\hline \multirow{2}{*}{\multicolumn{4}{|c|}{$\begin{array}{r}\text { Analysis of cobalt-bearing clay from South } \\
\text { Corporation's mine } \\
\text { [R. c. Wells, analyst] }\end{array}$}} \\
\hline & & & \\
\hline $\mathrm{SiO}_{2 \ldots} \ldots \ldots \ldots$ & 29. 41 & $\mathrm{TiO}_{2} \ldots$ & 0.76 \\
\hline $\mathrm{Al}_{2} \mathrm{O}_{3} \ldots \ldots$ & 28.97 & $\mathrm{CO}_{2} \ldots \ldots$ & None \\
\hline $\mathrm{Fe}_{2} \mathrm{O}_{3 \ldots} \ldots$ & 12. 20 & $\mathrm{NiO} \ldots \ldots \ldots \ldots$ & .03 \\
\hline $\mathrm{MgO}_{-}$ & .18 & $\mathrm{CoO}$ & 1. 51 \\
\hline $\mathrm{CaO}$ & .60 & $\mathrm{MnO}+\mathrm{O}$ & 8. 28 \\
\hline $\mathrm{Na}_{2} \mathrm{O}_{-}$ & .18 & $\mathrm{Li}_{2} \mathrm{O}_{\ldots}$ & None \\
\hline $\mathrm{K}_{2} \mathrm{O}_{\ldots} \ldots$ & .26 & $\mathrm{CuO}$ & None \\
\hline $\mathrm{H}_{2} \mathrm{O}-\ldots$ & 4. 65 & & \\
\hline $\mathrm{H}_{2} \mathrm{O}+\ldots \ldots$ & 13. 13 & & 100. 16 \\
\hline
\end{tabular}

This analysis shows that the material is essentially a kaolinitic clay with admixed oxides of iron, marganese, and cobalt. The source of the manganese and cobalt is not evident, as manganese- and cobalt-bearing minerals have not been recognized in the anorthosite and associated minerals.

\section{ORIGIN OF THE ROCKS AND. MINERALS}

The preceding sections of this paper describe the general geology and the rocks and minerals of the Rcseland district and provide a basis for a consideratior of their paragenesis. This involves a correlation of the field geology with petrology, mineralogy, chemistry, and physics. It includes the origin of the anorthosite by differentiation, its mode of emplacement, and its physical condition during and after emplacement. It considers the relations between the anorthosite, the intrusive dikes, the nelsonite bodies, and the secondary minerals. It involves the physical and chemical character of the solutions that invaded these rocks and deposited secondary minerals and endeavors to explain the factors controlling mineral formation. This le ${ }^{\text {a }}$ ds to a consideration of the method by which these solutions were segregated from their parent rock and the manner in which they were transferred to the zone of mineral deposition.

The origin of the rocks is not taken up in the puroly descriptive section on petrography; the secondary minerals are described there, but their significance is not discussed in detail. The character and mutual relations of minerals, more especially the secondary miner $\mathrm{ls}$, present evidence about the more theoretical problems of paragenesis. For that reason description and interpretation are intimately interwoven in the sections on origin. First the rocks of pyrogenic origin are considered. 
These rocks were invaded and more or less modified by groups of secondary minerals, whose origin is discussed under "Physicochemical processes."

\section{ANDESINE ANORTHOSITE}

The character of the Roseland anorthosite, its feldspathic composition with andesine enclosing antiperthitic microcline, and its crushing and granulation throughout the area are described in preceding sections. This essentially monomineralic character suggests that the genetic history of this rock may be similar to that of the anorthosites of the Adirondack region.

Anorthosites have been intensively investigated within the last few years, and several geologists have published papers on their mode of origin and emplacement. Bowen ${ }^{24}$ has advocated a formation by crystal accumulation followed by intrusion of the mushlike crystal mass, after which the interstitial liquid material was largely squeezed out by filter-press action. He says: ${ }^{25}$ "But of no such rock can it be said that a protoclastic structure is an almost universal character, as it can of an anorthosite. The structure is evidence of the fact that when an anorthosite mass moves it does so only with accompanying granulation." Bowen ${ }^{2 e}$ also stresses the improbability of a differentiation process that would produce magmas having a purely feldspathic composition.

Balk, ${ }^{27}$ after a field study of the Adirondack anorthosites, concludes:

A large mass of poorly differentiated parental magma with appreciable quantities of suspended solid crystals of labradorite and fewer ferromagnesian minerals has advanced in a general southwesterly direction, obliquely upward.

During the very long history of intrusion this parental magma has differentiated into three rocks-gabbro, anorthosite, and syenite. Gabbro and anorthosite are regarded as crystal differentiates, produced by the mechanical accumulation of solid mineral grains. Syenite plays the role of the mother liquor from which the other rocks differentiated. ***

Driven forward by the constant magma current from northeast to southwest, the individual labradorite clusters have been compacted in the southwestern, distant corner of the magma chamber. The crystals have rubbed and sheared against each other under enormous compression, until the available interstices were tightly cemented by powder of crushed labradcrite fragments. In proportion as the compression increased, the mother liquor has been ejected.

Buddington, ${ }^{28}$ after a restudy of the anorthosites of the Adirondack area, makes the following statements:

All the phenomena are consistent in indicating formation of the anorthosite through differentiation from a gabbroic anorthosite magma with a distinct content of volatiles. The hypothesis

${ }_{24}$ Bowen, N. L., The problem of the anorthosites: Jour. Geology, vol. 25, pp. 209243, 1917; The evolution of igneous rocks, pp. 170-174, 1928.

${ }^{25}$ Bowen, N. L., op. cit. (1928), p. 172.

${ }^{26}$ Idem, p. 170.

${ }_{97}$ Balk, Robert, Structural study of the Adirondack anorthosite: Min. pet. Mitt., Band 41, Heft 3-6, pp. 411-412, 1931.

${ }^{28}$ Buddington, A. F., Origin of anorthosite in the Adirondacks and in general: Am. Geophys. Union Trans. 17 th Ann. Meeting, Washington, pt. 1, pp. 255, 256, 1936. of a rest-magma of the composition of the quartz syenite on the one hand, squeezed out from an anorthositic fraction on the other, does not satisfy the requirements of the data. $* * *$

Analogy with stratiform sheets suggests the possibility that the anorthosite horizon consisting of bytownite and perhaps calcic labradorite may well be present above the paridotite shell in the interior of the earth. Partial melting of such an anorthosite shell or stratum would yield a gabbroic anorthosite magma of the requisite character for the Adirondack typ? of intrusion and would be consistent with the generally restricted composition of the plagioclase shown by such bodies. The restriction of anorthosite of this origin to the pre-Cambrian would find a natural explanation in higher temperatures locally or as a whole, at higher levels in the earth's crust at this period.

The mode of formation of rocks made up of one or almost exclusively one mineral has always presented an interesting problem in geology and is one of the reasons for an especial interest in anorthosites. Investigations of this problem have centered around the anorthosites of the Adirondack region. Here parts of the anorthosite bodies are composed essentially of plagioclase, but they commonly contain small proportions of dark minerals and grade over into almost typical gabbros. The plagioclase ranges from labradorite to andesine, with andesine the typical mineral in much of the rock. ${ }^{29}$ Thus the Roseland anorthosite is no more sodic than many of the anorthosites of the Adirondack region, but on the other hand it is more completely free from dark minerals than almost any part of those rocks.

Anorthosites are commonly believed to be the result of differentiation from a magma of more normal composition. Some process has brought $\varepsilon$,bout a segregation of plagioclase, or of a magma that crystallized into plagioclase and a little microcline from an earlier magma, that perhaps originally had a gabbroic composition. The theory of crystal settling and intrusion of a mush of feldspar crystals has been outlined and seems to accord with the relationships presented in the Roseland district. However, the work of Buddington casts doubt on this explanation for the Adirondack region, and so to extend it with certainty to the Roseland district is premature.

The exposures in the Roseland district are so sparse that it is not possible to map the significant rock structure, as Balk has done in the Adirondacks, and arrive at definite conclusions about the direction of movement of the intruding mass. No rock corresponding to the syenite that Balk believes to have been an interstitial magma squeezed out from the anorthosite is present in the Roseland district. Tl a injection gneisses along the border and small pegmatitic and aplitic zones in the anorthosite may perhaps correspond to such material, but these local occurrences are not representative of large-scale expulsion of residual magma. If such material escaped from the anorthosite, most of it must have been deposited at higher levels, now largely removed by erosion.

${ }^{20}$ Idem, pp. 255,256 


\section{OLIGOCLASE ANORTHOSITE}

The gray granular anorthosite has undergone alteration of the same type as the nearly white andesine anorthosite. It is now composed of antiperthitic oligoclase of about the composition $A b_{80}$, pyroxene partly altered to fibrous amphibole, ilmenite, rutilated quartz grains that are commonly distributed in zones, and disseminated micas, amphiboles, and clinozoisite.

No large residual feldspar masses are present, as in the andesine anorthosite, but the marked distortion of crystals and the identity of the antiperthitic structure, with that in the granulated andesine anorthosite indicate that it has undergone similar granulation, although it was probably originally a medium-grained rock. The quartz, pyroxene, and ilmenite are in part disseminated through the rock, but large proportions of them occur together in lenses and zones that extend for several centimeters and produce a schistose structure. The quartz shows strain shadows but is ungranulated, and ilmenite shows only minor cataclastic effects. This suggests that the secondary minerals in the lenslike areas have not undergone granulation by dynamic forces but were introduced into shear zones by solutions after granulation of the oligoclase anorthosite, just as they were in the andesine anorthosite.

In general the same types of disseminated minerals are present in the oligoclase anorthosite as in the andesine facies. However, ilmenite is the characteristic titanium mineral rather than rutile. The dominant secondary silicate of the oligoclase anorthosite is pale-green actinolite, which has formed abundantly throughout the feldspar and also as an alteration product of augite. In some areas pyroxene has been completely altered, but in others residual masses are present. Biotite has formed rather than sericitic muscovite, as in the andesine anorthosite. Part of the quartz may be primary, but much of it occurs in small lenses associated with apatite, ilmenite, and actinolite-rich areas, where it appears to be secondary.

The oligoclase anorthosite has about the same megascopic texture as the gneissic quartz monzonite, and the physical relations suggest that it may be a block, or a roof pendant of the quartz monzonite enclosed in the andesine anorthosite and partly replaced by it, but microscopic studies indicate that it is a facies of the anorthosite. If it is altered quartz monzonite, the replacement has been so complete that all primary biotite and individual grains of potassium feldspar have been destroyed, and only minerals and mineral relations characteristic of the anorthosite are now present.

Near the point where the Roseland road leaves the Charlottesville-Lynchburg road and about half a mile southeast of the anorthosite body is a quarry where the effects of contact metamorphism of the quartz monzonite may be observed. Here the plagioclase has been highly altered to clinozoisite and sericite, and much titanium in the form of sphene has been introduced, but the microcline, as in the anorthosite itself, has been little altered. Microcline appears to be the mineral most resistant to alteration in both the quartz monzonite and the anorthosite, and therefore microcline should be expected to persist, to some extent at least, in any masses of gneissic quartz monzonite that had become enclosed in and altered by anorthosite. On the other hand, the gray granular rock (oligoclsse anorthosite) encountered in the tunnels shows no individual crystals of microcline, but only the antiperthite that is characteristic of the anorthosite. It therefore seems probable that the gray granular rook represents simply a facies of the andesine anorthosite. Masses of one facies of an anorthosite mass enclosed in another seem to characterize many anorthosites. (See pp. 23-26.)

\section{QUARTZ LENSES}

Some quartz forms definite veins at a distance frcm centers of intensive mineralization, but most of it occurs in or near such areas, and much of it appears to have been introduced into the feldspar together with the clinohypersthene lenses. Similar quartz is also abundant as disseminated lenses in the gray granular facias of the anorthosite described above, and in the injection gneiss that forms a border facies at Rose Mill. (See pl. 16, B.)

Although quartz is in general more subject to $\mathrm{d}^{+-}$ namic granulation than feldspars, the large masses of blue quartz show almost no granulation, though strams are commonly present. This indicates that the blue rutilated quartz belongs to a stage of mineralization later than the granulation of the anorthosite. This is more conclusively shown by the veins of quartz cutting the anorthosite and by the veinlets of quartz cutting feldspar crystals that may be observed in most of the thin sections examined. The blue quartz contains abundant rutile needles, and so it is evident that some titanium was being introduced at the same time that this type of quartz was introduced, although it is not clear that thrs time corresponds with the period of the greatest introduction of rutile and ilmenite.

\section{BORDER FACIES}

The border facies as developed at Rose Mills is a typical injection gneiss. The lenses of anorthosite material have been introduced along the schist planes of the invaded rock. This rock was for the most part a biotiterich quartz schist, but some lenses of altered quartz monzonite seem to be present. The sequence of events at the Rose Mills locality seems to have been as follows: The deposition of a quartz-rich sedimentary materisl; its metamorphism, with the development of marked schistosity; the intrusion of lenses of quartz monzonite; the introduction of lenses of anorthosite material along schist planes; the introduction of lenses of 
pyroxenes along shear planes (see pl. 16, $B$ ); and the introduction of secondary minerals including blue quartz, apatite, rutile, ilmenite, amphiboles, biotite, and clinozoisite. The physical character of the anorthosite material during its introduction is not clear, but it was probably a water-rich magma, perhaps of pegmatitic or aplitic character. This is indicated by the impregnation by feldspathic material of the schist associated with the anorthosite lenses. Subsequent mineralization was similar to that in the process affecting the entire anorthosite mass.

\section{FERROMAGNESIAN DIKES}

Numerous dikes occur in the Roseland district and are well represented in the mine of the American Rutile Co. at Roseland and near Rose Mills. These dikes cannot all be definitely assigned to a single period of intrusion; although this seems probable, as all show similar alteration.

The dikes are sharp-walled, yet they were intruded before the introduction of the solution that altered both anorthosite and dikes. These solutions were able to penetrate throughout the anorthosite, producing marked mineralization, even at a distance from channels of introduction. These relations show that the dikes were intruded after the anorthosite became rigid enough to fracture, but they suggest a porosity in the enclosing anorthosite, due to incomplete consolidation, probably incomplete cooling, and introduction of the dikes soon after the anorthosite was formed.

The ferromagnesian dikes exposed in the region are clearly not an adequate source for the solutions whose replacement products indicate a ferromagnesian source. This indicates the presence in depth of a ferromagnesian rock and suggests its relationship with the hypabyssal dikes-that is, the anorthosite, the dikes, the parent abyssal rock of which they are the offshoots, and the escaping solutions are all believed to be genetically related and to have been intruded without any great time intervals. This accords with the widely accepted view that anorthosites and the commonly associated ferromagnesian rocks are differentiates from the same parent magma, although not all are agreed as to the mechanism of that differentiation.

\section{DISSEMINATED MINERALS}

The rutile produced in the Roseland district is recovered from disseminated deposits in granulated anorthosite, in which it occurs in association with ilmenite and a varied group of other secondary minerals. The disseminated ilmenite is most abundant in the lenses of ferromagnesian minerals, close to them or to fracture planes that cut the anorthosite. It is also abundant in the injection gneisses, along the borders of the andesine anorthosite, in the gray oligoclase anorthosite, and in the ilmenite nelsonite discussed on pages
20-22. Ilmenite commonly forms very irregular grains or lenslike areas, which reach a maximum length of about 1 centimeter, as shown in plates 13,14 , and 15 . Rutile is also associated, although less closely, with the zones of fracture. Small amounts are present in the ferromagnesian lenses and close to them, where ilmenite is the dominant titanium mineral; but rutile becomes dominant only at some distance from such zones. Thus ilmenite and rutile show zonal relations to each other.

The proportions of disseminated rutile in the mines of the American Rutile Co. are extremely variable but average only a few percent. The mode of occurrence of the rutile is illustrated in plates 1 and 11, where it shows as nearly equidimensional grains that have the same general form as the ilmenite and that range from a small fraction of a millimeter to 10 millimeters in diameter. The microscopic needles of rutile enclosed in quartz are described on page 11 and illustrated in plate 5, $A$. In the mine of the American Rutile Co. granular rutile of visible size is commonly absent in the blue quartz, but on the Bryant farm numerous masses of float quartz contain rutile in scattered grains that reach several millimeters in diameter. In the same area other masses of blue quartz contain disseminated grains and aggregates of apatite. (See pl. 12, B.)

Most of the ilmenite, rutile, and associrted apatite grains are unfractured, and in the few crrstals where slight fracturing has occurred displacement of the fragments is at most slight. Many specimens in the transition zone between ilmenite and rutile show that rutile has been replaced by ilmenite, as illustrated in plates $18, A, B$, and $19, D$. In some specimens narrow, irregular ilmenite borders surround rutile crystals, other grains of rutile are cut by numerc is fractures along which ilmenite has formed, and some contain several small isolated residual areas of rutile enclosed in ilmenite. Ilmenite is commonly surrounded by a narrow zone of the alteration product laucoxene as shown in plate $18, B, C$, and less commonly leucoxene has formed around rutile. Sphene seems to have formed at about the same time as the leucoxene but largely by direct replacement of feldspar, although some appears to be an alteration product of rutile.

Apatite is typical of the various types of nelsonite but also occurs locally in ores of the disseminated type and the border facies, where it commonly forms crystal aggregates, rather than isolated grains. The mode of occurrence of small lenses of nelsonite in feldspar in the mine of the American Rutile Co. is discussed on page 21 and pictured in plate $12, A$. Apatite aJ o occurs in some of the ferromagnesian lenses, where it forms irregular masses that cut through or send projections far into single crystals of hypersthene. (

Beginning with the formation of titanium minerals, but probably continuing after them, a group of secondary silicates was deposited. Like the titanium min- 
erals, they show a zonal relation to shear zones, and all are the result of the replacement of feldspar. The thoroughly granulated portions of the anorthosite, which commonly show evidence of intense replacement, contain microscopic disseminated grains of micas, actinolite, tremolite, clinozoisite, and more locally titanium minerals. These grains may be rather uniformly scattered through feldspar, form irregular swarmlike areas, or occur in zones along minor fractures. (See pls. 2, 3, and 4.) The feldspar matrix around them is fresh and unaltered. The secondary minerals commonly form mixed aggregates, but one or more of them may predominate over the others. Biotite occurs only near ferromagnesian lenses or ilmenite and is associated with actinolite. Thus ilmenite, biotite, and actinolite (minerals carrying essential iron) are localized near feeding fractures but are commonly associated with low-iron sericite and clinozoisite. Sericitic muscovite, tremolite, and clinozoisite commonly occur together at greater distances from feeding fractures, and sericitic muscovite and clinozoisite are present throughout the mass. Some of the feldspar contains small numbers of minute rutile grains somewhat similar to those in the rutilated quartz. It is not clear when these formed, but localized occurrence and absence from ungranulated feldspar suggest that they are a product of replacement.

\section{FERROMAGNESIAN LENSES}

Numerous roughly parallel lens-shaped masses of ferromagnesian rock occur in parts of the quarry of the American Rutile Co.'s mine. These are very irregular in form and range from mere stringers 1 millimeter or less in width to lenses that are rarely more than 10 or 15 centimeters wide. Some are sharp-walled, but others grade out into areas of disseminated minerals in anorthosite. The relation of the ferromagnesian lenses to fracture zones is shown in plates 6,7 , and 8 , although nearly all specimens show the same relation more or less clearly. The major fractures along which replacement has been most intense are roughly parallel and are occupied by coarse-grained clinohypersthene that has been partly altered to a fibrous aggregate of amphiboles. (See pls. 6 and 9.) Another set of small, roughly parallel fractures makes an angle of about $45^{\circ}$ with the major ones. The portions of these closest to the larger lenses tend to widen and are filled with pyroxenes and their alteration products, but the narrower portions are filled with biotite, as shown in plates 6 and 7 .

A pyroxene, probably clinohypersthene, also formed lenses and irregular masses in the border facies of the anorthosite at Rose Mills, as illustrated in plate $16, B$. This material, however, has been completely altered to a compact fibrous aggregate of hornblende crystals. Hornblendes, probably derived from orthorhombic pyroxene, forms masses up to several feet in diameter in partly kaolinized feldspar, on the Bryant farm on Allen Creek, near the south border of the anorthosite body.

There are two possible theories of formation of the lenses: they may be considered primary products of differentiation, or secondary products resulting from replacement. The anorthosite mass is believed to have been formed by segregation of crystal fractions, with the lighter feldspar tending to float and the ferromagnesian minerals to sink. Aggregates of these sinking crystals may have been caught in parts of the largely crystalline anorthosite and introduced together with it during intrusion. This would tend to drag the ferromagnesian aggregates out into lenslike groups. That is, the pyroxene lenses may be assumed to be products of segregation. The shearing along these lenses me.y be explained as being later than the formation of the pyroxene and connected with the introduction of solutions that altered the pyroxenes to hornblende.

This segregation origin of the pyroxene lenses is believed to be improbable for the following reasons. Their distribution seems to be in general controlled by shear zones that have the same direction in the part of the quarry where the lenses occur and in the more extensive parts where they are absent. However, mineralization has occurred along all the shear zones of the quarry and seems to have differed only in being more intense or in representing a little earlier stage in the clinshypersthene lenses. Thus the direction of shear was probably not controlled by the direction of pre-existing clinohypersthene lenses but preceded their introduction. Some of the lenses are near but not directly in shear zones, and many have the irregular form that commonly characterizes replacement. The large masses of c'inohypersthene show little or no granulation. Small fingerlike offshoots of clinohypersthene were formed in the échelon fractures that make an angle of about $45^{\circ}$ with the major ones. Very irregular or badly corroded sreas of feldspar along the border or within the clinohypersthene masses are partly replaced remnants of anorthosite. The large irregular masses of hornblende on the Bryant farm are made up of coarse crystals that fonetrate the feldspar in all directions, giving shapes that would not have survived, had they been present during intrusion. These relations seem to accord with the theory of replacement by clinohypersthene better than with that of primary products of crystallization.

Three distinct stages were represented in the formation of the clinohypersthene-lens facies of anorthosite. The first was the formation of the purely feldspathic anorthosite, the second the introduction of clinohypersthene by replacement of the anorthosite, and the third the formation of all the other secondary minerals, including quartz, apatite, ilmenite, rutile, amphiboles, sulfides, and micas. There are evidences of a mineral sequence 
within the third group, but they are believed to be closely related genetically, and there was no doubt much overlapping in their time of formation.

The mutual relations of the various minerals of the ferromagnesian lenses that cut the anorthosite are as follows: The clinohypersthene shows various degrees of alteration. In some specimens secondary amphiboles have formed only narrow films along the borders of crystals, or along small crosscutting veins, as shown in plates 6 and $9, B$. Commonly alteration has occurred along the cleavage planes in clinohypersthene, so that the rock is now composed of alternating lenses of that mineral and amphiboles (see pl. 9, $A$ ), but in other parts alteration to a fibrous aggregate of amphiboles has been almost complete. Ilmenite is associated only with minerals that have invaded the clinohypersthene crystals and nowhere occurs in unaltered portions. (See pls. 14, $D$, and 17, $A, B, C$.) Most commonly ilmenite and amphiboles occur together in these veins, but, as shown in plate 17, quartz and ilmenite have formed together in cleavage planes in clinohypersthene. On the other hand, plates $5, B$, and 8 show that amphiboles have replaced quartz, and this seems to be the most general relation. Sulfides occur together with amphiboles in veins cutting clinohypersthene. (See pl. 9, B.) Micas did not form directly within the clinohypersthene masses but along their borders and in the small echelon fractures associated with the major ones. Biotite was formed abundantly in the injected schist at Rose Mills. Biotite has been partly altered to chlorite.

The relations just described indicate that the andesine of the anorthosite preceded all other minerals and was followed by clinohypersthene, which in turn was followed by all the other minerals except a small part of the quartz. Most of the quartz preceded apatite, ilmenite, and amphiboles. Biotite and clinozoisite were probably formed at about the same time as amphiboles. An exception to this order is that part of the ilmenite and amphiboles and part of the ilmenite and quartz were formed together.

\section{NELSONITE}

Some of the nelsonite bodies in the Roseland district are so poorly exposed that it is not possible to make detailed studies of the mineral relations and to reach definite conclusions about their mode of origin. Others of the "hard ore" type are composed almost wholly of apatite and ilmenite and do not show many significant relations. However, many of the nelsonite bodies, or parts of bodies with a more varied mineral content, show relations that seem to indicate very clearly the mode of origin.

Replacement processes seem to have been the controlling factor in the formation of nelsonite. Even the nearly pure apatite-ilmenite nelsonite shows evidence of a sequence of minerals, as the apatite is rounded and embayed, and ilmenite veinlets commonly cut apatite grains, as shown in plates $14, A, 17, D$, and 18, $C, D$. Biotite is present in varying amounts in nearly all types of nelsonite, and in all of these its fresence as veins cutting apatite, ilmenite, or rutile (see $\mathrm{p}^{\mathbf{1}} .18, C, D$ ) is evidence of its secondary origin. The replacement of rutile by ilmenite shows that at least fart of the ilmenite is secondary. Veinlets of magnetite in ilmenite show the late introduction of at least part cf the iron.

The minute veinlets of quartz and ilmenite in clinohypersthene, illustrated in plate 17, afford excellent evidence of the secondary character of the ilmenite, as they follow cleavage planes in clinohypersthene and hence are later than that mineral. The invasion of clinohypersthene by ilmenite is shown in plate $14, D$. A similar relation is shown by veinlets of l ornblende and ilmenite in the cleavage planes in clinohypersthene.

The most informative of the nelsonite bodies of complex mineralogy and abundant silicate minerals is that being mined by the Southern Mineral Products Corporation on the Tye River. Near the footwall of this body are numerous small lenses of anorthosite, and many small lenses of nelsonite cut the enorthosite country rock beyond the main body of nelsonite. The nelsonite shows a marked schistosity that is parallel to the shear zones in the anorthosite along which these small lenses of anorthosite have been formed, as illustrated in plates 13 and 15 . The lenses in the anorthosite are typical andesine anorthosite and show various degrees of replacement. One large body, now removed, contained a few percent of apatite and ilmenite but was not essentially different from the anorthosite of the disseminated deposits. It contained the usual secondary minerals, including tremolite, sericite, and clinozoisite disseminated in antiperthitic andesine. On its border this mass graded over into liotite-rich nelsonite.

A small lens of anorthosite from the central part of the anorthosite is composed of nonperthitic andesine that has been partly replaced by actinolite, sericite, and clinozoisite, with a few completely altered augen similar to those discussed in the next paragraph.

The fresh hornblende nelsonite illustrated in plate $13, D$, is composed of small augen surroundel by hornblende in parallel wisps. A few of these augen are andesine which has remained unreplaced or only partly replaced, but most of them are fine-grained aggregates composed of secondary albite, hornblende, and clinozoisite. The only difference between the two specimens just described is that the nelsonite was very closely sheared, permitting the easy access of solutions and very thorough replacement, while the anorthosite lens escaped this close shearing. Other lenses nearer the contact are intermediate between these two in the degree of replacement.

Material of another type that shows the relation between nelsonite and anorthosite was obtsined from the dumps of the old General Electric Co.'s mine and 
is shown in plate 11. The lighter-colored portions near the bottom and the right side and isolated masses throughout the specimen are altered andesine, which contains abundant, finely disseminated actinolite, muscovite, and clinozoisite grains. Near the right side of this specimen an irregular zone of dark-gray color peppered with white spots is typical granular nelsonite, composed of apatite and rutile. To the left of this zone, at the top, a very irregular veinlike area extending into the center of the specimen is dark-gray material that is almost pure apatite. This apatite zone in turn grades into a very irregular zone that sends fingerlike areas of apatite far into feldspar, which has been partly altered to clinozoisite and which shows as medium light-gray veinlets and irregular patches. Numerous light-gray veinlets extend throughout the specimen where clinozoisite has been formed along fractures. Small isolated areas of rutile (black) or rutile and apatite together are scattered through the specimen, and some of them occur entirely within andesine masses. Near the extreme upper side is an irregular residual area of highly altered feldspar enclosed in a nearly pure mass of apatite and rutile. Within this area are scattered nests of apatite and rutile. In this specimen the mineral relations are shown with great clearness and present an almost ideally perfect example of replacement.

Several small veins of nelsonite cut the anorthosite in one part of the mine of the American Rutile Co., and the relations of one of these are shown in plate $12, A$. The light-colored portion on each side is much-altered andesine, which is cut by a vein that is dominantly apatite but has ilmenite concentrated near the borders. Near the bottom of the specimen and extending diagonally upward from the lower right-hand corner of this vein is a branch veinlet of apatite and ilmenite, which has formed along a fracture that makes an angle of about $45^{\circ}$ with the major fracture. Numerous dark areas throughout the specimen represent ilmenite and a little associated apatite, which have replaced feldspar.

Small fragments of amphibolite nelsonite from the Bryant farm .on Allen Creek are composed largely of pyroxenes and amphiboles and lesser amounts of ilmenite and apatite but contain remnants of anorthosite, as shown in plate $13, A, B$, and $C$. These remnants occur as elliptical or augenlike areas that are commonly only a millimeter or two in length. They show extreme alteration and are bordered by conspicuous reaction rims of secondary minerals. The relations are similar to those shown in the hornblende nelsonite from the mine of the Southern Mineral Products Corporation, represented in plate $13, D$, and differ only in that in the latter replacement is a little less complete. In some specimens the reaction rim is a very finegrained aggregate of colorless garnet around feldspar, as shown in plate 13, $C$. Augenlike areas of garnet are abundant and probably represent replaced anorthosite. The pyroxene forms phenocrystlike areas, which have commonly been altered to fibrous hornblende, although some are still almost unaltered. The relations of amphiboles and biotite indicate that they are all secondary. The quartz occurs in small lenses and appears to be later than pyroxenes, although its replacement by amphiboles and biotite indicates that it is an early mineral. Apatite forms rounded grains that tend to be distributed in zones. Ilmenite occurs in fine grains, some of which are dustlike and are distributed in wisplike zones and lenses that give the rock a schistose habit, as shown in plate $13, A$. The zones cut across crystals of pyroxene and apatite, showing that they are later than these minerals.

In the rutile nelsonite on the Giles property the secondary minerals that have developed on the immediate contact with enclosing rock are dominantly sericitic muscovite, with very small amounts of chlorite and clinozoisite. There is a little coarsening of the grain size of sparse enclosed muscovite, but in general the sericite on the immediate contact is not different from that which has formed throughout the anor'hosite body. Also there has been no alteration or recrystallization of antiperthitic feldspar except for this formation of sericite. Thus there is no indication of high temperatures at the contact of rutile nelsonite with enclosing rock, and all the alteration is of the type characteristic of hydrothermal processes.

The gneissic country rocks, the border facies of the anorthosite, the oligoclase anorthosite, the lenses of hypersthene hornblende masses on the Bryant farm, the intrusive dikes, and the nelsonite amphibclites contained original iron-bearing minerals. Where these were invaded by titanium-bearing solutions the local supply of ferrous iron permitted the direct formation of ilmenite.

Watson and Taber ${ }^{30}$ have pointed out that the rutile nelsonite is confined to the anorthosite, whereas that in the country rock is invariably ilmenite nelsonite. On the other hand, in the disseminated deposits ilmenite occurs in and close to the shear zones that acter as feeders, but within short distances of such feeders preilmenite ferromagnesian minerals are absent and rutile becomes dominant. These relations show that the incoming solutions were deficient in iron, so that the ilmenite zones within the originally iron-free anorthosite were limited to close proximity to feeding channels, and away from these chamnels the nearly iron-free rutile was formed. The replacement of rutile by ilmenite and the direct formation of ilmenite where local supplies of iron were available show that ilmenite tended to be formed in preference to rutile wherever adequate ferrous iron was available.

In the rocks where a local supply of iron was absent, it is evident that in the intermediate zone rutile was formed first and was later more or less completely replaced by ilmenite. However, definite evidence is

30 Watson, T. L., and Taber, Stephen, op. cit. (Bull. III-A), p. 101. 
lacking for the inner zones where only ilmenite is now present. Here, for all that can be directly observed, ilmenite may have been formed as the primary titanium mineral. On the other hand, rutile may have been formed first and the process of replacement has gone to completion. However, the partial replacement of rutile by ilmenite and the formation of magnetite in minute fractures in ilmenite prove a sequence in the composition of the mineralizing solutions, with titanium, at least in part, preceding ferrous iron and iron persisting after titanium was greatly diminished or exhausted.

Solutions may possibly have carried both titanium and iron, and as the first wave penetrated the granulated feldspar the iron was quickly abstracted in the formation of iron-bearing minerals, after which rutile was formed. With continued flow of solutions the zone of depletion in iron may have gradually moved outward, so that iron-bearing minerals were formed farther and farther from the feeders. On this assumption, when solutions not yet impoverished in iron came into contact with rutile, it was replaced by ilmenite, the varying iron content of a single wave of solutions being the controlling factor in determining whether ilmenite or rutile formed. On the other hand, the most probable mechanism of segregation and transportation of titanium and iron and the sequence of their deposition seem to make an early vapor phase for titanium and a later liquid hydrothermal stage for ferrous iron the most probable assumption. (See pp. 33-37.)

A very general assumption has been that the titanium deposits were formed by a process of magmatic segregation. This assumption was perhaps based on the hard ores of the nelsonite that show the least direct evidence of replacement. However, it is obvious that any explanation of nelsonite must apply to all types, including the amphibolite-nelsonite. The presence of a large proportion of replacing minerals shows that the nelsonites containing them were not formed by a single intrusive process. It may be assumed that the earlier minerals (ilmenite, rutile, and apatite) were the result of magmatic segregation and that secondary minerals such as biotite were the product of later hydrothermal processes. Numerous occurrences show that ilmenite, rutile, and apatite have themselves invaded older minerals and indicate that all the minerals of nelsonite have been formed by the replacement of anorthosite.

Much of the nelsonite of the Roseland district contains a group of silicate minerals that are identical with those associated with the disseminated deposits. The nelsonite bodies of dikelike or veinlike character are intrusive into the anorthosite and so are definitely later than the anorthosite. If the disseminated deposits are magmatic they must have been formed together with the anorthosite. An origin of both types of deposits by magmatic segregation implies two distinct prriods during which titanium mineralization was active; the two could not have been formed together by magmatic segregation. On the other hand, magmatic segregation of the nelsonite occurring concomitantly with replacement in the anorthosite and the formation of its disseminated minerals implies two distinct modes of origin for like suites of minerals. Perhaps neither of these alternatives is impossible, but they seem very improbable.

\section{SUMMARY OF EVIDENCE OF ORIGIN}

The preceding sections have described the various rock types and mineral relations that indicate a secondary origin for the titanium and associatec minerals, and this evidence may now be briefly summarized.

The titanium and associated minerals are absent in the ungranulated primary feldspar and are confined to the granulated portions and so were introduced after the anorthosite crystallized. Ilmenite has replaced amphibole-pyroxene masses that have themselves replaced anorthosite. The secondary minerals show an erratic distribution and are most abundant in or near fractures capable of acting as feeders for incoming solutions. Swarms of minute minerals have formed entirely within single grains of feldspar, a relation commonly resulting from secondary reactions. The ilmenite, rutile, and apatite are ungranulated, although occurring in thoroughly granulated rock. The associated actinolite, tremolite, sericitic muscovite, garnet, and clinozoisite are a typically hydrothermal suit of minerals, clinozoisite and garnet probably being always secondary. The localization of iron-bearing minerals, with ilmenite, biotite, and actinolite near shear zones and nearly iron-free rutile and magnesian t"emolite at greater distances from feeders, presents a zonal relation indicative of formation by solutions. The formation of much of the ilmenite was controlled by local supplies of iron, and rutile was developed only where iron was absent, indicating mineralization during alteration of the enclosing rocks.

Ilmenite and the same group of associated minerals have been formed within the pre-anorthosite country rock near the contact. Abundant sphene formed in quartz monzonite at least a mile from the contact. The dike rocks that intrude the anorthosite contain ilmenite and clinozoisite. Ilmenite and quartz, or ilmenite and hornblende, have formed small veinlets in cleavage planes in clinohypersthene and so have invaded that mineral. Two distinct types of deposits s sem inconsistent with a pyrogenic origin, but not witl a replacement origin.

The mutual relations of the minerals of the Roseland region are shown in the accompanying table, which is arranged to show the succession of the minerals and the evidence pointing to this succession. 


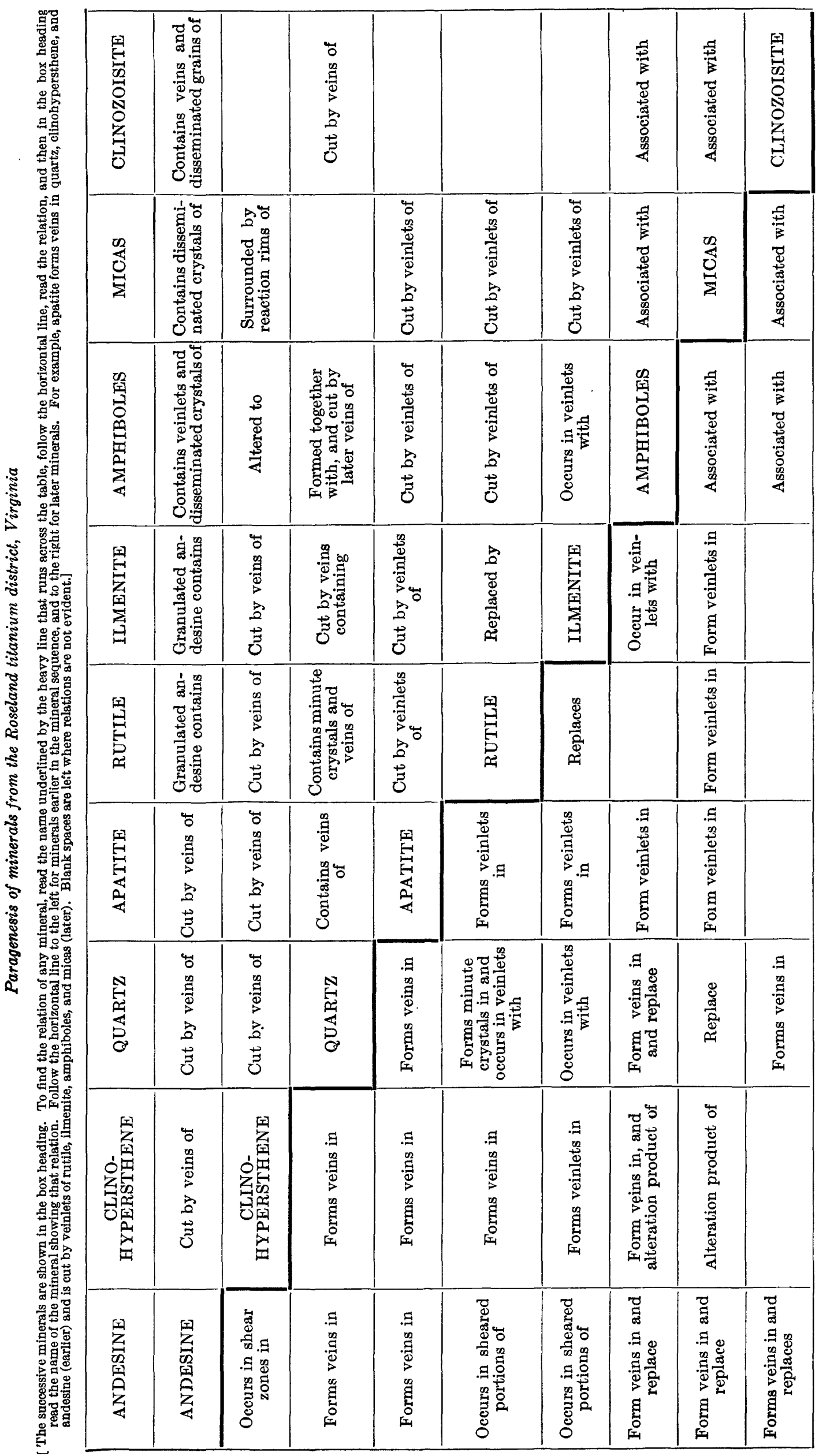





\section{RELATED TITANIUM DEPOSITS}

\section{ST. URBAIN, QUEBEC}

The titanium deposits of the St. Urbain area, Charlevoix district, Quebec, present marked similarities to those of the Roseland district of Virginia. Mawdsley ${ }^{31}$ describes the area as follows:

The small anorthosite boss within the St. Urbain map area is on the southeast margin of the belt of anorthosite masses extending through Quebec. This boss is oval in shape, with a major axis about 18 miles long and a minor axis of 9 miles. The major axis has a north and south direction and passes close to St. Urbain, which lies 3 miles within the anorthosite body. This ovoid area, except for a few deposits of ilmenite, is underlain, so far as known, only by anorthosite. The anorthosite varies in composition from place to place and ranges from a rock essentially composed of andesine $\left(A b_{70-65} A_{30-35}\right)$ to one essentially composed of labradorite $\left(\mathrm{Ab}_{44-35} \mathrm{An}_{56-65}\right)$. * * *

Large plagioclase crystals characterize the andesine anorthosite, and in many places the labradorite anorthosite appears formed of crushed large feldspars. ***

A nuarked feature of the contact between the anorthosite and the granite-diorite batholith is the foliated zone which follows the contact.

Several of those who have studied the deposit have concluded that the ore minerals were introduced as a magma. Osborne ${ }^{32}$ says, "The field and laboratory work show that the ores are not magmatic segregations but are magmatic injections." Mawdsley ${ }^{33}$ says, "It is the writer's opinion that they [ilmenite deposits] are magmatic in origin and were intruded as a liquid magma of essentially their present composition." On the other hand, Gillson ${ }^{34}$ concludes that they have been formed by hydrothermal processes. He says:

Horses of barren anorthosite are a common feature of all the ore deposits. They are of varying size and shape and in most cases have sharp boundaries, as do also the ore bodies themselves against their walls. All the horses show considerable evidence of hydrothermal action. * * *

The gangue minerals are the andesine of the original anorthosite, which is the only primary rock mineral found in any quantity in any of the slides examined, and the following minerals, which formed in the old rock by replacement: A mica close to phlogopite, apatite, tourmaline, rutile, sapphirine, quartz, spinel, zoisite, chlorite, sericite, serpentine, carbonate and zeolites. ***

The author concludes that the ores were formed by replacement in the already solid anorthosite and were deposited from solutions, either gaseous or liquid, which soaked through the rock. The ores are not pyrogenetic or orthotectic but were related to the anorthosite, in the sense that the solutions came from a reservoir in depth with which the magma that formed the anorthosite had previously been connected. The formation of the ores then belongs to the same general magmatic period as does the anorthosite, and the latter was still hot when the ore was formed. The following points can be tabulated as proving this conception:

31 Mawdsley, J. B., St. Urbain area, Charlevoix district, Qubec: Canada Geol. Survey, Dept. Mines, Mem. 152, Geol. ser., no. 133, pp. 18, 19, 29, 1927.

3? Osborne, F. F., Certain magmatic titaniferous iron ores and their origin: Econ. Geology, vol. 23, p. 921, 1928.

${ }^{33}$ Mawdsley, J. B., op. cit., p. 46.

34 Gillson, J. L., Genesis of the ilmenite deposits of St. Urbain, County Charlevoix, Q'uebec: Econ. Geology, vol. 27, pp. 554-577, 1932.
The ores are related to definite structural lines that developed after the solidification or approximately entire solidification of the anorthosite. $* * *$

The ores occur in many places in narrow veinlets or stringers that are many feet long in places, and in microscopic section can be seen to have followed along cracks and cleavage lines in other minerals, and large masses of old rock exist with disseminated ore in them. Such features could not have formed from a magma unless it had been an exceedingly tenuous one.

The ores have all the characteristics of replacement denosits. A definite paragenesis of minerals can be observed, which shows a sequence from a higher-temperature period to a lower-temperature period and indicates a long period of deposition. $* * *$

The writer believes that the large masses of disseminated ore are an especially firm proof of a deposition of the ore by solutions, once the conception of the contained ilmenite having formed by replacement is established.

This disseminated ore is original anorthosite, more or less replaced by phlogopite and ilmenite and their associates ar $d$ with the old feldspar riddled by chlorite and zeolites. The rassive ore differs from the disseminated ore only in the degree of roplacement. The horses are simply unreplaced remnants.

The paragenesis, so far as it could be established, was oligoclase, phlogopite; rutile, apatite, sapphirine, spinel, ilmenite, and probably quartz; sulfides, serpentine, chlorite, carl snate, and zeolites. The paragenetic sequence is considered to have been continuous and overlapping. Whether the emanations were gaseous or liquid is not known; probably they started out in a gaseous form and were completed as a liquid.

The conclusions of Gillson about the St. Urbain ores agree in all essential particulars with those of the writer about the ores of the Roseland district of Virginia-that is, in both areas the disseminated ores in the anorthosite as well as the segregated ores have been formed by hydrothermal replacement of anorthosite, and in both areas the ores are associated with a typically hydrothermal group of secondary mirerals.

\section{MAGNET COVE, ARKANSAS}

The Magnet Cove district of Arkansas, which has become a producer of titanium ores, was visited ly the writer in November 1937, in company with $\mathrm{I}^{\mathrm{T}}$. D. Miser and W. T. Schaller, of the United States Geological Survey, in order to compare the deposits with those of Virginia. Here one deposit is being actively mined, and prospecting has shown the wide occurrence of titanium ores at other places.

Magnet Cove has long been noted for its rare rock types and interesting minerals. These have been described in great detail by Williams ${ }^{35}$ in a report that is one of the classics of petrographic literatura, and later by Washington. ${ }^{36}$ The minerals have been discussed by many writers, and a few of the more rocent reports are those by Landes ${ }^{37}$ and by Landes, Parks, and Scheid. ${ }^{38}$

36 Williams, J.,F., Geol. Survey Ann. Rept. Arkansas for 1890, vol. 2, rn. 1-432, 1891.

30 Washington, H. S., Igneous complex of Magnet Cove, Arkansas, Grol. Soc. America Bull. vol. 21, p. 399, 1900; The foyaite-ijolite series, Magnet Cove, Ark., a chemical study of differentiation: Jour. Geology, vol. 9, p. 611, 1901.

${ }^{37}$ Landes, K. K., A paragenetic classification of the Magnet Cove minerals: Am. Mineralogist, vol. 16, pp. 313-326, 1931.

${ }^{38}$ Landes, K. K., Parks, Bryan, and Scheid, V. K., Magnet Cove, Ark.: 16th Internat. Geol. Cong. Guidebook 2, pp. 101-112. 1932 
The rocks of the Magnet Cove region are sedimentary, being shales, sandstones, and novaculite (a chertlike rock composed wholly of silica). The shales have been metamorphosed into slates during the intense folding that the region has undergone. The rocks are of Paleozoic age, and folding and metamorphism are believed to have taken place near the end of the Paleozoic era. The igneous rocks are of Cretaceous age and are subsilicic, being characterized by nepheline and in one of the dominant types by abundant pseudoleucite. These igneous rocks form a nearly continuous and roughly circular rim within which is a basinlike area about 2 miles' across known as Magnet Cove. Within this area exposures are sparse and discontinuous, but highly altered slate, novaculite, igneous rocks that have undergone marked secondary changes, and a very coarse grained calcite rock containing interesting secondary silicates have been recognized. Outside the basin, especially on the east and northeast, the sedimentary rocks show marked changes caused by magmatic solutions.

Titanium ores are being produced by the Titanium Corporation, of Malvern, Ark., from an area lying about 11/2 miles northwest of Magnet post office. Here the rocks are highly altered and deeply weathered, but the essential relations can be observed in the open cuts resulting from steam-shovel operations. The material in which the ores occur is a clastic aggregate composed of exceedingly varied rock types. This material is cut by dikes of ferromagnesian rocks, of which some are altered but others are fresh below the zone of weathering. The clastic material is made up of minor amounts of metamorphosed novaculite and slate, intermixed with igneous rock fragments-that is, it is a volcanic agglomerate. These fragments range in size from finely comminuted material to blocks 10 feet or more across. In much of the area exposed by mining operations, the fragments are set in a matrix that is now a fine-grained white clay. Microscopic study of the igneous material shows many rock types, only a few of which need be enumerated. The least-altered is a nearly pure orthoclase rock; others are partly altered plagioclase rocks and several types contain biotite. All show varying degrees of alteration to a beidellitelike clay mineral and to kaolinite. The white matrix shows well-preserved glassy volcanic tuff structure, although now completely altered to the clay minerals beidellite and kaolinite-that is, the material is now a bentonite. Thus the heterogeneous mixture of sedimentary and igneous materials is clearly pyroclastic in origin and was, no doubt, derived from an explosive volcanic vent in the immediate vicinity. Explosive volcanic activity has previously been recognized in southern Arkansas and in widely distributed localities in the Coastal Plain region ${ }^{39}$ but not before

39 Ross, C. S., Miser, H. D., and Stephenson, L. W., Water-laid volcanic rocks of early Upper Cretaceous age in southwestern Arkansas, southeastern Oklahoma, and northeastern Texas: U. S. Geol. Survey Prof. Paper 154-F, pp. 175-202, 1929. at Magnet Cove, although Featherstonehaush ${ }^{40}$ suggested such a possibility in 1836 .

The titanium minerals that occur here are dominantly rutile, with lesser amounts of brookite or pseudobrookite and a large proportion of so-called leucoxene. An X-ray examination of this material shows that it is anatase. Thus, the three crystal forms of $\mathrm{TiO}_{2}$, rutile, brookite, and anatase, have been recognized at Magnet Cove. These minerals occur in all types of rorks of the area, including the sedimentary rock fragments, and at least some of the intrusive dikes. Rutile se?ms to be most abundant in clastic materials and one of the most conspicuous occurrences is in the white l antonitic matrix that was originally a glassy volcanic tuff. Here it forms irregular crystals as much as 2 or 3 millimeters in diameter, which tend to occur in bunchy or streaklike friable aggregates that reach 2 or 3 centimeters in greatest dimension. The rutile is nearly black, much of it is coated with magnetite or encloses dustlike grains of magnetite.

Pyrite in crystals 1 centimeter in greatest diameter is abundantly associated with rutile in parts of the mine where operations have extended below the zone of oxidation, but above that zone the pyrite has been altered to limonite. It seems to be especially abundant in the material that was originally a glassy tuff.

All types of rocks making up the volcanic agglomerate contain abundant leucoxene, the amount reaching 50 percent of the rock in at least one sample. Some of the leucoxene is an alteration product of spher 9 , whose form it retains, but most of it is in irregular ereas that seem to have been formed directly by rep'acement. Leucoxene has been formed in the vesicular cavities in nearly all glass shards and locally has completely replaced them. It fills fractures in orthoclase or albite grains and is abundant on the cleavage planes of biotite and its alteration products. A few grains of biotite have been completely replaced, with retention of the micaceous structure. Some fine-grained volcenic rocks have been very thoroughly replaced, only isolated areas of the original rock remaining. Som e of the rocks are mixed with impurities, but others are pure masses of leucoxene 2 to 3 millimeters in diameter. Sharp-walled veinlets have been formed in many of the denser rocks.

The altered dikes contain smaller amounts of titanium minerals than the agglomerate, but titanite, rutile, and ilmenite are present and have been partly altered to leucoxene. Titanium minerals occur in association with pyrite in the altered dikes and were prc bably introduced into the dikes and agglomerates in the same manner.

The rutile in the sedimentary rocks and that associated with pyrite in the glassy tuffs affords evidence that they were introduced subsequent to the explosive

40 Featherstonehaugh, G. W., Geological report of an examination made in 1834 of the elevated country between the Missouri and Red Rivers: U. S. Canlogist Rept. to House of Representatives, p. 67, Washington, 1836. 
activity that produced this heterogeneous aggregation of rock materials. Rutile and pyrite in essential amounts have never been recognized as primary constituents of volcanic glass, and even if they could so occur, they could not be present in unbroken grains several millimeters in diameter and in aggregates several centimeters in length, associated with tuff shards at most a few tenths of a millimeter in greatest dimensions.

The alteration of all types of rock to clay minerals has been very thorough and extended below the level of present operations and below the zone of oxidation. This indicates that the alteration was not due primarily to weathering but was a part of the process of mineralization. The abundant introduction of leucoxene, which seems to have accompanied the development of clay minerals, tends to confirm the hydrothermal origin of both clays and leucoxene.

The other occurrence of titanium minerals is in an area extending from the vicinity of Magnet post office northward and eastward for a mile or more. Prospecting has been most extensive about 1 mile north of Magnet, but similar mineralization seems to have occurred over an area of 1 square mile or more. The principal titanium mineral in this general area is brookite, a form of $\mathrm{TiO}_{2}$, but pseudobrookite, a paramorph of rutile after brookite, is probably also present. In much of the area the mineralized rock was originally novaculite, which shows varying degrees of modification by mineralizing processes. Unaltered novaculite has a dense, chertlike texture and is composed of nearly equidimensional quartz grains, a few hundredths of a millimeter in diameter, that are without crystal form. In a road cut at Magnet metamorphism has increased the size of the quartz grains until the novaculite resembles a fine-grained sandstone, and much of it has become so friable that it can be crumbled in the hand. Here brookite and quartz have been developed as very beautiful euhedral crystals as much as 1 centimeter in length that project into geodelike cavities that have been formed locally in the novaculite. About a quarter of a mile southeast of Magnet quartz crystals as much as 1 foot in length have been collected, and brookite crystals may be picked up on the surface of the soil.

In the area about a mile north of Magnet the surface is littered with masses of quartz rock that have undergone varying degrees of recrystallization. Much of this material is now composed of euhedral quartz crystals that are eommonly doubly terminated and coated with beautiful euhedral brookite crystals. The quartz crystals are commonly a few millimeters in length, but specimens have been observed that reached 2 to 3 centimeters. The brookite crystals are in general about 1 millimeter in diameter and rarely exceed 2 or 3 millimeters. The masses of quartz associated with brookite are as a rule extremely porous and have seemingly lost as much as half their volume during recrystallization from the originally dense ncvaculite. The origin of this material would not be evident were it not possible to trace all degrees of recrystallization from normal novaculite through that which has been slightly recrystallized to coarse-grained masses of vuggy quartz.

In the area 1 mile north of Magnet, prospect pits that have reached a depth of about 50 feet show a rubblolike mixture of rock fragments in a matrix of clay materials. The clay materials, at least locally, form more than half the rubblelike aggregate. Near the surface the clay is red as a result of weathering and oxidation, but in depth nearly white taeniolite, dickite, and kaolinite are pre ent.

Even the small amount of material available from shallow prospect pits shows that the clay materials are at least in part the alteration products of volcanic ash. The rock masses of the rubblelike aggregate are dominantly quartz, but associated with these are smaller proportions of coarse-grained igneous rocks that wंere originally a nepheline syenite. The quartz is in part of the porous type above described and in part rounded boulderlike masses. The only remaining primary mineral of the igneous rock fragments is orthoclase of the sanidine type.

The quartz and igneous rock masses in this area rorth of Magnet seem to represent fragments that were blasted loose from underlying beds and deporited together with volcanic ash during periods of violent, explosive volcanic activity. These materials were subsequently subjected to intense secondary minerslization. The orthoclase of the nepheline syenite fragments is only partly altered to claylike minerals, but areas of nepheline are completely altered. The volcanic ash has completely changed to clay materials, and quartz fragments have been partly replaced by taeniolite and dickite. The clay minerals recognized are kaolinite $\left(\mathrm{Al}_{2} \mathrm{O}_{3} .2 \mathrm{SiO}_{2} .2 \mathrm{H}_{2} \mathrm{O}\right)$; dickite, which has the same composition; and beidellite $9 \mathrm{Al}_{2} \mathrm{O}_{3} \cdot 19 \mathrm{SiO}_{2} \cdot 6 \mathrm{H}_{2} \mathrm{O}$.$\mathrm{Na}_{2} \mathrm{O}$. Taeniolite $\left(\mathrm{KLiMg}_{2} \mathrm{Si}_{4} \mathrm{O}_{10}(\mathrm{~F}, \mathrm{OH})_{2}\right)$ is, at least locally, the most abundant secondary mineral. ${ }^{41}$ Brookite occurs in small grains throughout the rubblelike rock mass, and leucoxene is very abundant and shows the same evidences of secondary origin as at the rutile mine. The clay minerals kaolinite and beidellite are commonly the result of weathering processes, but more rarely have been formed in the presence of the"mal solutions at moderate temperatures, probably at a late state in hydrothermal alteration. Taeniolite has been formed most abundantly by the replacement of novaculite boulders but to a lesser extent by the replacement of glass or of nepheline. In the area 1 mile to the north, as well as at Magnet,. the formation of brookite in novaculite clearly records the introduction of titanium into an originally pure quartz rock. The brookite crystals perched on quartz crystals resulting from the

41 Miser, H. D., and Stevens, R. E., Taeniolite from Magnet Cove, Ark.: Am. Mineralogist, vol. 23, pp. 104-110, 1938. 
recrystallization of novaculite must also have been introduced by titanium-bearing solutions.

Thus two distinct areas in the Magnet Cove area show evidences of explosive volcanic activity, followed by mineralization that introduced titanium into originally titanium-free rocks. The large mineralized area, the introduction of so much new material, and the removal of great amounts of silica are evidences of large supplies of very active solutions.

Nearly 50 years ago Williams ${ }^{42}$ described the introduction of titanium into sedimentary rocks and made the following statement:

The brookite crystals are found only upon quartz and sandstones of the region included within the cover proper or the belt immediately adjoining it near Magnet post office, or lying loose in the soil where they have been left by the disintegration of the sandstone. * * * That they are directly referable to the metamorphic action of the syenite is beyond a doubt, since nowhere else in this extensive series of sedimentary rocks have any such crystals been found. *** The most plausible theory to account for the transformation of this element [titanium] from its original condition $* * *$ in the syenite, to that of brookite $* * *$ is that it was dissolved by the hot water and steam under pressure $* * *$ and was recrystallized $* * *$ when it reached the sandstone and quartz crystals. The titanium oxides may perhaps be considered as having been directly volatilized at the time of intrusion of the syenite and to have condensed as the dioxide directly, or else they may have been volatilized as the chloride of titanium and have been broken up on contact with the air and have formed the dioxide where it is now found.

Thus Williams clearly recognized this transfer of titanium from the parent igneous rock into the intruded rocks by hydrothermal or vapor phase processes.

Within the basinlike portion of the cove there is evidence of very thoroughgoing replacements that have introduced titanium, together with abundant other elements. Here both the titanium minerals (rutile and brookite) occur over wide areas, and locally perofskite $\left(\mathrm{CaTiO}_{3}\right)$ has developed in crystals reaching 1 centimeter on a side. The titanium garnets, melanite and schorlomite, with as much as about 21 percent of $\mathrm{TiO}_{2}$, are abundant in the rocks within the cove. However, exposures outside the area of active mining are too few and too discontinuous to permit an adequate study. In numerous areas the soil is littered with crystals of rutile, brookite, perofskite, magnetite, garnet, vesuvianite, nepheline, aegirite augite, apatite, and biotite and its alteration products vermiculite and chlorite. This float material probably represents only the minerals resistant to weathering and unfortunately tells but little about the exceedingly interesting geologic relations that must be concealed beneath the soil.

42 Williams, J. F., Arkansas Geol. Survey Ann. Rept. for 1890, vol. 2, pp. 322-324 1891.

\section{PHYSICOCHEMICAL PROCESSES CONTROLLING MINERALIZATION}

The geologic relations described in the foregoing pages present the basis for a consideration of the physicochemical processes that brought about the replacement of the anorthosite by titanium, phosphate, and silicate minerals. Such a consideraticn may be conveniently taken up in three parts-general theoretical background, segregation of mineralizing materials from the parent rock, and the chemistry of replacement. The segregation of materials preceded their deposition, which was by replacement of earlie" minerals. It seems best to consider replacement first, because its results are directly observable, as those of segregation are not, and because the chemistry of egregation is in part indicated by the chemistry of replacement.

\section{THEORETICAL BACKGROUND}

\section{STABHLITY OF MINERALS}

The solution, replacement, or alteration of a mineral in general implies that the mineral affected is unstable in its environment and that any new mineral formed is normally stable under that environment. It is recognized, however, that a mineral may persist almost indefinitely in an environment where it is potentially unstable - that is, in a metastable condition. It is also possible for a mineral of lower energy of formation to form first and later invert to the more stable form, or on the other hand, fail to invert - that is, remain in a metastable state. In other words, alteration or replacement of a mineral is in general evidence of its instability, but on the other hand absence of replacement is not necessarily evidence of stability.

Instability may be of several types. One is the result of an inherent instability that may be controlled by changes in temperature, pressure, or the chamical environment and is illustrated by the anorthite molecule discussed in the following section. A mineral may be inherently stable and yet be replaced by ore of lower solubility, as where calcium carbonate is replaced by magnesium or iron carbonates. Also an inherently stable mineral may be replaced by another, as a result of the mass-action effect resulting from a marked change in the concentration of the ions making up the chemical environment.

A change in the physical state of the system-from a liquid to a gas or vapor phase-does not necessarily cause a change in the stability relation, as has been pointed out by Fenner ${ }^{43}$ as follows:

43 Fenner, C. N., Pneumatolytic processes in the formation of minerals and ores: Ore deposits of the Western States (Lindgren volume), p. 80, Am. Inst. Min. Mte. ,Eng., 1933. 
According to a simple principle of thermodynamics, in a system consisting of solid, liquid, and gas, if the solid and liquid are in equilibrium, also the liquid and gas, then the solid and gas must be in equilibrium. It follows directly from this that if we have a fluid magma through which gases are rising, and if these gases form volatile compounds with the mineral matter of the magma or bring it into the gaseous condition in any manner, then (provided that there is equilibrium) any minerals crystallizing in the liquid portion of the magma will have their counterpart in minerals depositing from the gases at the contact.

However, the concentration of material in solution in the gas or vapor phase may be vanishingly small as compared with its concentration in the liquid phasethat is, the concentration may suddenly drop on a change from a liquid to a gas or vapor phase.

\section{REACTION PRINCIPLE}

A mineral relationship that exercises a control over the sequence of minerals through a definite order of transformation of one mineral into another has been described as the reaction principle by Bowen." Several reaction series as applied to igneous rocks have been described, but the mineral changes of the reaction type that have the most direct bearing on the replacement deposits observed in the Roseland district may be listed as follows:

(a) The stability of sodic plagioclase and the instability of calcic plagioclase in the presence of hydrothermal solutions.

(b) The instability of pyroxenes in the presence of a certain concentration of water-rich mineralizing solutions and the resulting tendency for their change to amphiboles.

(c) The stability of hydrous micas and their tendency to form at the expense of feldspar in the presence of water-rich solutions.

(d) The tendency for members of the epidote group to form from unstable calcic feldspars, pyroxenes, etc., in the presence of water-rich solutions.

Certain anhydrous minerals, such as quartz and garnet, may also form in the presence of hydrothermal solutions.

The ready albitization of calcic plagioclase has long been recognized on the basis of geologic observation, but Eskola ${ }^{45}$ has recently produced this change experimentally under a variety of laboratory conditions. He concludes: ${ }^{46}$

Anorthite heated under water-vapor pressure with soda and silica, either in the form of quartz or of an orthosilicate with excessive carbon dioxide from sodium bicarbonate, was changed into albite-rich plagioclase. The spilite reaction could thus be reproduced.

A general feature of the results is that the reaction and recrystallization was more complete when the temperature was

44 Bowen, N. L., The evolution of the igneous rocks, pp. 54-62, Princeton Univ. Press, 1928.

4s Eskola, Pentti, An experimental illustration of the spilite reaction: Soc. géol. Finland Comptes Rendus, Extr. no. 9, pp. 1-8, Helsinki, 1935.

10 Idem, p. 8

$286089-41-3$ below the critical point (of water) than when it was above the same point. Thus the experiment at $550^{\circ}$ rendered less well developed crystals than that at $360^{\circ}$. Best of all vas the result at temperatures between $310^{\circ}$ and $330^{\circ}$.

Furthermore, it may be noted that only experiments 2, 10, and 11 , at the lowest temperatures, varying from $264^{\circ}$ to $331^{\circ}$, gave pure albite, whereas the experiments at $360^{\circ}$ or higher temperatures, up to $550^{\circ}$, gave oligoclase or even andesine. This seems to mean that only albite but no anorthite, not even as isomorphic mixtures, is stable at temperatures up to $335^{\circ}$ or a little more.

Bowen ${ }^{47}$ makes the following statement about the alterations produced by a high concentration of water:

In the presence of a high concentration of hyperfusibles, principally water, the ordinary minerals of a gabbro (pyroxene and plagioclase) become unstable - that is, liquids of that nature are saturated with other phases and will transform pyroxene and plagioclase into these other phases to an extent limited by the amount of reacting materials available. The instability of the plagioclase is characterized by the fact that the one end member, albite, remains stable in contact with the liquid, whereas the other end member enters into new combirations. The result is albitization of some of the plagioclase which , theoretically, should be accompanied by at least a little albite newly deposited from the liquid. The calcic molecule of the plasioclase may in part enter, together with pyroxene material, into the constitution of the hydrous phase, amphibole. There will thus be a little new-formed amphibole accompanied by transformation of some pyroxene into amphibole (uralite). Under other conditions the calcic molecule of the plagioclase forms the hydrous zoisite or, acquiring iron from pyroxene, the related epidote, and, instead of amphibole, chlorite may appear. The only feature of these reactions that has any suggestion of simplicity is the great stability of albite. The results of the action of these last residual liquors in basic magmas are then albitization, uralitization, saussuritization, chloritization, and epidotization, all occurring as late magmatic processes.

This albitization (the formation of $\mathrm{NaAlSi}_{3} \mathrm{O}_{8}$ at the expense of anorthite $\left(\mathrm{CaAl}_{2} \mathrm{Si}_{2} \mathrm{O}_{8}\right)$ is not a simple exchange of bases (that is, an exchange of $\mathrm{Na}_{2} \mathrm{O}$ for $\mathrm{CaO}$, for albitization involves an increase in the $\mathrm{SiO}_{2}$ (or removal of $\mathrm{CaO}$ and $\mathrm{Al}_{2} \mathrm{O}_{3}$ ) and a substitution of a univalent base for a bivalent one. Therefore, when a calcic plagioclase is unstable there is an opportunity for the formation of other minerals besides albite, those formed being the combined result of the new materials available in the altering solution and those expelled from the unstable mineral.

\section{RELATION BETWEEN ALKALIES AND ALUMINA}

The normal order of crystallization in a deep-ssated, slowly crystallizing magma is for ferromagnesian minerals and calcic plapioclase to precede orthoclase and quartz, although a little highly sodic plagioc'ase is commonly late, and the experiments of Eskola suggest that it may belong to the deuteric stage of formation. The purely residual portions of magmatic solutions commonly contain silica and alkalies, together with concentrated hyperfusibles and at times a wide variety of rare elements. The widespread geologic evidence of

47 Bowen, N. L., Ore deposits of the Western States (Lindgren volume), p. 114, Am. Inst. Min. Met. Eng, 1933. 
alkalic minerals formed in the late deuteric stages of the crystallization of an igneous rock, in pegmatites derived from it, and in contact-metamorphic deposits where sericite may be abundant, shows a strong tendency for alkalies to be concentrated into the residual solutions. This evidence is so general that we must look for a cause in the normal differentiation processes of a crystallizing magma. The relation between $\mathrm{Al}_{2} \mathrm{O}_{3}$ and alkalies seems to be an important controlling factor in this process. The feldspars, feldspathoids, and micas are the minerals that commonly fix essential amounts of alkalies, as these alkalic aluminous silicates are notably insoluble, whereas most of the non-aluminous alkalic salts are relatively soluble or unstable.

The magma may not have originally contained enough $\mathrm{Al}_{2} \mathrm{O}_{3}$ to fix quite all the alkalies, as feldspar or mica; or the early formation of aluminous pyroxenes and amphiboles may leave the last residual material deficient in $\mathrm{Al}_{2} \mathrm{O}_{3}$. The complete quantitative relation between alkalies and $\mathrm{Al}_{2} \mathrm{O}_{3}$ is not shown by a chemical analysis of the final crystallized product of that magma - that is, of the igneous rock seen today, after the loss of most of the hyperfusible constituents that it contained and of the solutes carried with them as they escaped. If $\mathrm{Al}_{2} \mathrm{O}_{3}$ is deficient, the $\mathrm{K}_{2} \mathrm{O}$ and $\mathrm{Na}_{2} \mathrm{O}$ tend to remain in solution in the residual material of most crystallizing magmas. There are, of course, exceptions to this tendency, for in some types of hydrothermal solutions alumina, alkalies, and silica remain in solution together. The formation of adularia is one example, and another is the formation of alunite $\left(\mathrm{K}_{2} \mathrm{O} .3 \mathrm{Al}_{2} \mathrm{O}_{3} .4 \mathrm{SO}_{3} .6 \mathrm{H}_{2} \mathrm{O}\right)$ under some conditions. However, these relations indicate that very commonly the presence of alkalies in a magma residuum may be correlated with the removal of most of the $\mathrm{Al}_{2} \mathrm{O}_{3}$ during the normal crystallization of the parent rock, so that the escaping solutions carried but little $\mathrm{Al}_{2} \mathrm{O}_{3}$. This relation probably explains the analytical evidence that the secondary minerals in the anorthosite of the Roseland district derived their alumina largely from the replaced feldspar. Thus the chemistry of differentiation explains the observed results of mineral replacements that did not involve a transfer of $\mathrm{Al}_{2} \mathrm{O}_{3}$. The alkalies remaining in solution in the magma residuum may have partly escaped with it, provided there was no opportunity for them to react with earlier minerals of the parent rock. The proportion of alkalies thus thrown into the residual solutions need not be great to enable them to have an important effect during the late deuteric, vein-forming, and contact-metamorphic reactions produced by those solutions.

The concentration of sodium in the residuum of many crystallizing magmas is shown by the albitization of both potassic and calcic feldspars. This may be slight, as where very narrow reaction rims are formed around older feldspars or where small amounts of sodic micropegmatite or myrmekite are formed at the ex- pense of the feldspars. On the other hand, it may be very great, as where large masses of rock are albitized..$^{48}$ The replacement of microcline by albite $\mathrm{t}$ as been an essential process in the development of a great number of pegmatites and shows that essential amounts of $\mathrm{Na}_{2} \mathrm{O}$ are commonly present in the solutions that escape from a parent magma into the pegmatite during the later stages of pegmatite formation. This roplacement of potassic by sodic feldspar appears to be most commonly a simple process of base exchange by which sodium is abstracted from the replacing solutions and potassium restored to them. Several factors, such as mass action, greater solubility of albite than of microcline, and instability of microcline, might cause replacement of microcline by albite. However, albitization of small amounts of potassic feldspars is not rare in rocks where only deuteric processes appear to have been active. Where such a replacement occurs in a dominantly potassic rock, an excess of sodium over potassium sufficiently higll to cause mass action seems improbable. For these reasons a real in tability of microcline in the presence of hydrothermal solutions at moderately low temperatures seems prokable.

The presence of sodium and a deficiency of potassium in replacing solutions derived from a rock th at contains potassic feldspar indicate that at some earlier and perhaps pyrogenic stage of crystallization potassic feldspars were stable and had been formed in preference to sodic feldspars and thus sodium was concentrated in the residuum. The later abstraction of sodium from this residuum during the albitization of potassic feldspars indicates a reversal of the stability relations of sodic and potassic feldspars between the time (pyrogenic?) when potassic feldspars were first formed and the time (hydrothermal?) of later albitization. Although the field evidence for such a reversal of stability between potassic and sodic feldspars is widespread, the physicochemical basis for such a change is not understood. ${ }^{49}$ Plagioclase may also be partly replaced by muscovite, and so potassium may again be abstracted from the residual solutions.

\section{PHYSICAL CHARACTER OF REPLACING SOLUTIONS}

The effects of the boiling and later conc'snsation of the residual portion of a crystallizing magma have been described by Bowen ${ }^{50}$ as follows:

It has been stated that present in the liquid are $\mathrm{H}^{+}, \mathrm{Na}^{+}$, $\mathrm{K}^{+}, \mathrm{Fe}^{+++}$, and a number of other positive ions, together with $\mathrm{Cl}^{-}, \mathrm{F}^{-}, \mathrm{S}^{--}, \mathrm{OH}^{-}$, and all the possible acids, bares, and salts that these can form. In deciding upon which of these shall dominate in the vapor phase let us arbitrarily single out certain equilibria for consideration. We have in such solutions an equilibrium between $\mathrm{KCl}, \mathrm{H}_{2} \mathrm{O}, \mathrm{HCl}$, and $\mathrm{KOH}$, and all of them are to be regarded as present in at least some small proportion.

48 Bailey, E. B., and Grabham, W. G., Albitization of basic plarioclase feldspars; Geol. Mag., vol. 6, pp. 250-256, 1909. Gilluly, James, Keratophyres of eastern Oregon and the spilite problem: Am. Jour. Sci., 5th ser., vol. 29, pp. 225-252, 1935.

${ }^{49}$ Bowen, N. L., personal communication.

so Bowen, N. L., op. cit. (Lindgren volume), pp. 119, 123, 124. 
If a vapor forms in equilibrium with this liquid, which of these will enter more freely into the vapor? Certainly not $\mathrm{KOH}$. $\mathrm{H}_{2} \mathrm{O}$ and $\mathrm{HCl}$ will be the principal constituents of the vapor, though it will no doubt contain some $\mathrm{KCl}$. Again arbitrarily, we may single out the equilibrium between $\mathrm{Na}_{2} \mathrm{~S}, \mathrm{NaOH}, \mathrm{H}_{2} \mathrm{~S}$, and $\mathrm{H}_{2} \mathrm{O}$. It is plain that in so far as determined by this equilibrium, $\mathrm{H}_{2} \mathrm{~S}$ and $\mathrm{H}_{2} \mathrm{O}$ will dominate in the vapor. If another equilibrium, that between $\mathrm{SiO}_{2}, \mathrm{HF}, \mathrm{SiF}_{4}$, and $\mathrm{H}_{2} \mathrm{O}$, is considered, we note that $\mathrm{HF}, \mathrm{SiF}_{4}$, and $\mathrm{H}_{2} \mathrm{O}$ will enter dominantly into the vapor. In the actual complex solution these equilibria are not independent of each other, but this fact need not obscure what the net result will be. The vapor formed by the boiling of the alkaline residual liquors of magmas will be acid, in that it contains an excess of $\mathrm{HCl}, \mathrm{HF}, \mathrm{H}_{2} \mathrm{~S}, \mathrm{CO}_{2}, \mathrm{H}_{3} \mathrm{BO}_{3}, \mathrm{H}_{2} \mathrm{SO}_{4}$, and other more or less volatile acids. ***

In an actual example the vapor formed at any point will move only a short distance before it encounters a cooler environment, where it is partly or wholly condensed, becoming a part of the liquid there existing. Though a full and accurate analysis of such a complex situation is not possible, it seems necessary to suppose that a mass of intrusive rock and its envelope, containing interstitially and in fractures a pegmatitic liquid that is experiencing "second boiling," will constitute itself a fractional-distillation column. Throughout this column there occurs a liquid through which gas bubbles slowly rise and suffer selective (fractional) condensation. Close to the boiling source the liquid will be continually enriched in the hyperfusible constituents that are relatively nonvolatile; at points more and more remote the liquid will become increasingly richer in those hyperfusible constituents that are more volatile-water, various halogen compounds including acids, and other substances already suggested as prominent in the vapor phase. $* * *$

The vapor that boils off from a crystallizing solution, say an ordinary salt solution, is in equilibrium with the liquid and with the crystals; in other words, it is saturated with the crystals and would not attack them in any way so long as it remained a vapor. But let the vapor be condensed at lower temperature, and the liquid obtained will be wholly out of equilibrium (unsaturated) with the same crystals and will therefore attack and dissolve them.

Niggli ${ }^{51}$ has assigned great importance to mineralization processes occurring above the critical temperature and has based a classification of mineral deposits on this assumption. However, Morey, ${ }^{52}$ Fenner, ${ }^{53}$ and Bowen, ${ }^{54}$ who are engaged in detailed experimental studies of geophysical problems, have all pointed out that supercritical conditions need not be assumed, and indeed there are valid reasons for doubting the assumption that such conditions have exerted a general control of geologic processes. Fenner ${ }^{55}$ says:

It is possible that at all stages during the cooling of a magma the residual liquid holds enough dissolved material so that the critical temperature appropriate to it always lies above that prevailing at the time. The critical temperature of an aqueoigneous silicate solution is by no means that of pure water but is higher by an amount depending upon the quantity of dissolved material. Intrusive magmas and the residual liquids derived

\footnotetext{
${ }^{61}$ Niggli, Paul. Ore deposits of magmatio origin-their genesis and natural classification, trans. by H. C. Boydell, London, Thomas Murby \& Co., 1929.

${ }^{2} 2$ Morey, G. W., Relation of crystallization of the water content and vapor pressure of water in a cooling magma: Jour. Geology, vol. 32, pp. 291-295, 1924.

53 Fenner, C. N., Pneumatolytic processes in the formation of minerals and ores: Ore deposits of the Western States (Lindgren volume), Am. Inst. Min. Met. Eng., p. $72,1933$.

64 Bower, N. L., The broader story of magmatic differentiation briefly told: Idem, p. 116.

ss Fenner, C. N., idem, p. 72.
}

from them doubtless have moderate to very high vapor pressures and are able to distill vapors into the pores of enclosing rocks, but that does not imply in any way that the supercritical conditions postulated by Niggli obtain. The critical temperature of a liquid under pressure is that at which it loses its meniscus and passes continuously, without change of composition and without absorption of latent heat or discontinuity of any kind, into a vaporous form which tends to expand into all the space available to it. With respect to the more aqueous residual solutions derived from magmas such conditions are theoretically pcssible, but they do not of necessity appear, and it is hardly safe to assume their existence without definite evidence.

\section{On the same subject, Bowen ${ }^{56}$ says:}

Niggli has treated the subject especially in its bearing on the formation of mineral deposits. He likewise concluded that under deep-seated conditions the external pressure would be adequate to prevent boiling, but that, as further concentration of volatile constituents goes forward during crystallization, critical phanon:ena will be exhibited. This is, in its theoretical aspects at least a very different matter from boiling, though whether any practical criteria can be adduced whereby its results might be distinguished from those incident to boiling is not so certain. The distinction lies in the fact that when critical phenomena occur only one phase is present other than the solid phases. This phase is developed from the liquid phase by a process involving no discontinuity in change of properties, though it is in many of its properties a gaslike phase. The familiar differences between gas and liquid no longer exist under critical conditions. In the case of boiling, two distinct phases are present in addition to the solid phases, and they can be definitely referred to as liquid and gas.

The great quantities of material introduced and the almost incredible volume of gases or vapors required to remove the great quantities of material that have disappeared from the replaced rock-all these have prevented field observers from accepting some of the theoretical conclusions about vapor- or gas-phase deposition in several types of ore deposits. In other deposits a vapor-phase deposition seems prokable. Moreover, a vapor-phase may play a dominant role in the segregation of mineralizing materials even where the geologic evidence seems to preclude deposition by such a phase.

The mechanism by which a volatile phase $m \varepsilon, y$ be segregated and its subsequent history are outlined in the foregoing quotations from the work of Bowen. Under some conditions the greater part of the volatiles of the residual material may boil, but probably more commonly only a part boils at points where temperatures are highest or pressures are reduced, and this vapor phase rises as a stream of bubbles through a column of liquid. In either event the vapor-phase will condense where brought into a region of lower temperature. As the acid radicals- $\mathrm{F}, \mathrm{Cl}, \mathrm{SO}_{3}, \mathrm{CO}_{2}$, and $\mathrm{P}_{2} \mathrm{O}_{5}-$ are more volatile than bases, they will tend to be concentrated in the vapor phase and a liquid phase derived from it. The new acid liquid phase formed by condensation of the vapor phase, or a phase that had remained partly liquid but had become acid by condensation within it of the vapors in a rising stream of

${ }_{56}$ Bowen. N. L., op. cit., p. 116. 
bubbles, will be out of equilibrium with the crystal phase of the parent rock and will tend to dissolve its bases or the bases of any rock traversed so long as the acid character persists. The least stable minerals in contact with it will be first attacked, and in general these are ferromagnesian and calcic silicates, such as olivines, pyroxenes, and calcic plagioclase.

\section{SOURCE OF FERROMAGNESIAN MATERIALS}

The normal crystallization sequence in deep-seated igneous rocks is ferromagnesian minerals and calcsoda feldspars followed by alkalic feldspars and quartz; and this tends toward the early depletion of the residual magma in ferromagnesian materials and calcium. Nevertheless, there is widespread geologic evidence for the introduction of great quantities of ferromagnesian and calcic materials during hydrothermal stages of mineralization in a wide variety of mineral deposits. The writer ${ }^{57}$ has given reasons for believing that ferromagnesian constituents, although originally in large part abstracted during an early magma stage of crystallization, may subsequently be restored to the residual solutions of the same magma by a deuteric process of base exchange or mineral replacement.

A large proportion of all igneous rocks show evidence of deuteric reactions that would tend to release bases to the residual solutions. Certain ferromagnesian minerals are unstable in the presence of an excess of hot hyperfusibles, and the change from a nearly anhydrous to a water-rich environment-commonly the concentration of $\mathrm{H}_{2} \mathrm{O}$ in the residuum through crystallization of anhydrous minerals - tends to cause the alteration of olivine to serpentine and of pyroxenes to amphiboles. The albitization of calcic plagioclase or its replacement by muscovite in the presence of residual solutions carrying alkalies will release calcium, which in turn tends to react with orthorhombic pyroxenes to form amphiboles and release $\mathrm{MgO}$ and $\mathrm{FeO}$ according to the following equation:

$$
\begin{gathered}
8\left[(\mathrm{Mg}, \mathrm{Fe}) \mathrm{O} . \mathrm{SiO}_{2}\right]+2 \mathrm{CaO}+\mathrm{H}_{2} \mathrm{O} \rightarrow\left[\mathrm{H}_{2} \mathrm{O} .2 \mathrm{CaO} .5(\mathrm{Mg}, \mathrm{Fe})\right. \\
\left.\mathrm{O} .8 \mathrm{SiO}_{2}\right]+3(\mathrm{MgO} . \mathrm{FeO}) .
\end{gathered}
$$

On the other hand, the alteration of diopsidic pyroxene would tend to fix $\mathrm{MgO}$, and release $\mathrm{CaO}$. However, orthorhombic pyroxenes are much less stable than diopside. If calcic feldspars are abundant and are undergoing alteration, these reactions may give a dominance of $\mathrm{CaO}$ in the residual solutions, but if there is a large proportion of orthorhombic pyroxene undergoing alteration the $\mathrm{CaO}$ niay be largely used up in deuteric reactions within the parent rock, so that little escapes, and $\mathrm{MgO}$ and $\mathrm{FeO}$ become dominant in the escaping solutions.

\section{CHEMISTRY OF REPLACEMENT}

Igneous rocks are commonly composed of diverse groups of minerals with widely differing and but poorly understood stabilities. These minerals may be altered or replaced under the influence of solutions whose composition is in general inadequately known. T/hen such a rock is subjected to alteration, the relations are so complex that the chemistry of the processes $c^{\wedge} n$ be only approximated. In contrast, the Roseland anorthosite was originally an almost pure feldspar rock that contained only $\mathrm{SiO}_{2}, \mathrm{Al}_{2} \mathrm{O}_{3}, \mathrm{CaO}, \mathrm{K}_{2} \mathrm{O}$, and $\mathrm{Na}_{2} \mathrm{O}$ in essential amounts. This rock was altered by solutions that introduced $\mathrm{TiO}_{2}, \mathrm{Fe}_{2} \mathrm{O}_{3}, \mathrm{FeO}, \mathrm{MgO}$, and $\mathrm{P}_{2} \mathrm{O}_{5}$ in essential amounts, and small quantities of $\mathrm{F}, \mathrm{Cl}, \mathrm{CO}_{2}$, and rarer materials. These relations present ar opportunity for determining the chemistry of the replacement of feldspars and the development of secondarr silicates. It does not present an equal opportunity for determining the chemistry of the replacement by rutile, ilmenite, and clinohypersthene, as they appear to Jave been formed by the complete removal of feldspar and the deposition of entirely new materials in their stead. The record of the steps in the replacement have thus been obscured and there is, therefore, little that forms a basis for determining the chemistry of the process.

The formation of clinohypersthene was a local episode that was followed by one during which the entire anorthosite mass anJ the contact rocks were mineralized. This is represented by the formation of apatite, rutile, ilmenite, quartz, amphiboles, micas, and clinozoisite and presents an unusual opportunity for the study of replacement processes. This replacement was effected by mineralizing solutions and is believed to have been a nearly continuous process, although there was no doubt a sequence in mineral formation, whish reflects changes in the composition and physical character of the solutions.

The disseminated deposits show zonal re'ations, as ferrous iron minerals (ilmenite, actinolite, and biotite) are limited to close proximity to feeding channels, and outside of this is a zone in which low-iron tremolite recording the introduction of $\mathrm{MgO}$ was formed in association with rutile, sericitic muscovite, and clinozoisite. In the outermost zones clinozoisite and sericitic muscovite were formed without the introduction of new materials other than $\mathrm{H}_{2} \mathrm{O}$ and a little $\mathrm{F}$ and $\mathrm{CO}_{2}$. These zonal relations indicate that the bases reprosented in the secondary minerals tended to drop out of the incoming solutions, although with much overlapping, in the order $\mathrm{FeO}, \mathrm{TiO}_{2}, \mathrm{MgO}, \mathrm{CaO}, \mathrm{K}_{2} \mathrm{O}$, and $\mathrm{Na}_{2} \mathrm{O} . \mathrm{Fe}_{2} \mathrm{O}_{3}$ was also added, but its place in the order of deposition is not clear, although the formation of magnatite veinlets in ilmenite indicates that the degree of oxidation of iron was greater in the later stages. The relations indicate that the $\mathrm{CaO}$ and $\mathrm{Na}_{2} \mathrm{O}$ were derived almost wholly from andesine undergoing alteratior, and the $\mathrm{K}_{2} \mathrm{O}$ was probably in part derived from microcline.

The zonal distribution of the secondary minerals is not sharply limited, for the continued flow of solutions

\footnotetext{
${ }^{67}$ Ross, C. S., Origin of the copper deposits of the Ducktown type in the southern Appalachian region: U. S. Geol. Survey Prof. Paper 179, pp. 52-54, 1935.
} 
caused one mineral zone to overlap another, but they contribute to an understanding of the physical chemistry of replacement processes. In the following discussion, the mineralogic and chemical changes are considered in the order indicated by these zonal relations.

Some of these minerals (the micas, for instance) do not have a fixed chemical composition, but the following representative formulas may be used, as variations from them would only change the proportions slightly but not the essential relations. For simplicity of calculation the formulas are expressed in the form of oxides.

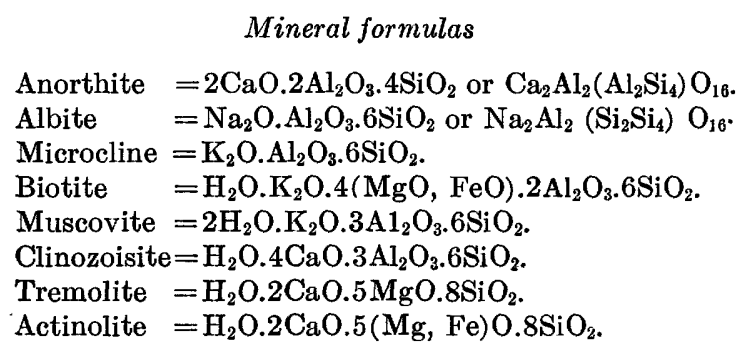

It should be noted that the formula for anorthite as commonly written $\left(\mathrm{CaO} . \mathrm{Al}_{2} \mathrm{O}_{3} .2 \mathrm{SiO}_{2}\right)$ corresponds to only one-half of the formulas for albite and microcline, and therefore the anorthite formula has been doubled.

The feldspar undergoing alteration was andesine, an isomorphous mixture of approximately 1 part of anorthite to 2 parts of albite, associated with about a part of antiperthitic microcline- that is, about $\mathrm{Ab}_{2} \mathrm{An}_{1} \mathrm{Or}_{1}$.

Water, being the most abundant solvent, was also present in excess, but as this solvent water occurs on both sides of the equations, it can be neglected, and only the water that enters directly into the chemical reactions need be included. Other hyperfusibles that may have accelerated but did not take part in the reactions have also been neglected. Andesine expressed as 2 parts of albite plus 1 part of anorthite appears on the left side of the equations, and the new albite released by reaction appears on the right. In the same way microcline may appear on both sides of the equations. These are not canceled, because the prin ary feldspar had a fixed composition, and it seems advisable to include the complete feldspar composition of the reacting materials rather than only the unstable and reacting part of the feldspar. To do so would obscure the mineralogic relations, which are as essential as the chemical relations for presenting a clear picture of the reactions involved. The alteration of plagioclase is not

but is

$$
\text { anorthite } \rightarrow \text { clinozoisite, etc. }
$$

$$
\text { andesine }\left\{\begin{array}{l}
2 \text { albite } \\
1 \text { anorthite }
\end{array}\right\} \rightarrow \text { albite +clinozoisite, etc. }
$$

That is, albite is just as much a secondary product of reaction as clinozoisite and the related minerals.

In the following equations the mineral formulesboth before and aftem the reaction-represent observed minerals whose chemical composition is closely known, whereas the amounts of the solutes added or abstracted during the reaction are deduced through a balancing of the equations. In order to present the transformation as clearly as possible, the names of the minerals involred are given directly below their chemical formulas.

The reactions near the zone where $\mathrm{FeO}$ and $\mathrm{MgO}$ were available in the solutions and biotite and actinclite were formed can be represented by the following equation:

Equation 1 represents the inner zone of most intense alteration. The new elements introduced form only about 10 percent of the resulting rock, although there has been a very thorough change in the mineral composition.

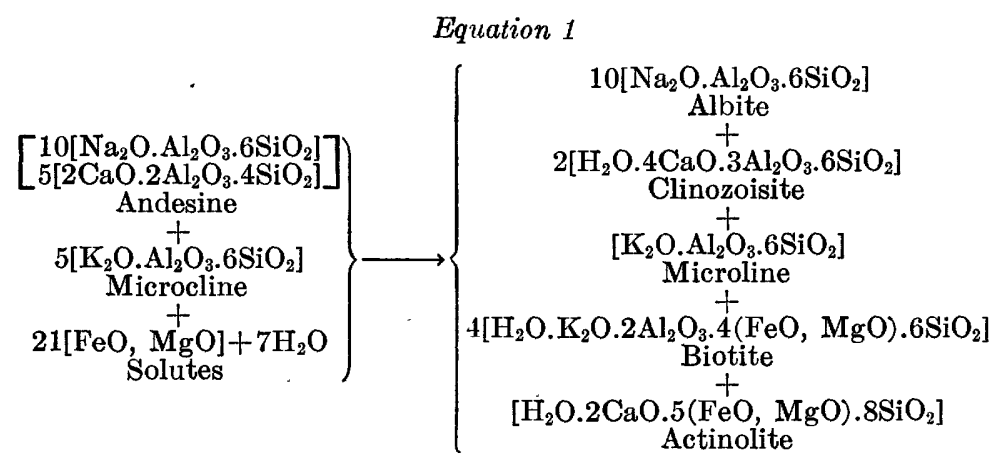

Ilmenite also was formed in this zone, but it should be noted that equation 1 does not express the reactions resulting from its introduction.

Equation 2 represents the intermediate zone where about 2.5 percent of new material has been added and a slightly smaller proportion of new minerals developed than in the zone represented by equation 1 . 
Equation

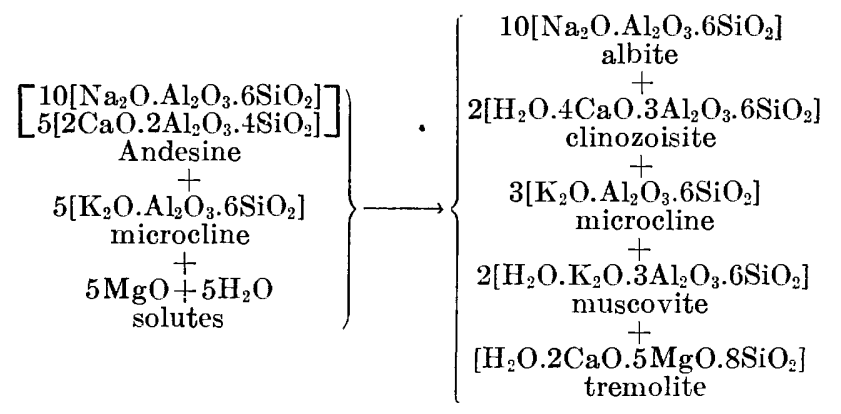

This is the zone characterized by rutile, but, as in $\mid$ would tend to release $\mathrm{Na}_{2} \mathrm{O}$ in the zones of most intense equation 1 , the introduction of $\mathrm{TiO}_{2}$ is not represented.

The microcline has tended to resist alteration, while $\mathrm{K}_{2} \mathrm{O}$ has been introduced, at least locally. The formation of sericitic muscovite at the expense of andesine replacement. This tendency is illustrated $\mathrm{ky}$ another slight modification of equation 2 and is shown in equation 3.

Equation 3

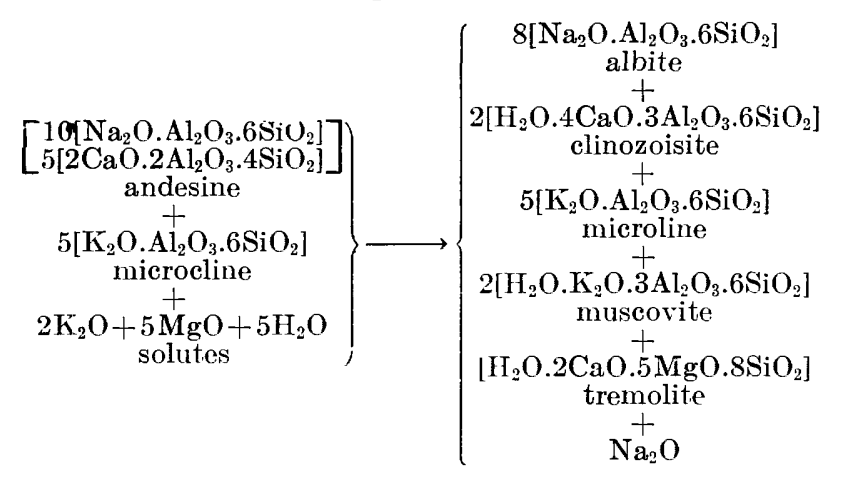

The $\mathrm{Na}_{2} \mathrm{O}$ released by the replacement shown in and the $\mathrm{CaO}$ released from the replaced feldspar equation 3 migrated but a short distance before reacting with andesine to produce albite (albitization). This process also involved the introduction of some $\mathrm{SiO}_{2}$, (anorthite molecule) formed clinozoisite. $\mathrm{T}$ 'is type of replacement is shown in equation 4.

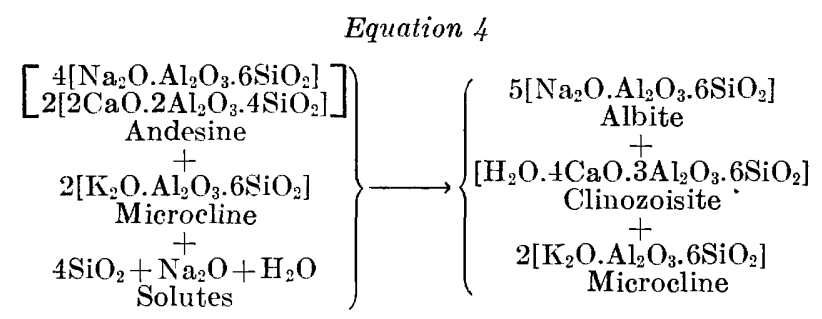

Equation 5 represents relations throughout the the primary rock. Albite and the elements that anorthosite. Here only a little water was introduced, recrystallized into clinozoisite were released from the and a marked change in mineral composition was andesine, and some of the microcline formed muscovite. caused merely by a rearrangement of the materials of.

\section{Equation 5}

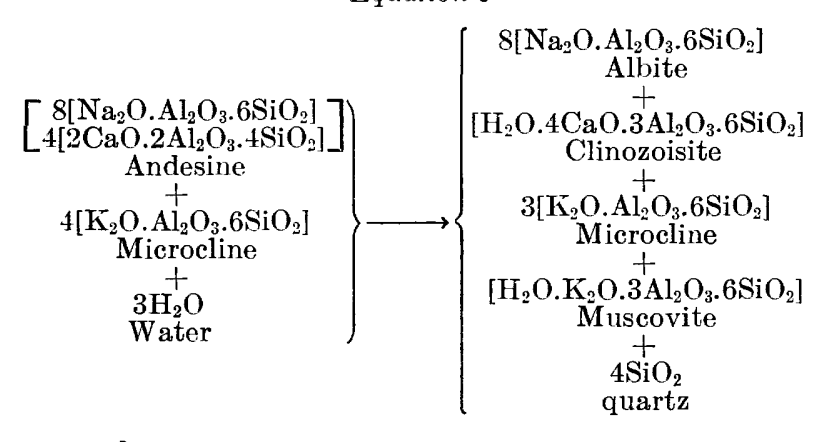


These equations, for the sake of simplicity, have assumed complete alteration of the unstable anorthite molecule to new minerals. Actually only part of this molecule was altered, and varying proportions of it, together with corresponding amounts of albite and microcline, should appear on both sides of the equations. Thus plagioclase represented by various proportions of anorthite and of albite molecules should appear on the right-hand side of the equation and would vary from albite $\left(A b_{93} A b_{7}\right)$ in zones of most intense alteration to andesine $\left(\mathrm{Ab}_{67} \mathrm{An}_{33}\right)$ where alteration was slight.

These long equations could have been represented by several shorter ones. For instance, the alteration of anorthite to clinozoisite could be represented as a single reaction releasing $\mathrm{Al}_{2} \mathrm{O}_{3}$ and $\mathrm{SiO}_{2}$. Then microcline could be represented as partly altering to muscovite and at the same time combining with the released $\mathrm{Al}_{2} \mathrm{O}_{3}$. However, it is believed that the method of representation used gives a clearer picture of the changes, and the fact of the transfer of elements from one mineral to another will be understood. Clinozoisite, muscovite, and tremolite commonly formed evenly disseminated microscopic grains within the altered feldspar. Thus most of the movement was so local that diffusion within the solid cyrstals was adequate for the transfer. The most static radical was evidently $\mathrm{Al}_{2} \mathrm{O}_{3}$, and probably $\mathrm{Na}_{2} \mathrm{O}$ was the most mobile and migrated farther from its place of release than any of the other materials. Some $\mathrm{CaO}$ and no doubt some $\mathrm{K}_{2} \mathrm{O}$, however, escaped into the surrounding rocks to form calcite and sericite.

The preceding equations doubtless do not present a perfect picture of the chemical processes that took place in the anorthosite; but it seems evident that modifications would not change the essential relations but change only slightly the proportions. The volume relations are not shown by the equations. However, such new minerals as micas, amphiboles, and clinozoisite have a greater density than the feldspar replaced and would tend to compensate the volume relations resulting from the introduction of materials. The use of specific gravities of the minerals given in standard textbooks makes it possible to calculate closely the relative volumes of the old and new minerals. Such calculations indicate that the mineral transformations represented in equation 1 , where about 10 percent of new material was added, would result in an increase in volume of only about 2 percent. All the other equations would represent a loss of volume. As alteration was rarely as complete as represented in equation 1 , the general effect would be a loss rather than a gain in volume.

Notwithstanding obvious qualifications, the equations agree so completely with the actual mineral transformations that they seem to give an essentially correct picture of the chemical changes that controlled replacement in the Roseland anorthosite. The equations also indicate the chemical reason for the formation of two or more minerals-usually a mica and an amphibole or clinozoisite - during a single stage of alteration of the andesine. The materials released by the replacement process could not recrystallize into a single new mineral. and two or three new ones were formed.

The equations serve to show that the introduction of no new material except $\mathrm{H}_{2} \mathrm{O}$ and a very little $\mathrm{F}$ need be assumed in explaining alterations in the outermost zone of mineralization in the anorthosite. For this reason it seemed advisable to have an analysis mede of the highly altered rock, to compare with an analysis of the primary feldspar which had previously been made. A specimen containing a very large proportion of muscovite and clinozoisite was obtained fron the quarry of Dominion Minerals, Inc., on the Piney Piver, and the analyses of this and the primary feldsper are given below.

Chemical analyses of fresh and altered feldspar

[J. G. Fairchild, analyst]

\begin{tabular}{|c|c|c|}
\hline & Fresh & Altered \\
\hline 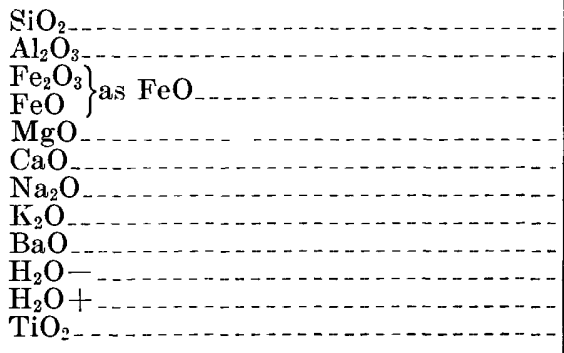 & $\begin{array}{r}61.44 \\
23.47 \\
.20 \\
.05 \\
\text { 5. } 00 \\
5.94 \\
\text { 3. } 92 \\
.19 \\
.03 \\
.20 \\
.10\end{array}$ & $\begin{array}{r}59.62 \\
24.06 \\
.49 \\
.09 \\
.07 \\
4.54 \\
5.47 \\
4.53 \\
.03 \\
1.19 \\
.09\end{array}$ \\
\hline & 100. 54 & 100. 18 \\
\hline
\end{tabular}

The two analyses are surprisingly similar when it is remembered that the second one represents a very great change in mineral composition. There has been a small loss of $\mathrm{CaO}$ and $\mathrm{Na}_{2} \mathrm{O}$ and a gain in $\mathrm{K}_{2} \mathrm{O}$. This change is to be expected from the tendency for $\mathrm{K}_{2} \mathrm{O}$ to become fixed at the expense of $\mathrm{Na}_{2} \mathrm{O}$, as discussed on page 27 and represented in equation 3 . The limited ability of $\mathrm{FeO}$ and $\mathrm{MgO}$ to travel far from feeding channels is also shown by the analyses. Ferric iron has been slightly increased in the altered rock and proxies $\mathrm{Al}_{2} \mathrm{O}_{3}$ in clinozoisite.

\section{SOURCE AND CHARACTER OF THE SOLUTIONS}

The processes going on at the source of mineralizing solutions can never be observed directly. However, evidence about the early history of escaping solutions may be gained from their effects on the invaded rocks, as interpreted in the light of chemical and geophyrsical experiment.

The parent magma supplying introduced materials undoubtedly underwent progressive crystallization in depth and tended to concentrate hyperfusibles in its residuum. When these reached a certain concentrstion 
and pressure they tended to escape, carrying with them certain soluble materials. The minerals deposited indicate that the escaping solution carried the bases $\mathrm{FeO}, \mathrm{TiO}_{2}, \mathrm{MgO}, \mathrm{Fe}_{2} \mathrm{O}_{3}$, some $\mathrm{K}_{2} \mathrm{O}$ and $\mathrm{SiO}_{2}$, but probably only minor amounts of other bases.

The greatest concentration of any hyperfusible other than water is the $\mathrm{P}_{2} \mathrm{O}_{5}$ of apatite. However, apatite contains essential amounts of fluorine (2.5 percent) and a little chlorine. The more widely distributed sericitic muscovite and even the clinozoisite (see p. 12) contain small amounts of $F$, and the total amount in the Roseland rocks probably exceeds the more localized amount in apatite. The dominance of fluorine over chlorine is shown by the composition of the apatite. (See p. 14.) No barite was formed, although the presence of barium is shown by the feldspar analysis. (See p. 10.) Therefore, $\mathrm{SO}_{3}$ was probably not present in essential amounts in the solutions, although the sparse but widely distributed pyrite and pyrrhotite show that sulfur was present in some form during a late stage of mineralization. The occurrence of calcite shows the presence of $\mathrm{CO}_{2}$ in the mineralizing solutions, and graphite indicates that carbon was locally introduced in some unknown form. Thus the hyperfusibles that may have played a part in the segregation and transfer of mineralizing materials appear to be $\mathrm{H}_{2} \mathrm{O}$, $\mathrm{P}_{2} \mathrm{O}_{5}, \mathrm{~F}$, and a little $\mathrm{Cl}$ and $\mathrm{CO}_{2}$.

\section{MODE OF SEGREGATION AND TRANSPORTATION OF MINERALIZING MATERIALS}

\section{PHOSPHORUS}

Apatite, with about 40 percent of $\mathrm{P}_{2} \mathrm{O}_{5}$, is abundantly present in the nelsonite bodies and locally in the disseminated deposits and appears to have been one of the earliest minerals to be formed during the mineralization of the anorthosite. It was preceded only by the pyroxene and some of the quartz. Therefore, phosphorus seems to have been selectively segregated from the parent magma during the earlier, hotter stages of the evolution of mineralizers.

Apatite is one of the earliest minerals to be formed during the magmatic stage of the crystallization of igneous rocks and is stable at very high temperatures. Thus the formation of apatite tends to remove $\mathrm{P}_{2} \mathrm{O}_{5}$ from the magma at an early stage of crystallization, at a time when the concentration of $\mathrm{P}_{2} \mathrm{O}_{5}$ is very low.

The chemical composition of a wide variety of igneous rocks shows that $\mathrm{P}_{2} \mathrm{O}_{5}$ is almost always present as one of the acid radicals, and yet phosphate minerals are commonly sparse in mimeral deposits formed by magmatic solutions. Therefore, $\mathrm{P}_{2} \mathrm{O}_{5}$ is probably not normally a member of the group of materials that tend to be concentrated in a hyperfusible rich magma residuum. This indicates that in the rare type of deposits where apatite is abundant, some mechanism of segregation difierent from that occurring in most mineral deposits was active. Perhaps a later reaction with early products of crystallization re eased $\mathrm{P}_{2} \mathrm{O}_{5}$ and restored it to the residual solutions after water and other hyperfusibles had reached a high derree of concentration.

An acid vapor phase seems the most probable mechanism for the removal of phosphorus from the parent rock, as the apatite of the nelsonite bodies was introduced by solutions in some form. A vapor phase composed dominantly of $\mathrm{H}_{2} \mathrm{O}$ enriched in acid radicals, asdescribed on pages 28,29 , would probably tend to keep $\mathrm{P}_{2} \mathrm{O}_{5}$ in solution or to break down apatite and release $\mathrm{P}_{2} \mathrm{O}_{5}$. Very little is definitely known about the behavior of phosphorous compounds at high temperatures and pressures, but phosphorous acid is moderately volatile. Many of the compounds of $\mathrm{P}_{2} \mathrm{O}_{5}$ studied at low temperatures are reported to break down in the presence of water, or at only moderately high temperatures. However, the very high pressures that must have existed at the profound depths at which $\mathrm{P}_{2} \mathrm{O}_{5}$ was segregated would, in general, increase the range of stability, so that most compounds would remain stable at temperatures higher than those ordinarily studied. Several combinations of phosphorus with the other materials of a vapor phase are possible. However, no information on phosphorous compounds is available the.t permits a definite prediction of the compounds that would dominate a vapor phase under high pressur $\mathrm{s}$, and it is therefore not possible to sta te any definite boiling point. Even though this were moderately high, the partial pressure effect would permit an excess of vrater vapor to carry over essential amounts of phosphorous compounds, provided they were stable in its presence. This would probably imply distillation of a tapor phase of $\mathrm{P}_{2} \mathrm{O}_{5}$ at higher temperatures and probably its escape at an earlier stage of crystallization than that characterizing most mineral deposits.

A liquid-phase extraction of $\mathrm{P}_{2} \mathrm{O}_{5}$ seems improbable for the following reasons. A residual solution that has remained in a liquid phase throughout its history has been in contact with easily alterable ferromagnesian and alkalic minerals and so must have remsined essentially neutral. Apatite seems to be stable in such a medium, and any $\mathrm{P}_{2} \mathrm{O}_{5}$ tending to remain in solution would be in an environment rich in calcium and iron minerals and could immediately react with them to form very insoluble compounds of these elements.

The sharp restriction of apatite to nelscnite bodies or to small veinlike areas in the anorthosite, while other calcium minerals were formed outside of these areas, suggests that the development of apatite was more dependent on supplies of $\mathrm{P}_{2} \mathrm{O}_{5}$ than of $\mathrm{CaO}$. This tends to confirm the evidence, which is more conclusively presented by the silicate minerals and analyses of fresh and altered rock, that local supplies were the main source of $\mathrm{CaO}$. However, some of the $\mathrm{CaO}$ of the nelsonite highest in apatite was probably introduced 
or locally concentrated from other parts of the anorthosite undergoing alteration.

\section{TITANIUM}

The chemistry of the segregation of titanium presents a complex problem, but an essential one in the paragenesis of the titanium deposits. As pointed out on page 34 , the hyperfusibles that need to be considered as possible mediums of transfer are $\mathrm{H}_{2} \mathrm{O}, \mathrm{P}_{2} \mathrm{O}_{5}, \mathrm{~F}$, and a little $\mathrm{Cl}$ and $\mathrm{CO}_{2}$.

First we may examine the probable reactions of titanium with these acid radicals in a liquid phase. Titanium phosphate is very insoluble in neutral solutions, and so $\mathrm{TiO}_{2}$ and $\mathrm{P}_{2} \mathrm{O}_{5}$ were probably not introduced together, and this is confirmed by the mineralogic evidence that apatite was earlier than rutile and ilmenite. No titanium carbonates are known, and potassium titanic carbonate, though soluble, probably is not stable at high temperatures in the presence of water, so that $\mathrm{CO}_{2}$ probably played no part in producing a soluble form of titanium. The alkali titanites are probably not stable, for although they are soluble, they are broken down into insoluble hydroxides on boiling.

Ilmenite is promptly precipitated in the presence of ferrous iron minerals, as shown by the restricted zone of ilmenite in the Roseland area. It is also shown in the diabase at Goose Creek described by Shannon. ${ }^{58}$ Here a normal diabase and a diabase pegmatite are characterized by titanium-bearing pyroxene. In parts of the diabase pegmatite this pyroxene has been altered to a paler variety and the titanium released to the solutions, which migrated out into the normal diabase. Here it came into contact with disseminated magnetite and was precipitated as aggregates of hematite and ilmenite, so that it was removed from solution before it had moved more than 20 or 30 centimeters from its source. Therefore it seems probable that if titanium in some soluble form entered a liquid phase while in direct contact with the varied minerals of a ferromagnesian rock, there would be a ready opportunity for it to combine with $\mathrm{FeO}$ to produce insoluble titanium minerals. This is what happened when titanium-bearing solutions entered the ironbearing rocks now exposed, and the same reactions may be supposed to have occurred in deeper-seated rocks. That is, geologic evidence indicates that titanium is precipitated in the presence of ferrous iron under a wide range of physical conditions, and it seems improbable that titanium was segregated, transported, and deposited in the presence of $\mathrm{FeO}$ by a solution that remained in a liquid phase throughout its history.

A vapor phase of titanium seems capable of explaining a segregation of titanium from rocks with a normal

${ }^{58}$ Shannon, E. V., The mineralogy and petrology of intrusive Triassic diabase at Goose Creek, Loudon County, Va.: U. S. Nat. Mus. Proc., vol. 66, art. 2, no. 2539, pp. 1-86, 1924.

$286089-41-4$ iron content. Titanium characterizes many ferromagnesian igneous rocks and may be present as disseminated ilmenite, as sphene, or as titaniferous pyroxenes. However, no primary, undoubtedly pyrogenic rocks appear to be known in which iron is not in large excess over titanium. Therefore it seems difficult to pisture a truly pyrogenic process of magmatic differentiation that would result in the excess of titanium over iron. On the other hand, a fluorine-rich vapor phase that distilled titanium over together with but little ferrous iron seems to be a logical mechanism for bringing s.bout a high concentration of titanium from a parent rock in which iron and titanium were present in ncrmal proportions.

The solutions that introduced titanium minerals into the sedimentary rocks of the Magnet Cove region of Arkansas were emanations from igneous rocks of the immediate vicinity, or from more deep-seated rocks similar to those exposed at the surface.

The following analyses ${ }^{59}$ represent two typical Magnet Cove rocks:

Analyses of Magnet Cove rocks [H. S. Washington, analyst]

\begin{tabular}{|c|c|c|}
\hline & 1 & 2 \\
\hline 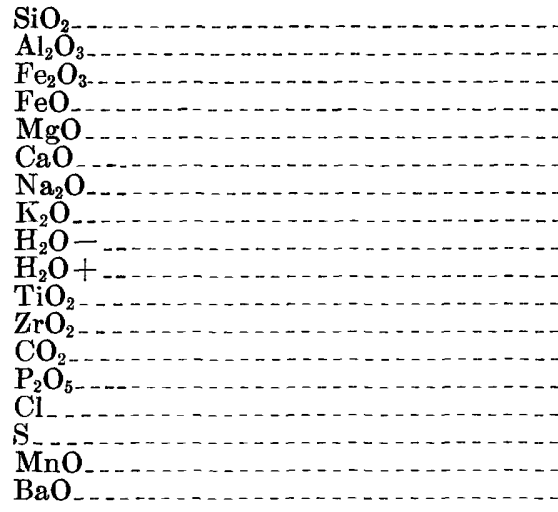 & $\begin{array}{r}41.75 \\
\text { 17. } 04 \\
6.35 \\
3.41 \\
4.71 \\
\text { 14. } 57 \\
6.17 \\
\text { S. } 98 \\
.28 \\
.62 \\
.58 \\
.05 \\
\text { None } \\
1.09 \\
\text { None } \\
\text { Trace } \\
\text { None }\end{array}$ & $\begin{array}{r}53.09 \\
21.16 \\
1.89 \\
2.04 \\
.32 \\
\text { 3. } 30 \\
6.86 \\
8.42 \\
.24 \\
1.13 \\
.11 \\
.04 \\
.82 \\
.15 \\
.02 \\
.08 \\
.20 \\
.61\end{array}$ \\
\hline & 100.60 & 100. 48 \\
\hline
\end{tabular}

Locally, rocks higher in $\mathrm{TiO}_{2}$ are present in. the Magnet Cove region, but many of these show evidence of post-magmatic alteration, and have clearly been enriched in titanium. Another rock from Mrgnet Cove analyzed by Washington ${ }^{\mathrm{B} 0}$ had probably been enriched in titanium and contained $\mathrm{TiO}_{2} 4.54$ persent, total iron 15.24 percent, and $\mathrm{FeO} 6.17$ percent.

The analyses show the preponderance of total iron and also of ferrous iron over titanium. In one the total iron is nearly 17 times as abundant as titanium and in the other 36 times. In a third analysis (not shown in the table), which had probably been enriched in

s9 Washington, H. S., Igneous complex of Magnet Cove, Ark.: Geol. Soc. America Bull., vol. 21, p. 399, 1900; The foyaite-ijolite series, Magnet Cove, Ark., a chemical study of differentiation, Jour. Geology, vol. 9, p. 611, 1901.

60 Washington, H. S., Jour. Geology, vol. 9, p. 620, 1901. 
titanium, this element was 5 times as abundant as iron. Notwithstanding this excess of iron, the hyperfusibles escaping from these rocks, deposited abundant titanium minerals. Locally, titanium minerals were formed almost to the exclusion of iron mineralsthat is, physico-chemical forces were at work that resulted in a selective concentration of titanium from a rock in which iron was many times as abundant as titanium.

Titanium tetrachloride is relatively volatile, with a boiling point of $136^{\circ} \mathrm{C}$. at atmospheric pressure, but is so readily hydrolyzed in the presence of water that its volatilization in the laboratory is possible only under carefully controlled anhydrous conditions. Titanium tetrafluoride has a higher boiling point than the tetrachloride, $285^{\circ}$ at atmospheric pressure. It also tends to hydrolyze under normal temperatures and pressures but less strongly than the tetrachloride.

The tendency for the tetrafluoride to hydrolyze raises a question as to the possibility of the formation of a vapor phase in the presence of water. However, it seems probable that hydrolysis would tend to be inhibited under the very high pressures and the accompanying high temperature that must have existed in the very deep-seated pre-Cambrian parent rock. The titanium deposits may well have formed at a depth of several miles, and the parent magma of the mineralizing solution must have lain still deeper. The boiling point of titanium tetrafluoride under these deep-seated conditions would probably be raised to about the figure that is to be inferred at the time an early vapor phase was escaping from a crystallizing magma.

Another factor that would tend to inhibit hydrolysis of titanium at high temperatures has been pointed out by Burbank. ${ }^{61}$ Any vapor phase must have been in intimate contact with ferromagnesian, aluminous, and alkalic minerals of the parent rock and the rocks traversed during its escape. These minerals and especially feldspars, pyroxenes, and olivine would themselves have a strong tendency to hydrolyze and so remove water from the system, especially as their abundance would exert a strong mass-action effect. The hydrous minerals micas and amphiboles form and are able to remove water from the system in even typically pyrogenic rocks, where the water concentration must be very low. In the Roseland district micas, amphiboles, and clinozoisite have formed throughout the anorthosite, in the ferromagnesian dikes, and probably also in the parent rock of which they are apophyses. This must have resulted in a large removal of water from the mineralizing medium. There is, then, evidence that seems to make it probable that titanium was segregated as a vapor phase of titanium tetrafluoride, which was distilled over from the residual solution of a partly crystallized parental magma.

os Burbank, W. S., personal communication.
Were adequate amounts of $\mathrm{F}$ present to $\mathrm{k}$ 'ing about such a transfer? The $\mathrm{F}$ in the apatite cer ${ }^{+}$ainly does not represent any such amounts, but the minute percentages in sericitic micas and clinozoisite, which are present throughout the anorthosite mass; must be large in the aggregate, and the quantity of $F$ that undoubtedly escaped into contiguous rocks was doubtless larger still. The amount of $\mathrm{F}$, therefore, was evidently far in excess of that required to trinsport all the titanium, which after all is local in its occurrence.

The titanium deposits at Magnet Cove, Ark., present mineral relations that seem not inconsistent, with such an origin. Here titanium has been carried far into a pure quartz sedimentary rock, and ta eniolite, a mineral carrying 13 percent of $F$, has formed abundantly. The same medium that introduced titanium removed a large proportion of the silica and recrystallized the remainder into comparatively large euhedral quartz crystals. A vapor phase rich in fluorine ssems a not improbable explanation of these relations.

As the magma cooled the temperature must have fallen below the boiling point of one after another of the constituents of a vapor phase. As the boiling point of titanium tetrafluoride was evidently rather high, that constituent may have practically disappeared from the system at an early stage. Of course, if any material of higher volatility continued to boil off, it v'ould carry with it a certain amount of material of lowe volatility, owing to the partial pressure effect. There would not be an entirely sharp elimination of any volatile constituent as the temperature dropped below its boiling point, although there probably would be a very sudden drop in its concentration. If a liquid phase became dominant titanium probably almost ertirely disappeared from the escaping solutions.

\section{IRON, MAGNESIUM, AND CALCIUM}

The chemical conditions that would permit the segregation of iron are intimately connected with its relation to titanium and to magnesium and calcium. The acid radicals that should be considered are the same as those for titanium-that is, $\mathrm{H}_{2} \mathrm{O}, ?_{2} \mathrm{O}_{5}, \mathrm{~F}, \mathrm{Cl}$, and $\mathrm{CO}_{2}$.

Ferrous iron salts of all these radicals have very low vapor pressures, and those of magnesium snd calcium are even lower. This would not inhibit their presence in a vapor phase, but their segregation in essential amounts in the vapor phase seems imprchable. On the other hand, the transportation of ferrous iron bicarbonates or halogens in a liquid phase is quite possible. The conditions for the volatilization of ferric halogens are more favorable, as ferric chloride vaporizes at $280^{\circ}$ and the fluoride at about $1,000^{\circ}$, atmospheric pressure. However, chlorine seems not to have beer abundant, and the vapor pressure of the fluoride is rather high. Therefore, the concentration of ferric iron in a vapor 
phase was probably low, although it was probably present, and it may have been augmented by the partial pressure effect. Thus a large volume of gas may have been the segregating if not the transporting agent for the ferric iron that forms a small part of the widely disseminated clinozoisite. However, a liquid phase as a source seems possible, especially as magnetite, with its higher $\mathrm{Fe}_{2} \mathrm{O}_{3}$ content was formed in a later and probably cooler stage than ilmenite, in which the iron is in the ferrous state. The geologic relations also show that $\mathrm{FeO}$ and $\mathrm{MgO}$ were introduced together, but probably not by a liquid-phase solution that also contained $\mathrm{P}_{2} \mathrm{O}_{5}$ or $\mathrm{TiO}_{2}$.

Some calcite is present in the border facies of the anorthosite, in the adjacent country rock, and in the pegmatitelike zones. The $\mathrm{CaO}$ of this calcite may have been introduced together with the $\mathrm{MgO}$ and $\mathrm{FeO}$ of the ferromagnesian silicates, as the greater solubility of $\mathrm{CaCO}_{3}$ would favor its migration to greater distances from the feeding channels, where the lower temperatures might permit the formation of a carbonate. However, the analyses given on page 33 show that the solutions tended to remove rather than introduce $\mathrm{CaO}$, and it seems probable that the $\mathrm{CaO}$ in these outer zones was released from the altered andesine.

The approximate absence of $\mathrm{CaO}$ in solutions that were introducing $\mathrm{FeO}$ and $\mathrm{MgO}$ may be due to the stability or the sparsity of calcium minerals in the parent rock. A much more probable explanation, however, is the removal of $\mathrm{CaO}$ from the solutions before or during their escape, as a result of the extensive alteration of the hypersthene type of pyroxenes to amphiboles described on page 30 .

\section{RESTATEMENT OF PARAGENESIS}

The foregoing considerations indicate that the most probable sequence and mode of segregation of the mineralizing materials of the Roseland anorthosite was as follows: The $\mathrm{P}_{2} \mathrm{O}_{5}$ of the apatite, together with smaller proportions of $\mathrm{F}$ and a very little $\mathrm{Cl}$, was concentrated as a vapor phase that distilled over at high temperature and pressure. This may have reached the point of deposition as a vapor phase or condensed and completed its journey as an acid liquid phase. The calcium of apatite was probably derived either locally or with slight transportation from the calcium feldspar of the replaced anorthosite. Slightly later, titanium also was distilled over as a vapor phase of titanium tetrafluoride at comparatively high temperature and pressure. As cooling progressed, a liquid phase became dominant, and ferrous iron and magnesium materials characterized by very low vapor pressures but moderate solubilities in a liquid phase were segregated from the parent rock. The earliest of the ferrous iron, which reacted with rutile to form ilmenite and formed ferromagnesian silicates, may have been carried in so'ution in part as a halogen salt, but, at least during the later stages of mineralization, ferrous iron and magnesium may have been transported as bicarbonates.

Calcium is normally concentrated slightly hofore magnesium and ferrous iron, as it is the most soluble of the three carbonates. The conditions within the source rock, however, were such that very little calcium escaped, and that released through the alteration of plagioclase was probably fixed within the parent rock by the alteration of pyroxenes to amphiboles. Small amounts of $\mathrm{CaO}$ were probably derived from the anorthosite, rather than from the parent ferromagnesian rock, and locally concentrated. Silica was not sharply limited to a single stage of mineralization, and most of it was probably derived from the alteration of the anorthosite itself. The period of introduction of ferric iron is not clearly indicated, nor is its mode of segre. gation clear, but it is widely distributed in the anorthosite far from the active feeding channels, where a moderate temperature and a liquid phase are prolıble, though a gas-phase segregation from the parent rock is possible.

The foregoing outline of the most probable physicochemical processes controlling the segregation of the mineralizing materials of the Roseland district from their parent magma is obviously a tentative explar ation of a difficult problem in mineral paragenesis. The chemical reactions of phosphorus and titanium in particular under high pressures and temperatures have not been studied. Experiments that would add greatly to our knowledge of the chemical reactions of thes 3 elements and others of interest to students of ore deposits are possible, but the complex chemical environment and the physical conditions in a very deep-seated crystallizing magma can probably never be duplicated experimentally. It is evident that there are serious gans in the fundamental knowledge required for a complete and rigorous explanation of the paragenetic procisses. Many essential chemical and physical data are lacking, and mineralogic and geologic observations are only partly informative, as they do not reach to the deeper zones and can never directly reveal processes. For these reasons, speculative studies seem to be a legitimate mode of approach to the problem, provided both the writer and the reader clearly understand that the picture set forth is a tentative one.

The first test of any suggested paragenesis, of course, is whether it gives a consistent picture of the processes under consideration in the particular region, but a more rigid test is its applicability by other students to other 
areas. The explanation must agree with geologic relations and physicochemical knowledge and must be checked by experiment wherever possible. If studies such as these are applied to numerous mineral provinces and modified where necessary to fit the geologic and physicochemical picture, the serious gaps in studies by direct observation and experiment may be gradually filled in, and an acceptable story of minoralization processes built up, step by step. It is therefore as a trial approach to the intricate problems of mineral paragenesis that the foregoing study of the segregation of mineralizers has been presented. 
PLATES 1-19 


\section{PLATE 1}

\section{POLISHED SPECIMENS FROM THE MINE OF THE AMERICAN RUTILE CO. SHOWING RELATION OF PARTLY}

GRANULATED FELDSPAR TO RUTILE

All natural size. Note the absence of rutile (round black grains) in the primary feldspar (gray material) in all the specimens.

$A$. The dark-gray areas represent primary feldspar; they are all in uniform optical orientation and so represent resicual areas of a single crystal. White, fine-grained, granulated feldspar has formed along fractures.

$B$. The granulation is more complete than in $A$, and the residual areas of primary feldspar are more isolated; but all are in uniform optical orientation. The greater granulation has been followed by the introduction of more rutile.

C. Rounded residual areas of primary feldspar with abundant rutile in the granulated parts.

$D$. Almost solid rutile (black) encloses residual areas of primary feldspar that shows a few small patches of granulation. 

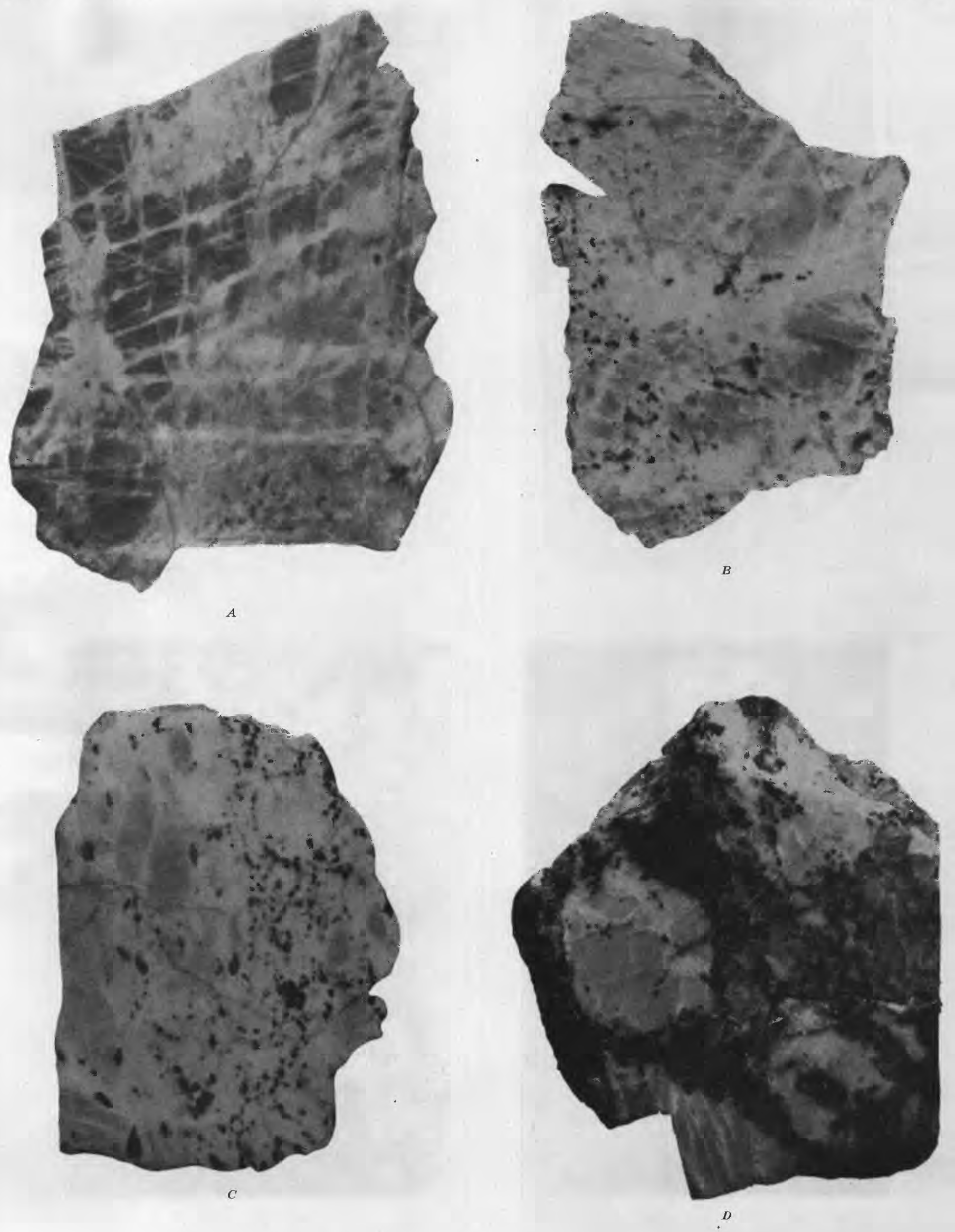


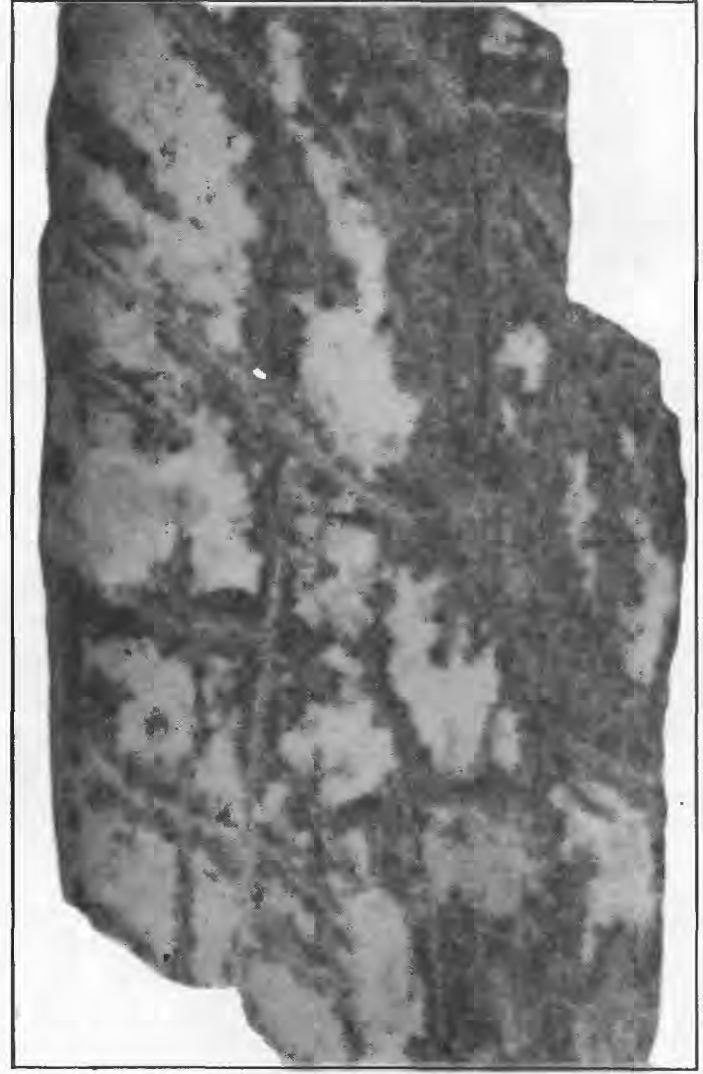

A

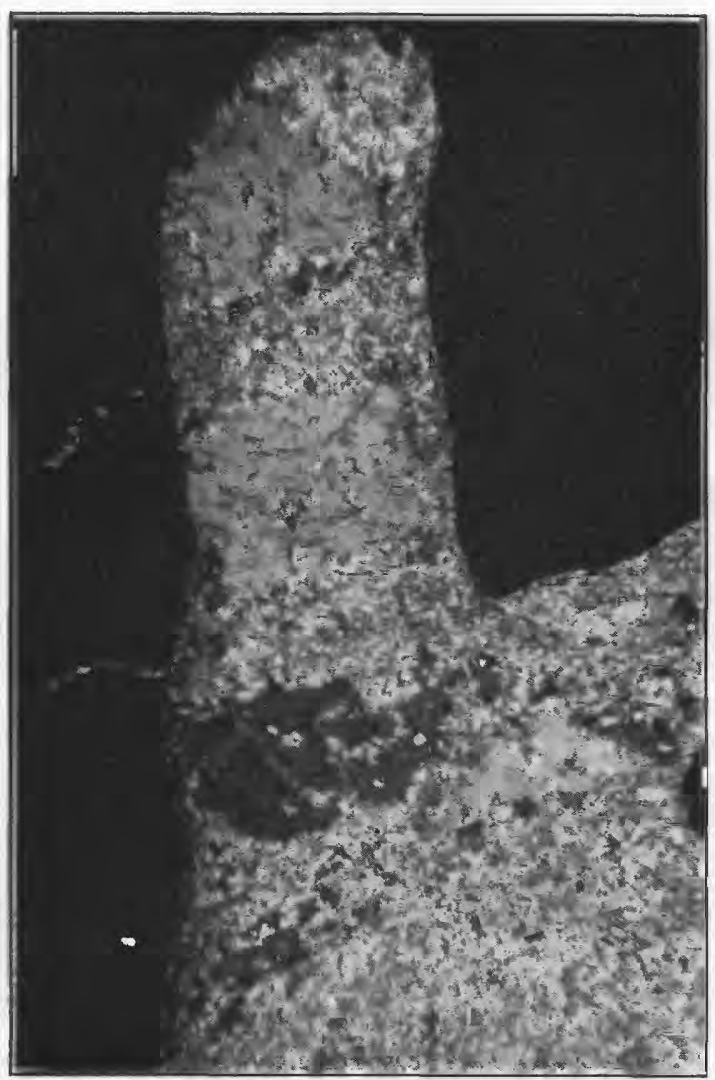

C

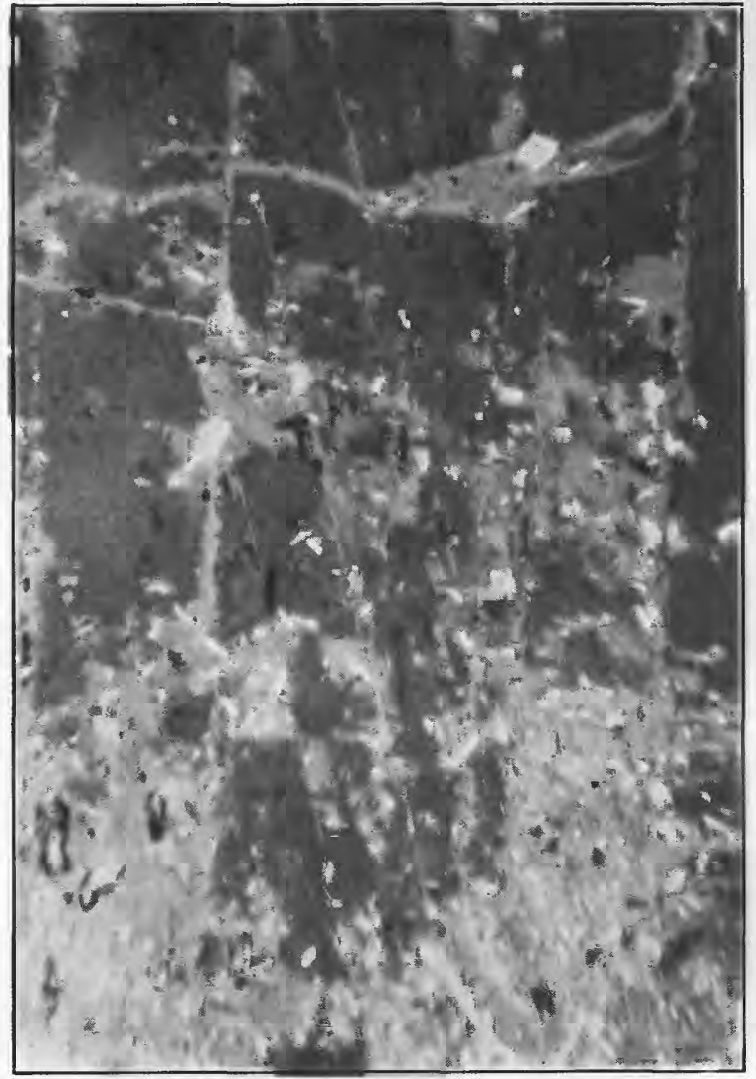

B

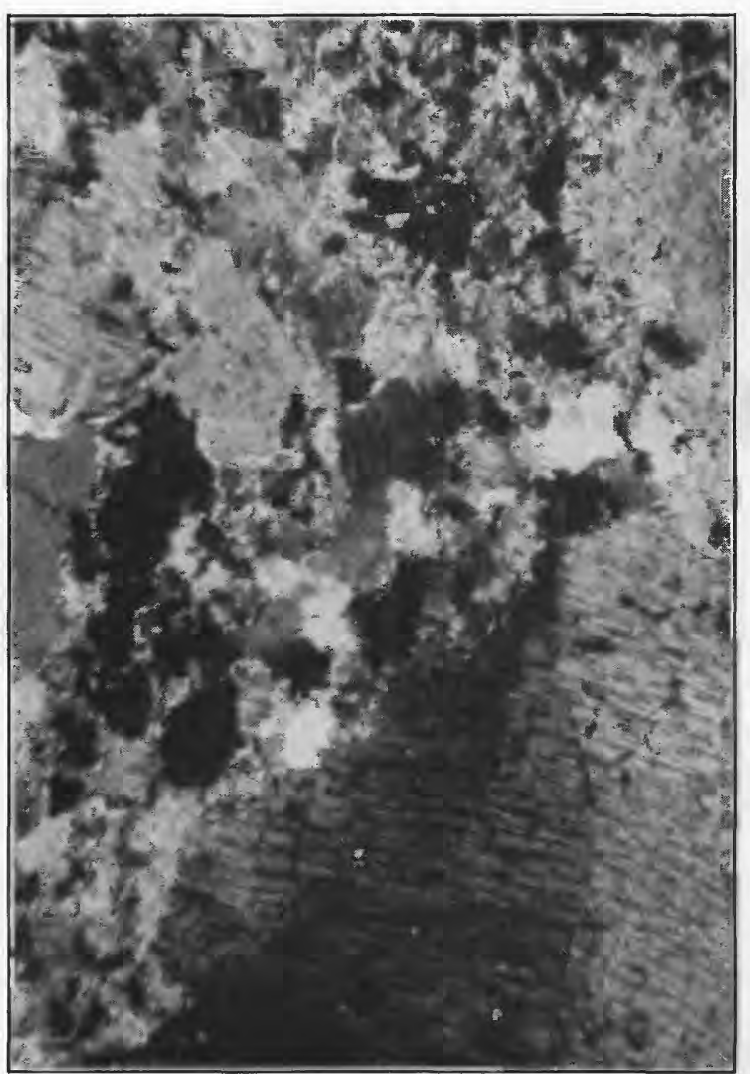

D 


\section{PLATE 2}

\section{REPLACEMENT OF FELDSPAR BY SECONDARY MINERALS}

A. Photograph of a polished specimen from mine of Dominion Minerals, Inc., on Piney River about a mile northwest of the Charlottesville-Lynchburg road. Finely granulated feldspar has been cut by a series of fractures, along which secondary minerals have formed. These are clinozoisite, sericitic muscovite, and tremolite. Natural size.

B. Photomicrograph of a thin section of feldspar from the mine of the American Rutile Co., cut from the specimen shown on plate 1, A. The upper part shows nearly fresh primary feldspar cut by shear zones, along which granulation has occurred. In the lower part, where granulation has been nearly complete, secondary silicates (sericitic muscovite and clinozoisite) have formed; they show as small white grains, which are nearly absent in the primary feldspar. Crossed nicols. $X 48$.

C. Photomicrograph of a thin section of a specimen from the mine of the American Rutile Co. Two residual areas of single feldspar crystals contain disseminated grains of secondary silicates. The granular parts represent nearly complete replacement of feldspar by tremolite, clinozoisite, and sericitic muscovite. Black enclosing material is ilmenite. $\times 48$.

D. Photomicrograph of a thin section of anorthosite from the mine of the American Rutile Co. The lower right part represents a strained but ungranulated area of antiperthitic feldspar. The remainder represents granulated feldspar and shows the great variation in the size of grain. These grains retain the antiperthitic structure of the primary feldspar. Near the top are abundant grains of secondary silicates, which are almost absent in the ungranulated material. Crossed nicols. $X 48$. 


\section{PLATE 3}

\section{PHOTOMICROGRAPHS OF FELDSPATHIC ROCKS SHOWING REPLACEMENT BY SECONDARY MINERALS}

A. Specimen from the mine of the American Rutile Co. The lighter part is andesine and the darker irregular veinlets are clinozoisite. $\times 28$.

B. Part of a single crystal of antiperthitic andesine from the mine of the American Rutile Co. The dark material-is ilmenite, which has formed most abundantly along shear zones. $\times 48$.

$C$. Ungranulated feldspar from the mine of the American Rutile Co., similar to the material illustrated on plate 1, $A$. The small discontinuous lenses are microcline enclosed in andesine. Dark areas are secondary silicates. $X 86$.

D. Specimen from a small aplitic dike at the Massies Mill School. Minute lenses of albite are enclosed in microcline. The mutual relations of the two feldspars are the reverse of those shown on $C$. Near the lower left corner are two small grains of quartz, and just above this is a small veinlet of quartz that follows a cleavage plane in the feldspar. $\times 36$. 
GEOLOGICAL SURVEY

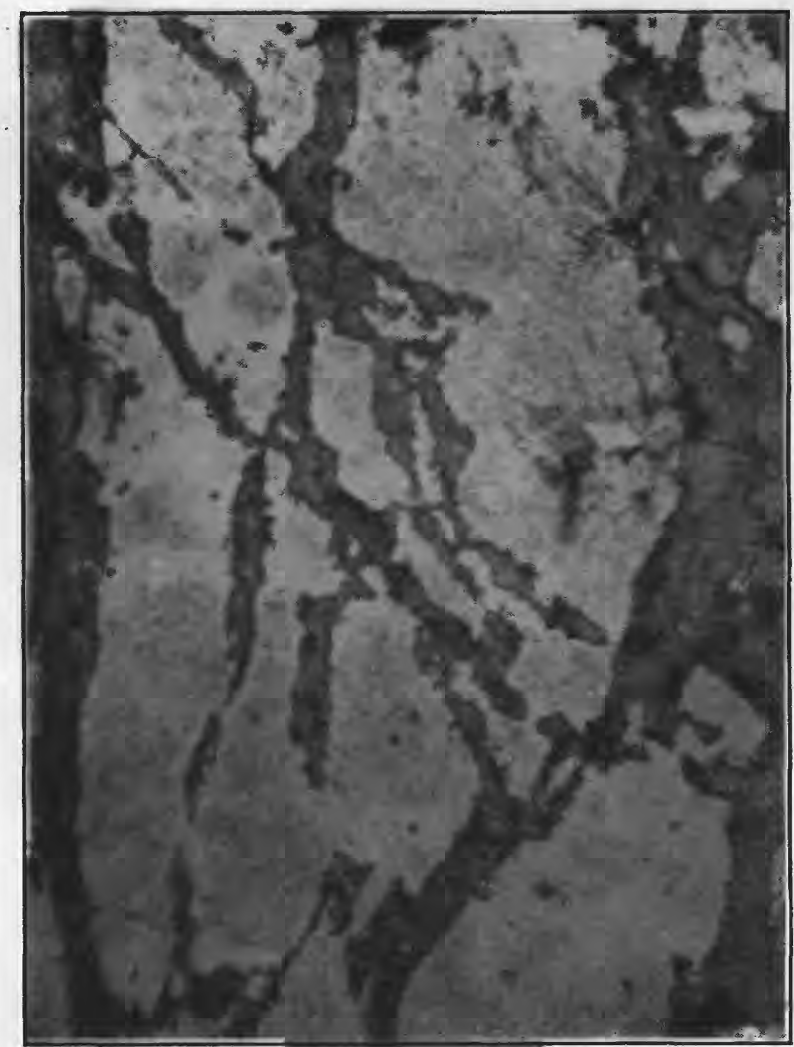

A

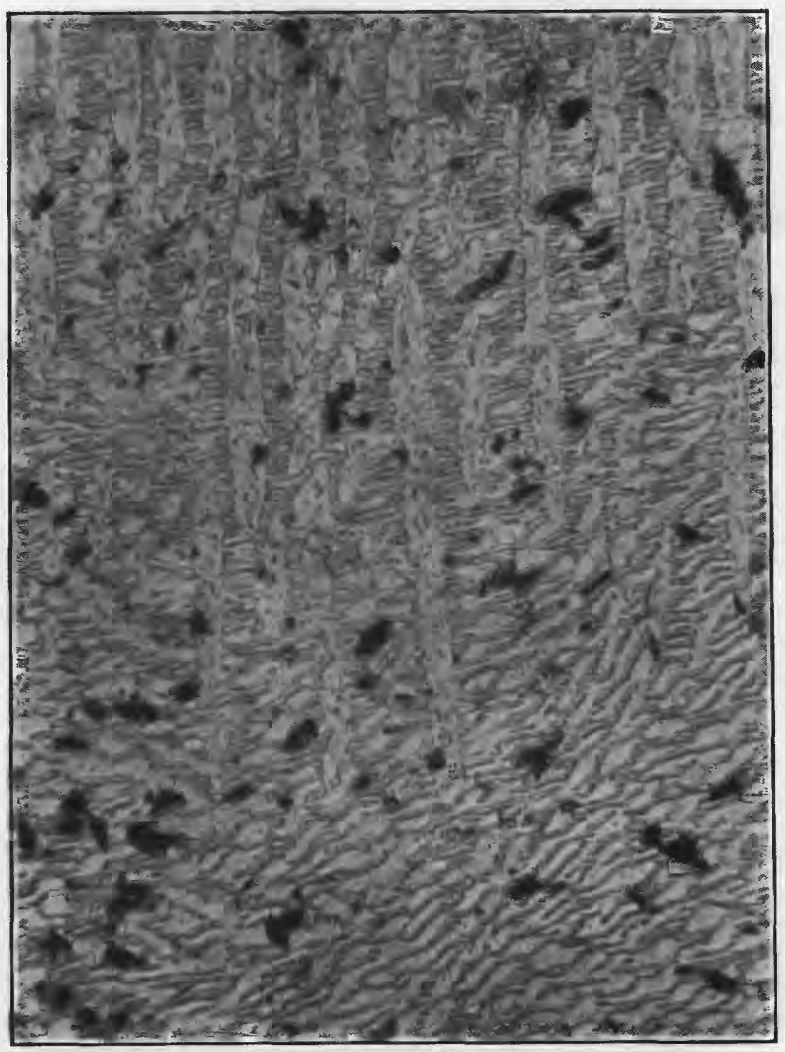

C
PROFESSIONAL PAPER 198

PLATE 3

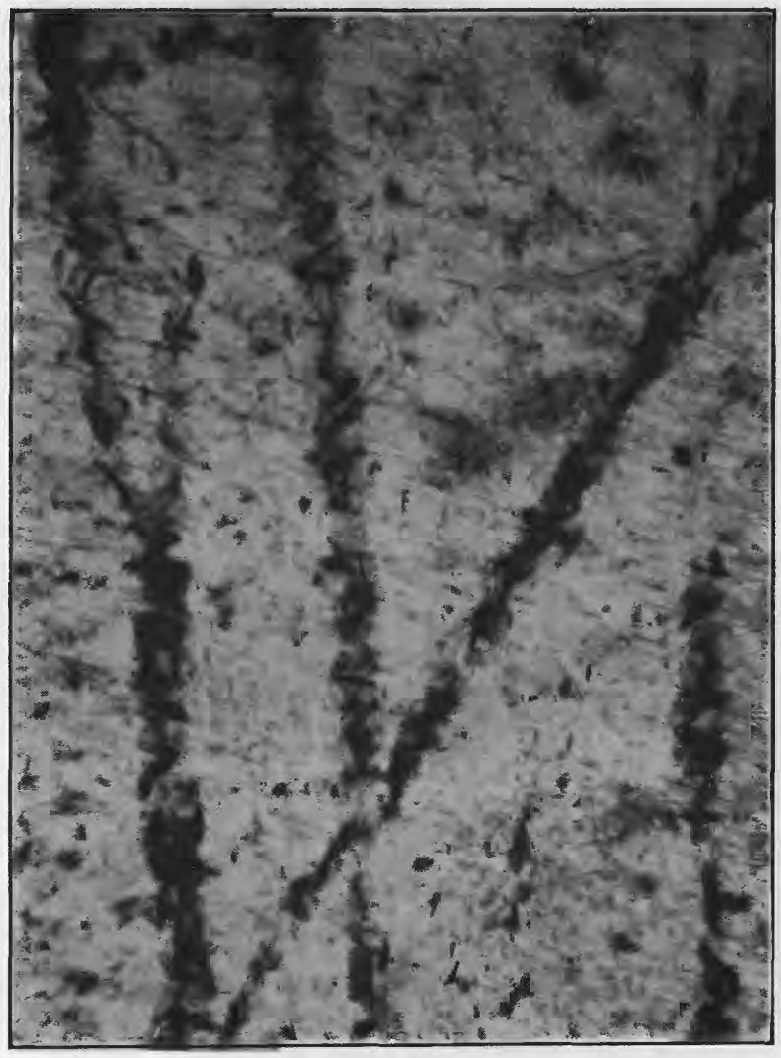

B

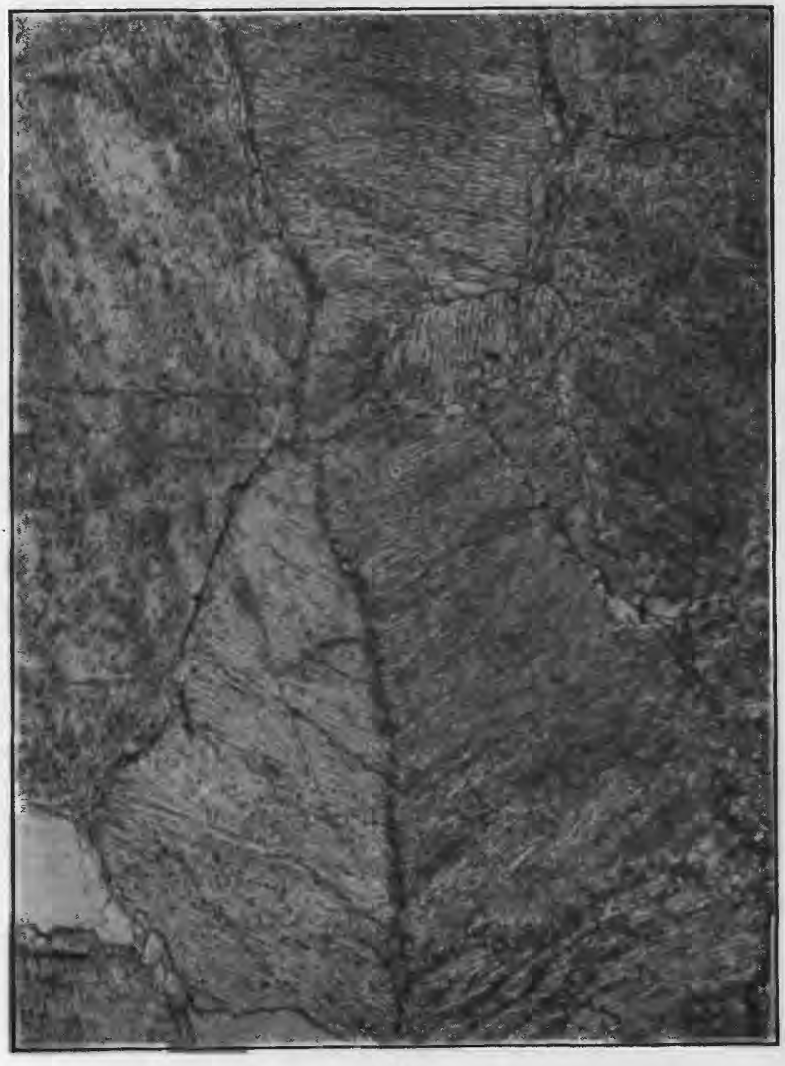

D 


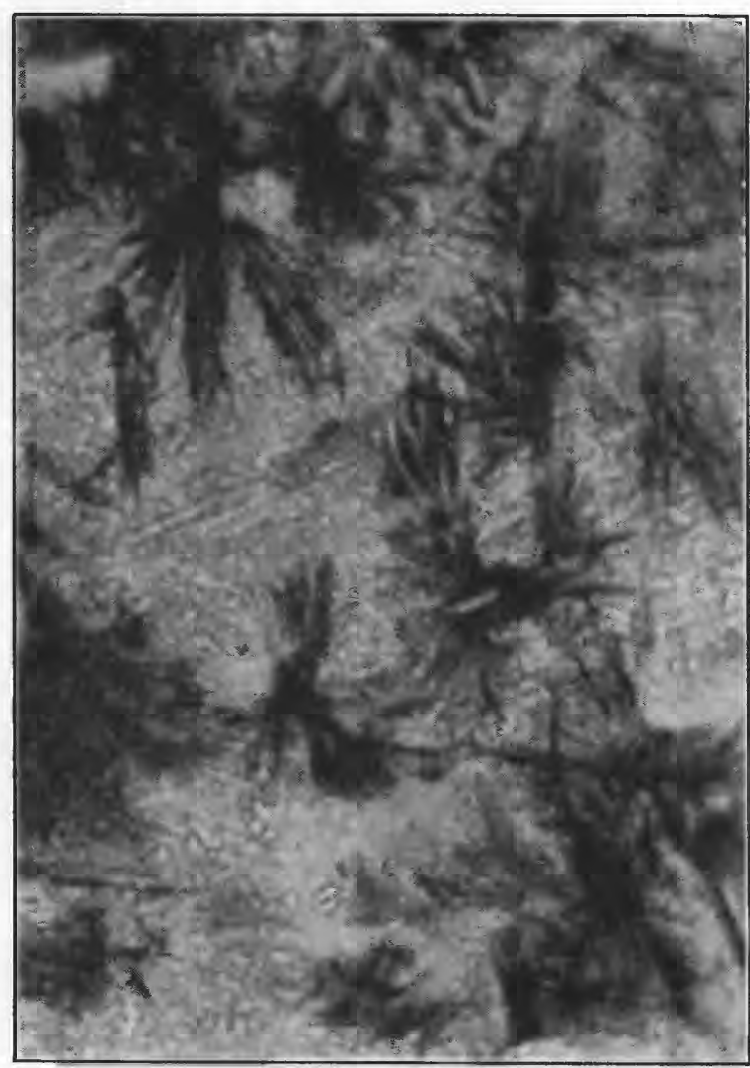

$A$

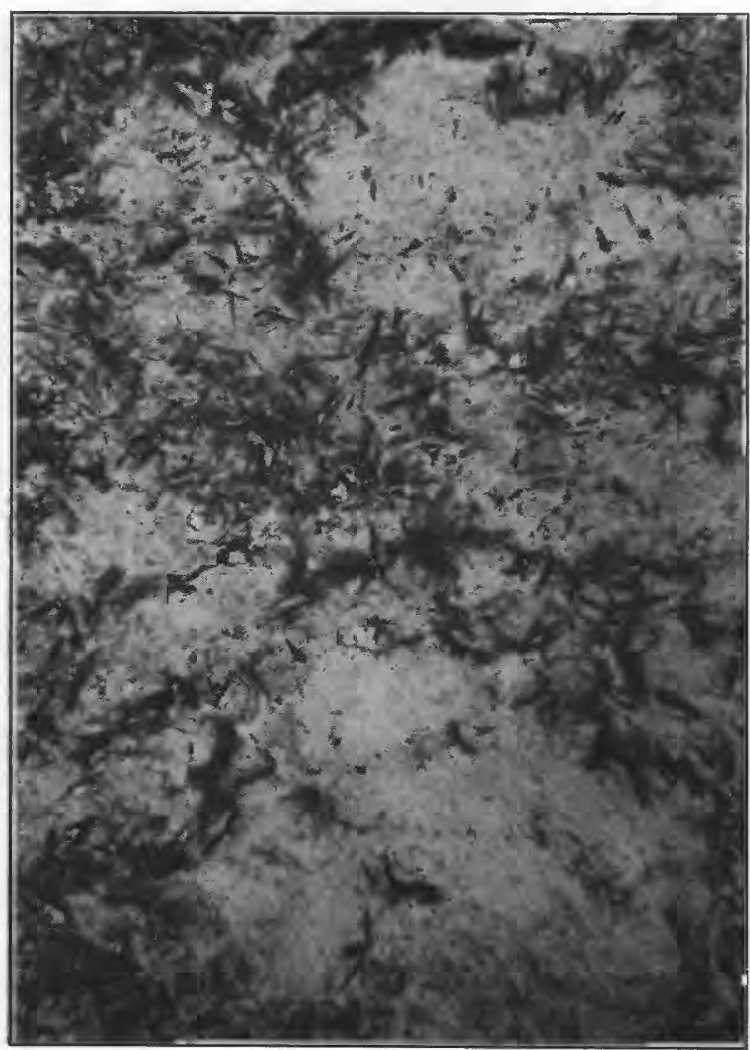

C

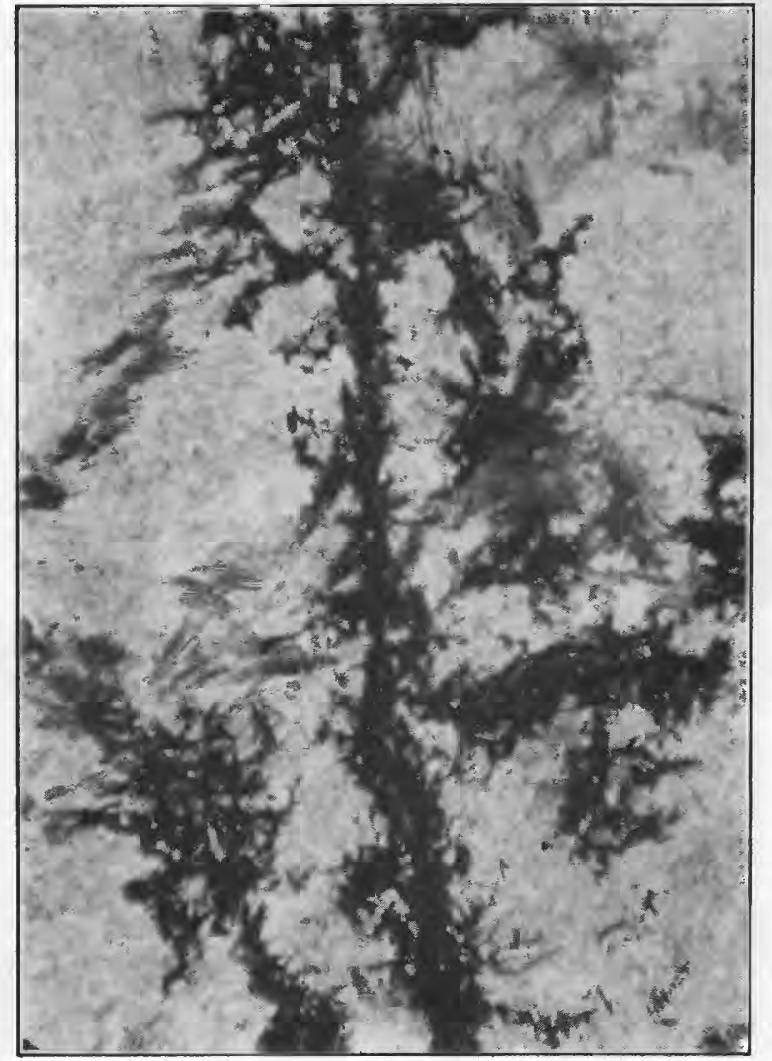

B

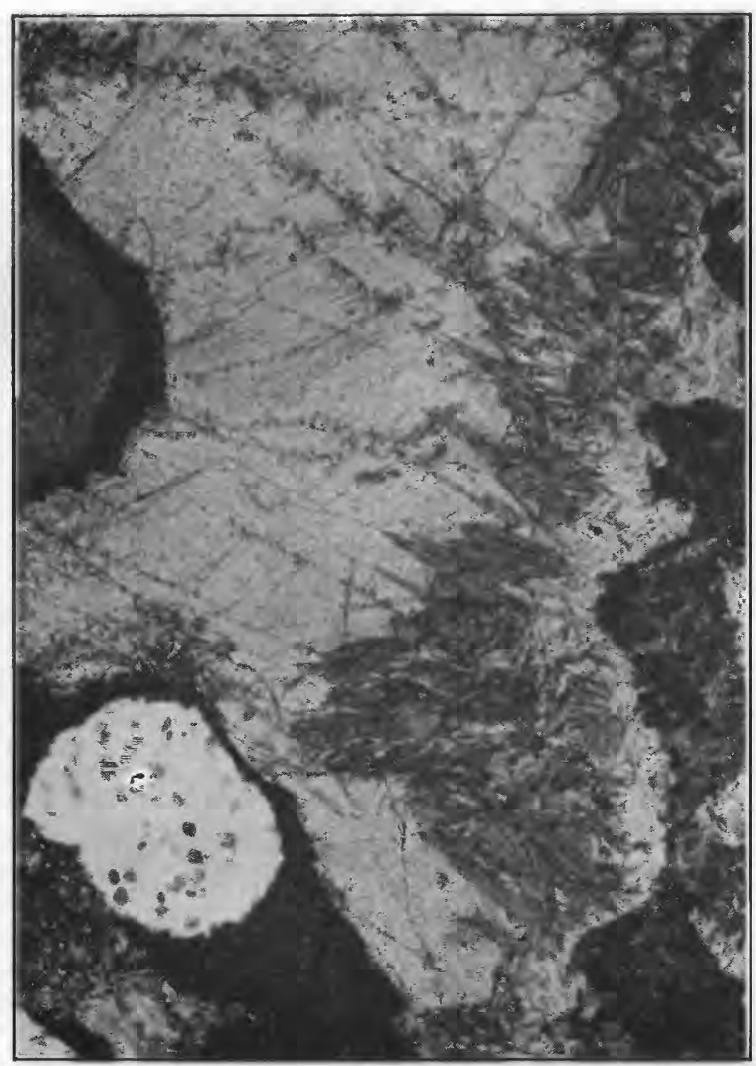

D 


\section{PLATE 4}

\section{PHOTOMICROGRAPHS OF THIN SECTIONS SHOWING REPLACEMENT OF FELDSPAR BY SECONDARY MINERALS}

A. Altered anorthosite from the mine of the American Rutile Co. The sheaflike groups of erystals are clinozoisite. Light-colored mottled material in the groundmass is tremolite and sericitic muscovite. A trace of the original antiperthitic structure of the feldspar shows as faint diagonal lines. $\times 86$.

B. Altered anorthosite from the mine of Dominion Minerals, Inc., on Piney River 1 mile northwest of the Charlottesville-Lynchburg road. Black areas are pyrite of dendritic habit. Dark-gray areas are clinozoisite. The light-gray mottled material is white feldspar enclosing sericitic muscovite and tremolite. $\times 48$.

C. Altered anorthosite from the mine of the American Rutile Co. Black areas are clinozoisite. Near the lower part is an area of badly corroded antiperthitic feldspar. $\times 48$.

D. Material from a small lens in the nelsonite mine of the Southern Mineral Products Corporation. The light-colored central area is andesine, which has been replaced by hornblende along its right border. The dark grain near the upper left corner is a very fine grained aggregate of hornblende, which has completely replaced augite. The dark border is a reaction rim of finegrained clinozoisite. The white area in the lower left corner is the result of the breaking away of the fine-grained hornblende. $\times 36$. 


\section{PLATE 5}

\section{PHOTOMICROGRAPHS OF THIN SECTIONS SHOWING REPLACEMENT}

A. Blue-gray rutilated quartz from the mine of the American Rutile Co. The section is cut perpendicular to the optical axis of the quartz. Note the large proportion of rutile needles that make an angle of $60^{\circ}$ with one another. This distribution is symmetrical around the $c$ axis of the quartz and evidently has been controlled by the trigonal symmetry of the quartz. The rutile needles are 0.3 to 0.5 microns in diameter, and some reach several millimeters in length. $\times 86$.

$B$. Specimen from the mine of the American Rutile Co., which shows quartz (white areas) partly replaced by actinolite. Needles of actinolite extend into both areas of quartz. $\times 48$

C. Specimen from the mine of Dominion Minerals, Inc., on Piney River, about a mile northwest of the Charlottesville-Lynchburg road. Shows extensive replacement of anorthosite along a shear zone. The white area is quartz, the light-gray granular material is garnet and clinozoisite, and the black is pyrite. $\times 48$.

D. Specimen from the mine of the Southern Mineral Products Corporation. Rutile has formed in anorthosite, and tonguelike areas seem to have extended out along nearly parallel fracture zones that are inclined about $45^{\circ}$. $\times 24$. 

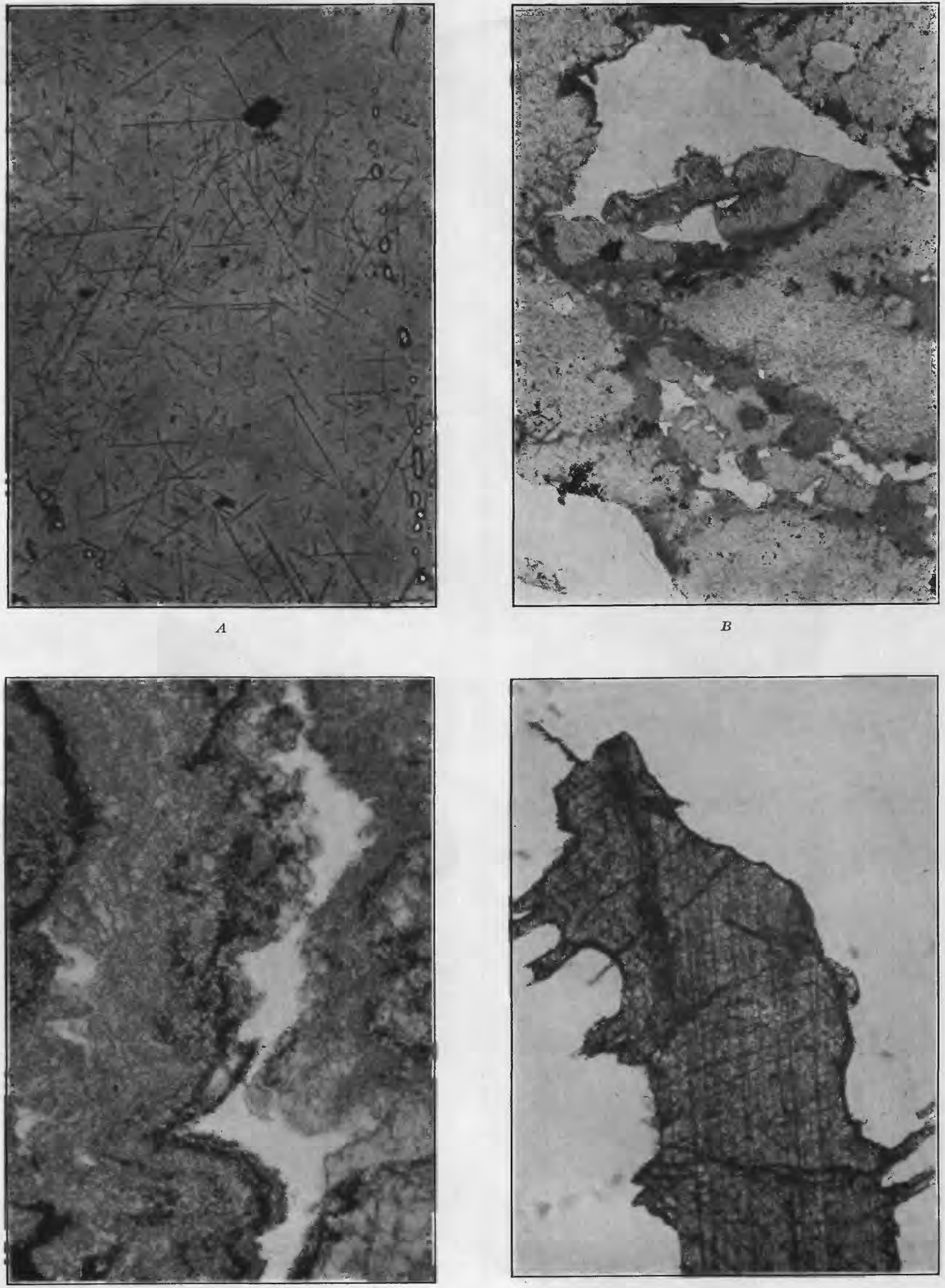


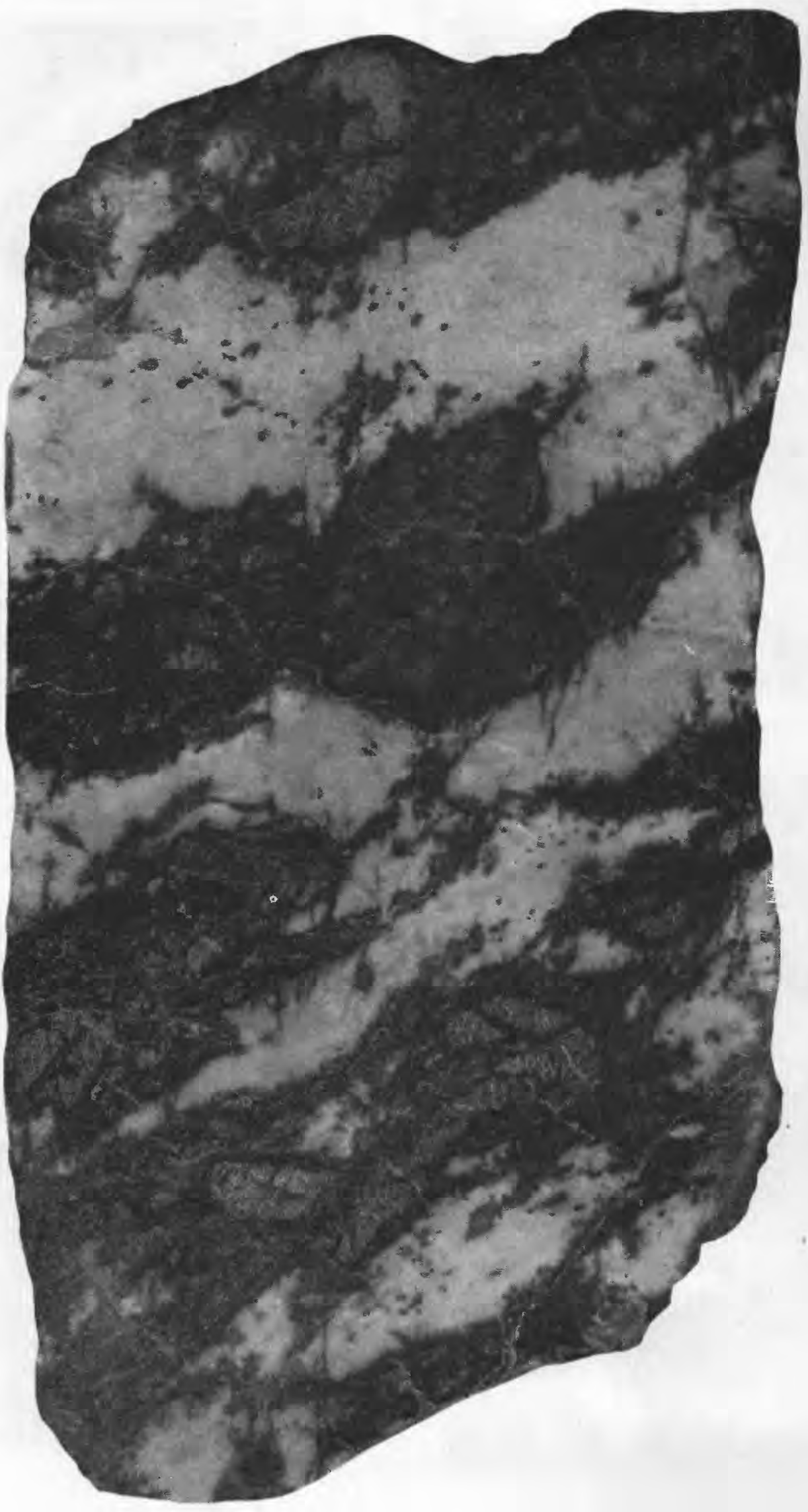




\section{PLATE 6}

PHOTOGRAPH OF A POLISHED SPECIMEN FROM THE MINE OF THE AMERICAN RUTILE CO.

Shows replacement of anorthosite along a series of parallel fractures, forming a series of lenses. The dark-gray areas are clinohypersthene; the black is hornblende, an alteration product of the clinohypersthene. Rounded dark areas in feldspar (white) are ilmenite, but most of the ilmenite occurs in the dark-colored lenses where it does not show. A second, nearly vertical system of fractures makes angles of about $45^{\circ}$ with the major fractures. The secondary fractures contain the alteration products of clinohypersthene near intersections, but for the most part they are filled with biotite. Natural size. 


\section{PLATE 7}

\section{A POLISHED SPECIMEN FROM THE MINE OF THE AMERICAN RUTILE CO.}

Shows replacement of anorthosite localized along shear planes. The dark areas are clinohypersthene and its alteration product hornblende. A secondary set of fractures makes angles of about $45^{\circ}$ with the major fractures. Along these secondary fractures secondary silicates, largely biotite, have also formed. Dark, rounded areas are ilmenite. Natural size. 


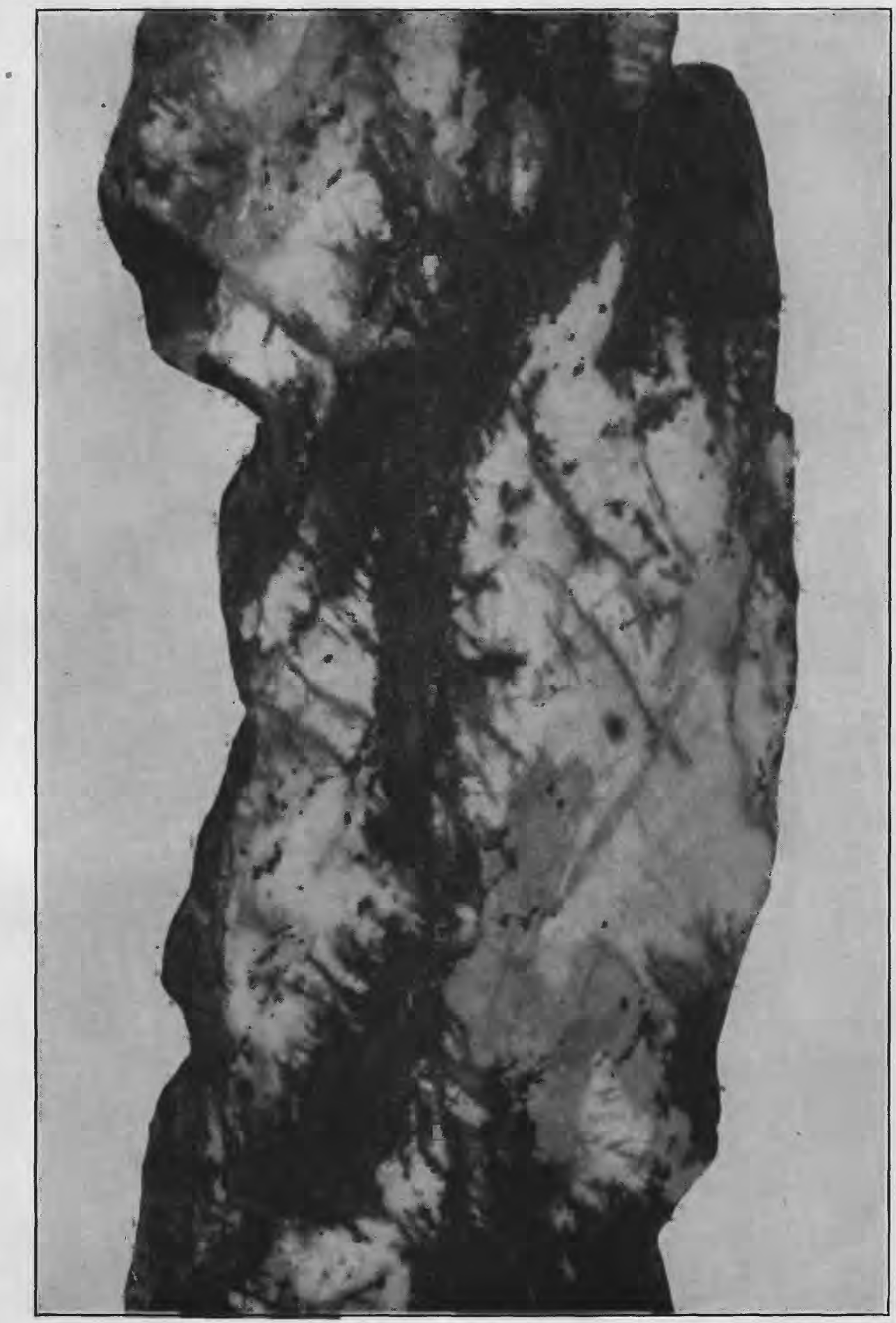




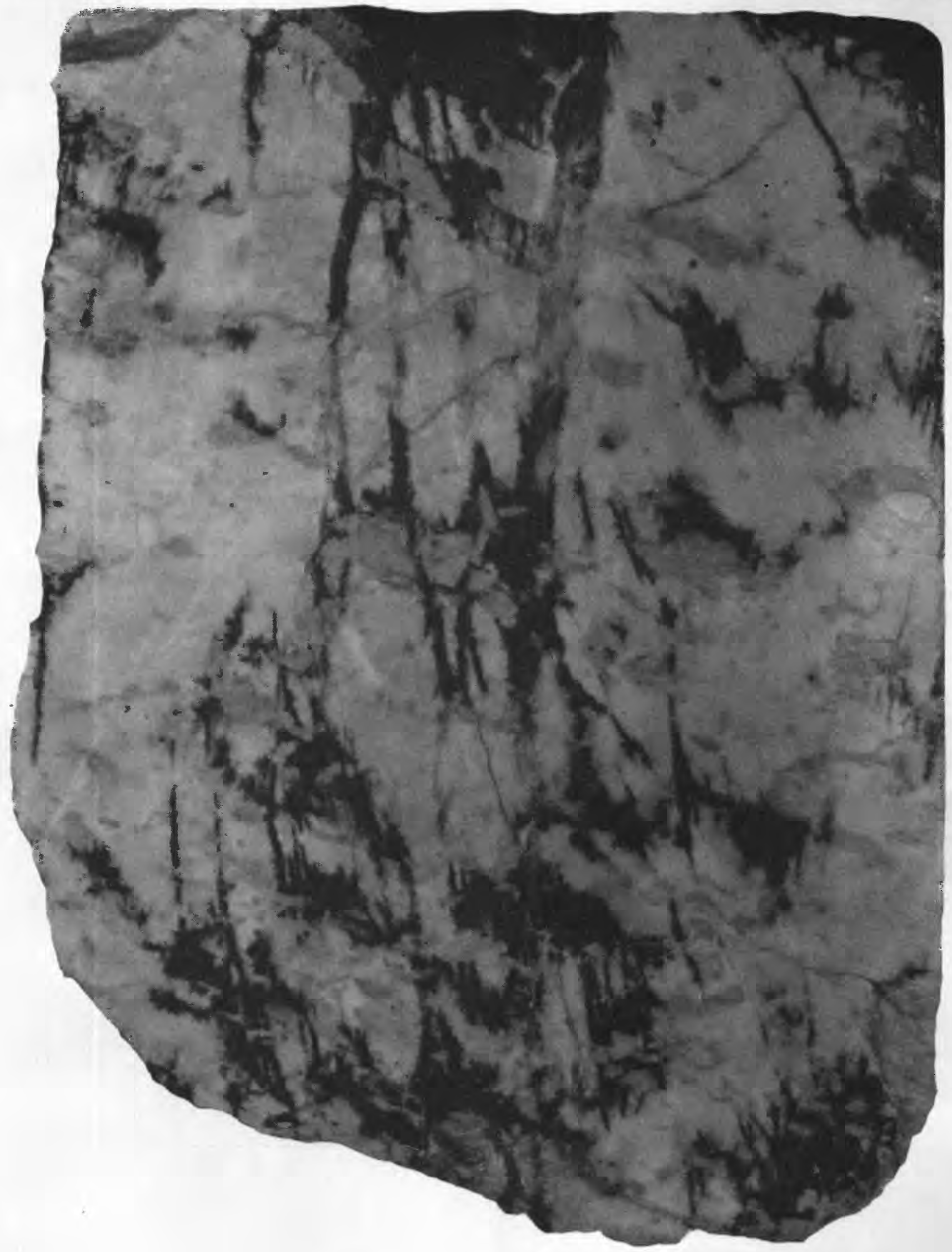




\section{PLATE 8}

PHOTOGRAPH OF A POLISHED SPECIMEN FROM THE MINE OF THE AMERICAN RUTILE CO.

Hornblende has replaced anorthosite along a system of parallel fractures. Numerous areas of blue-gray quartz are distributed throughout the specimen and are of a slightly darker gray than the feldspar. Some of these form distinct veins, but others are irregular or rounded masses. In many places the earlier quartz veins have been replaced by hornblende. Shear zones cut quartz as well as feldspar, and both contain hornblende. Thus the sequence of mineralization is feldspar, quartz, hornblende. Natural size. 
PLATE 9

TWO POLISHED SPECIMENS FROM THE MINE OF THE AMERICAN RUTILE CO. SHOWING REPLACEMENT Natural size

A. Large partly replaced crystal of clinohypersthene. Granular light-gray areas are apatite, white area at the top is quartz. Just to the left of the center and between the two apatite areas is a large grain of ilmenite. The clinohypersthene has been partly replaced along the cleavage planes, which are nearly horizontal, by hornblende and ilmenite.

B. The dark-gray area is composed of clinohypersthene that has been partly replaced by hornblende (black). Ilmenite (not visible) has formed within the hornblende veins. Two areas of pyrrhotite $(P)$ occur near the lower margin. Veinlets of secondary minerals have formed along fractures in the feldspar.

48 


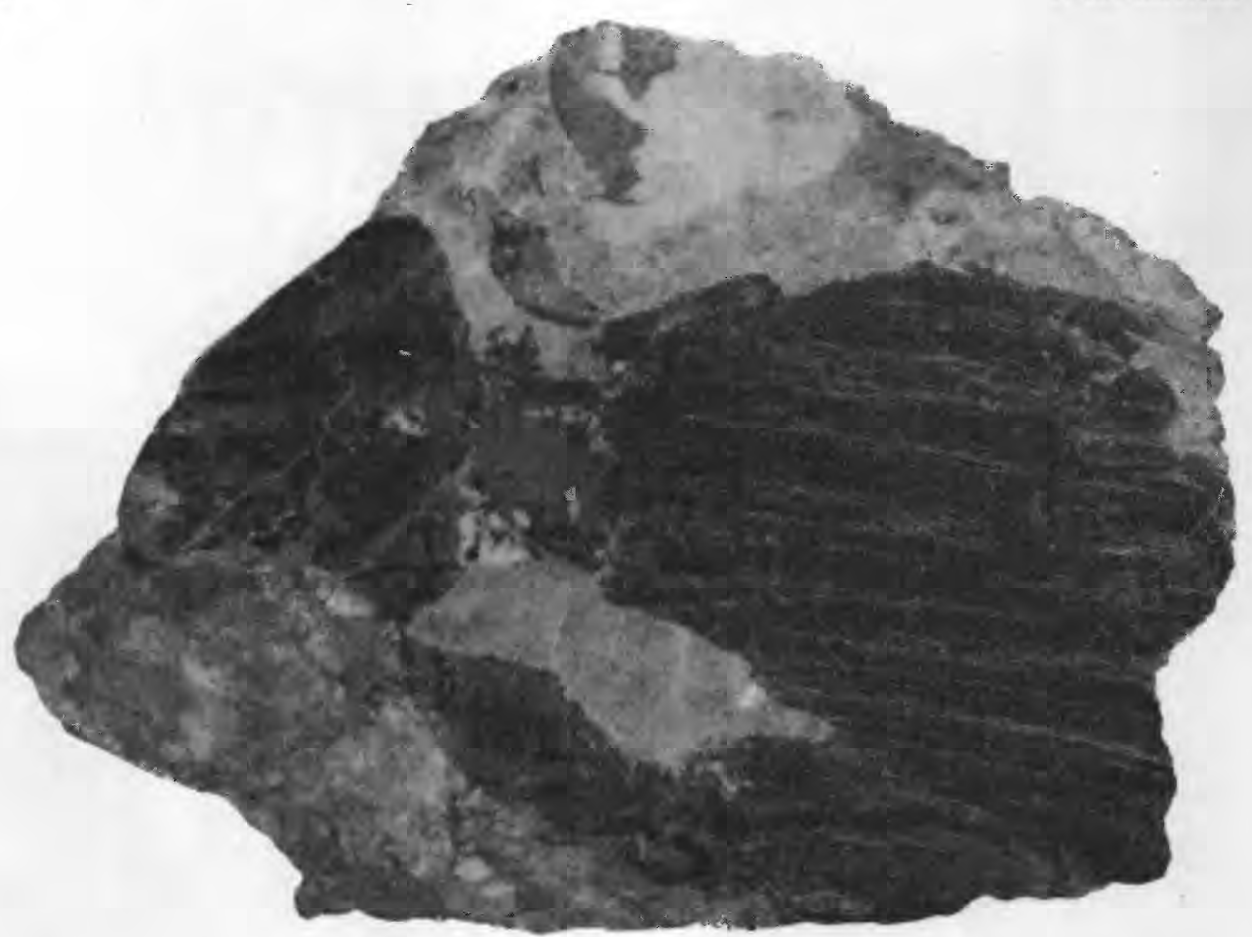

A

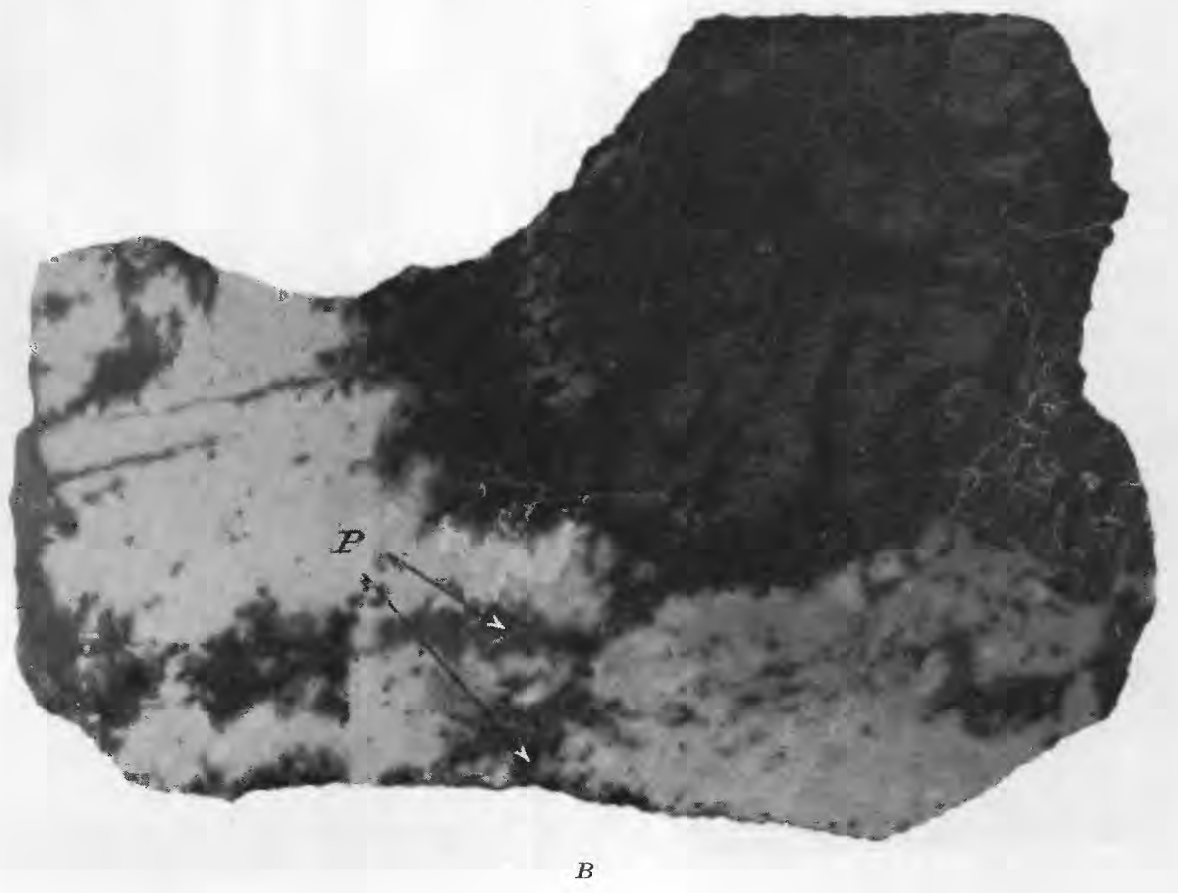




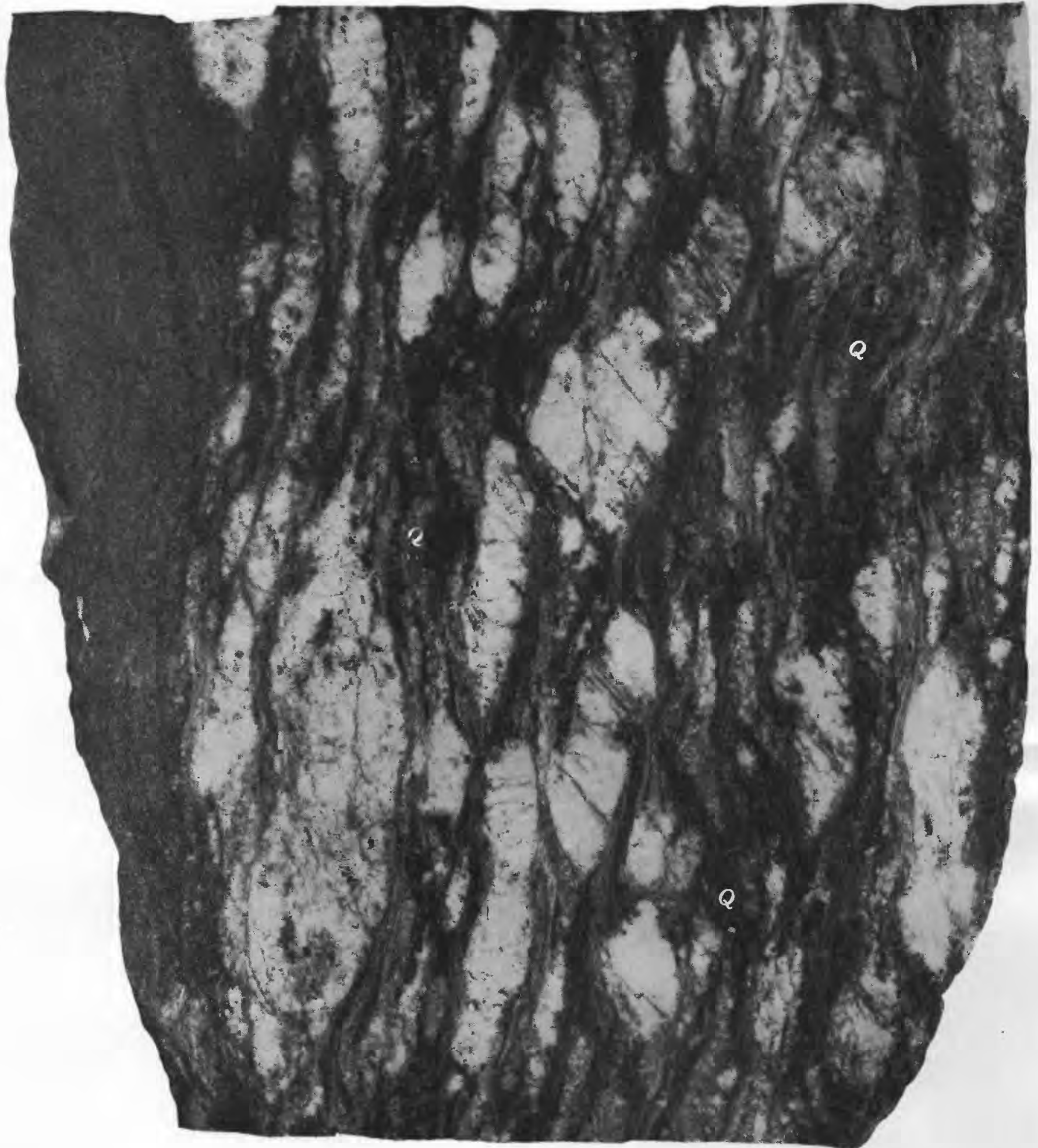


PLATE 10

\section{PHOTOGRAPH OF A POLISHED SPECIMEN OF INJECTION GNEISS}

Taken near the contact between the schistose country rock and the anorthosite, on the bank of Tye River about a mile southeast of Massies Mill. The dark-gray areas are partly mineralized and distorted schist. White areas are feldspar composed dominantly of perthitic microcline. The introduced minerals in the dark-colored schistose areas are ilmenite, dark-blue quartz $(Q)$, amphiboles, and biotite. A later system of shear zones, which consist essentially of sericitic muscovite, bend around the feldspar grains and cut diagonally across them. Black areas within feldspar are ilmenite. Natural size. 


\section{PLATE 11}

\section{PHOTOGRAPH OF A POLISHED SPECIMEN FROM THE OLD MINE OF THE GENERAL ELECTRIC CO. ON PINEY RIVER SHOWING REPLACEMENT OF ANORTHOSITE BY NELSONITE}

The left and lower parts of the specimen are anorthosite consisting of granulated feldspar $(F)$ that contains abundant minute disseminated grains of secondary silicates. The central area is similar but is completely surrounded by apatite $(A)$. At the extreme right is nelsonite $(N)$, composed of apatite and rutile. The medium-gray irregular areas or veinlets within the feldspar are largely secondary silicates, of which clinozoisite $(Z)$ is dominant. The right-hand part is granular nelsonite. The dark-gray areas at the top and to the left of the central mass of anorthosite are almost pure apatite, and apatite forms stringers that project far into the feldspar areas. Commonly the broader parts of stringers are apatite or apatite with a few rutile grains; and the narrow parts of the stringers are clinozoisite and associated secondary silicates. At the extreme right is a residual mass of anorthosite impregnated with apatite and rutile. Near the top there are gradations from apatite to feldspar rock. Natural size. 


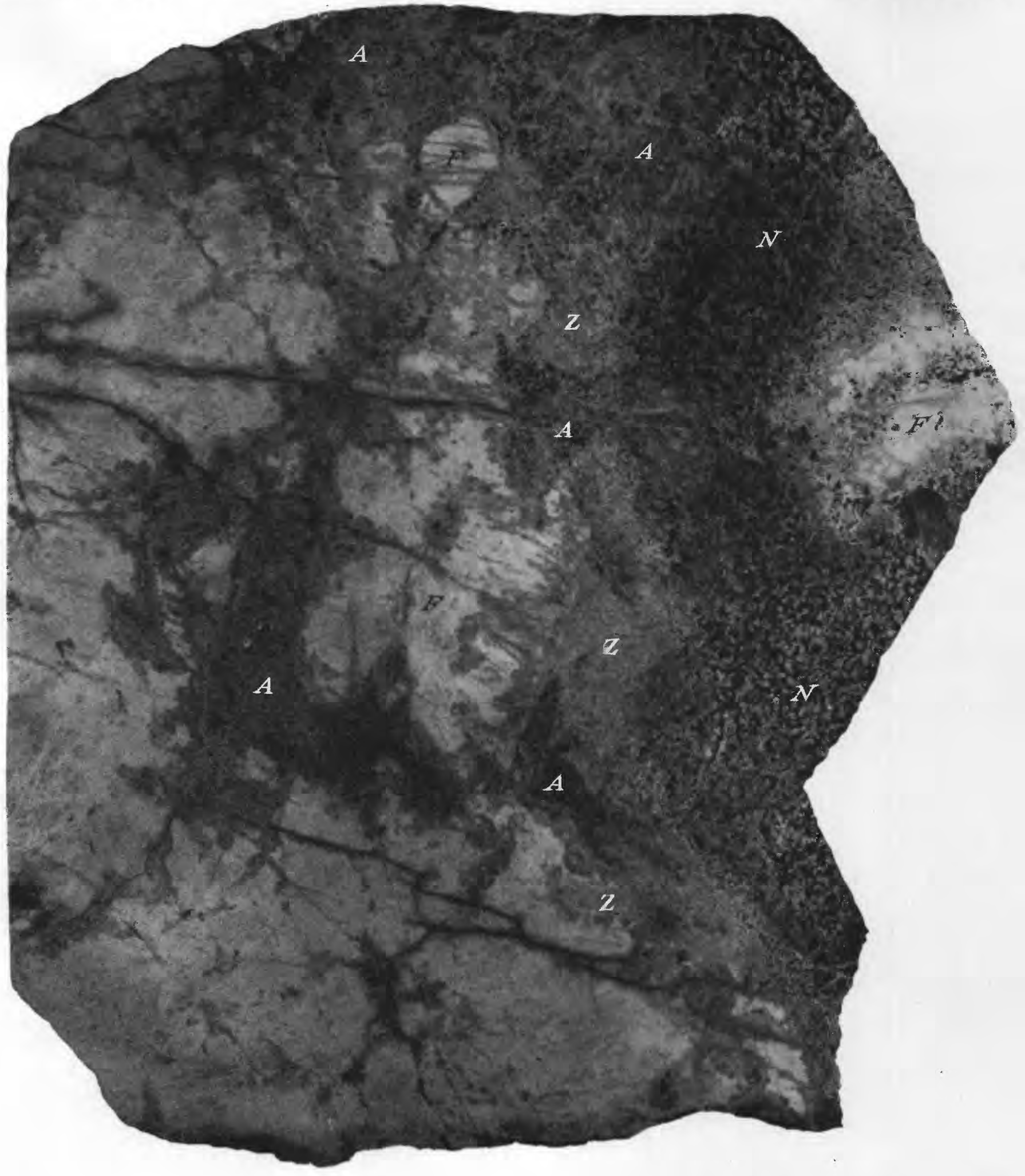



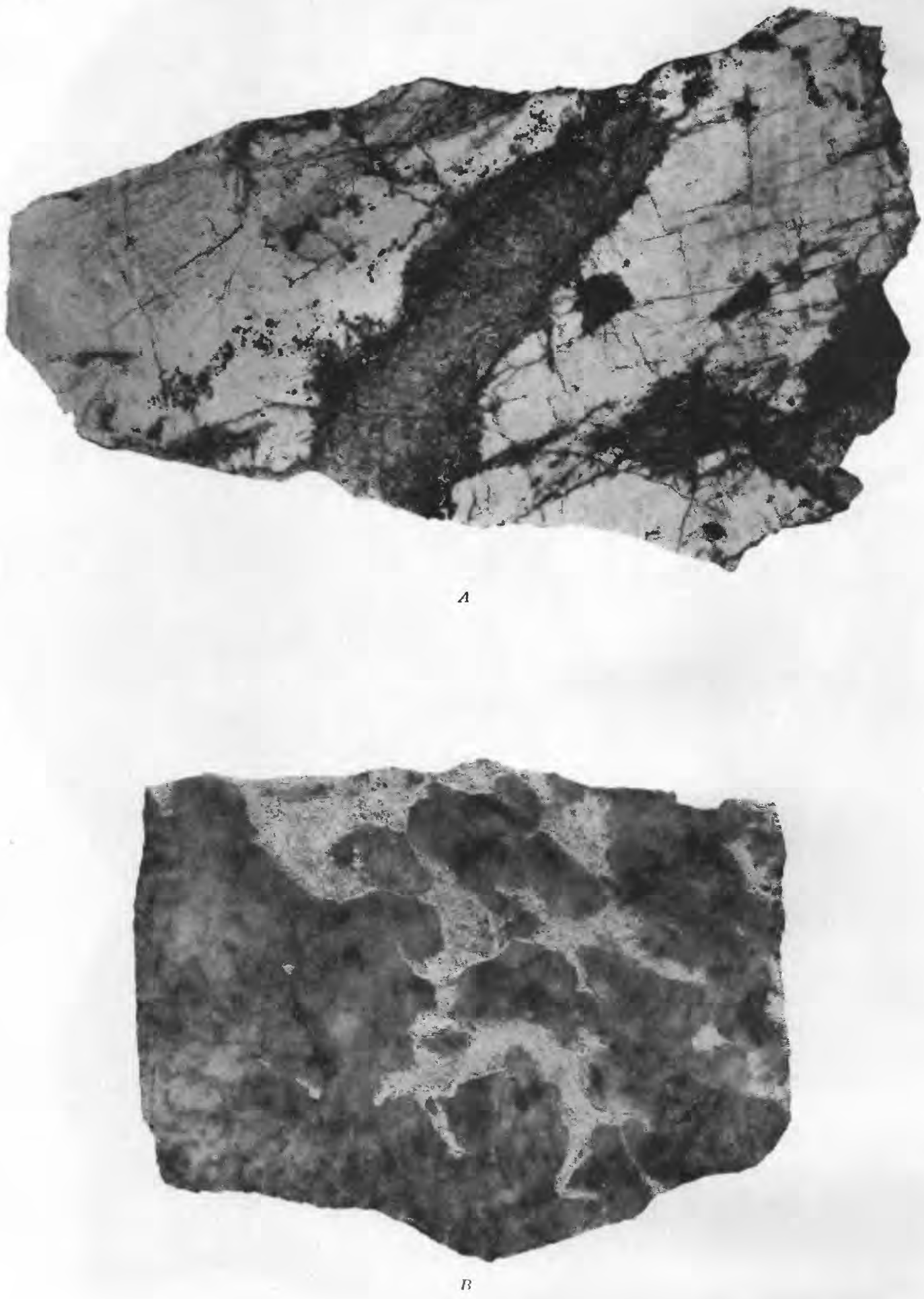


\section{PLATE 12}

\section{PHOTOGRAPHS OF POLISHED SPECIMENS SHOWING REPLACEMENT}

A. Specimen from the mine of the American Rutile Co. at Roseland. Near the center is a veinlike area of nelsonite (apatite and ilmenite) with ilmenite concentrated along the border. Numerous areas of ilmenite (black) are scattered through feldspar (white). Near the bottom ilmenite has formed along small fractures that make an angle of about $45^{\circ}$ with the large vein. Near the right and lett sides are residual areas of fractured primary feldspar enclosed in granulated material. One-half natural size.

B. Blue-gray quartz from the Bryant farm on Allen Creek with irregular areas of apatite (white). The contrast is produced by etching the apatite. Natural size. 


\section{PLATE 13}

\section{AMPHIBOLITE NELSONITE REPLACING ANORTHOSITE}

$A, B$, and $C$. Photomicrographs of amphibolite nelsonite from the Bryant farm on Allen Creek. Black areas in $A$ are elongated stringers of ilmenite that cut through the fine-grained felted aggregate of hornblende. White areas are apatite. The specimen represents a more advanced replacement of material illustrated in $C . \quad \times 48 . \quad B$ shows thick augen-shaped, residual masses of anorthosite enclosed in a fine-grained aggregate of hornblende and its alteration products. The diagonal orientation of the augen of residual feldspar was controlled by shear zones. The darker material represents zones of more intense shearing. $\quad \times 48$. The white area in $C$ is part of residual augen of feldspar similar to those shown in $B$. The granular material along the border of the feldspar augen is fine-grained colorless garnet. $\times 86$.

D. Photomicrograph of hornblende-rich nelsonite from the mine of the Southern Mineral Products Corporation. The lightcolored areas marked $a$ are apatite, and the black areas are ilmenite. The elongated augen are sheared, recrystallized, and partly replaced residual aggregates that were originally feldspar. They are surrounded by zones along which shearing has been most intense and along which nearly pure hornblende has formed. The small white area at the lower left corner is an air bubble. $\times 36$. 
GEOLOGICAL SURVEY

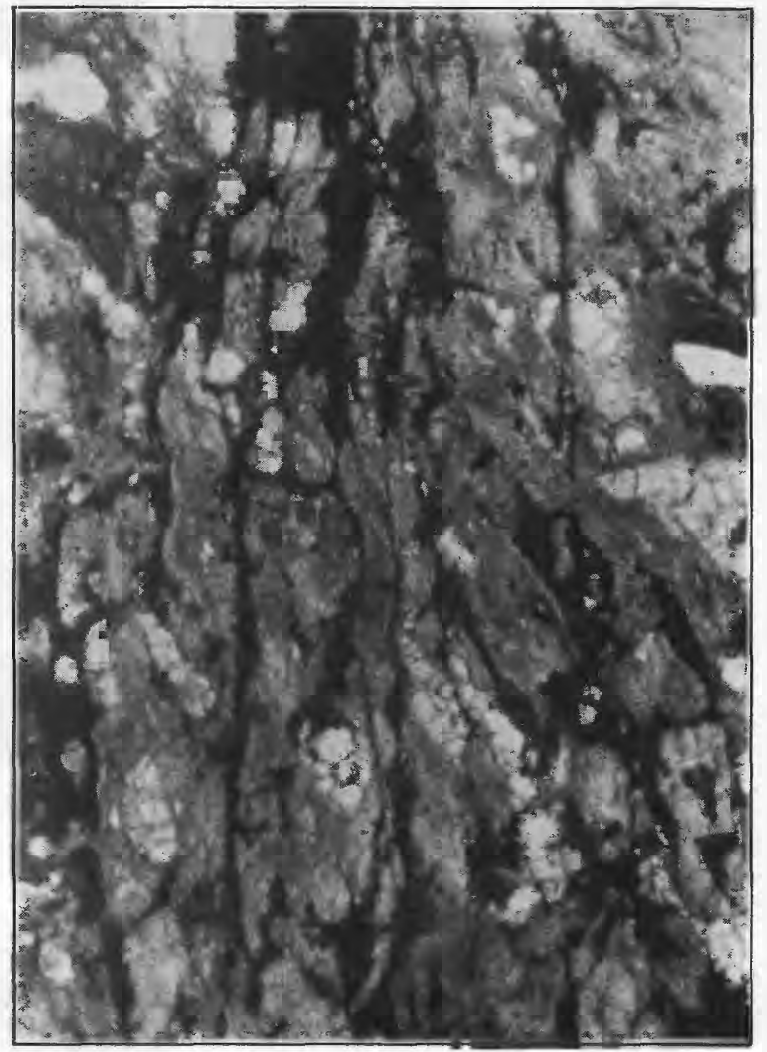

A

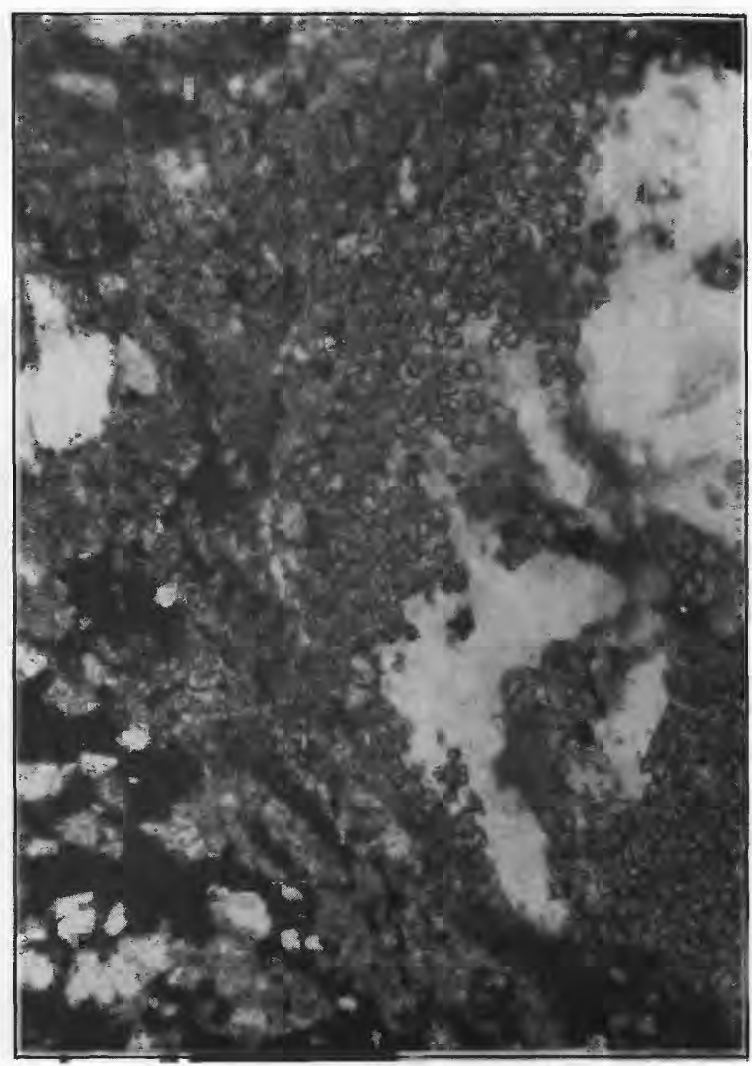

PROFESSIONAL PAPER 198 PLATE 13

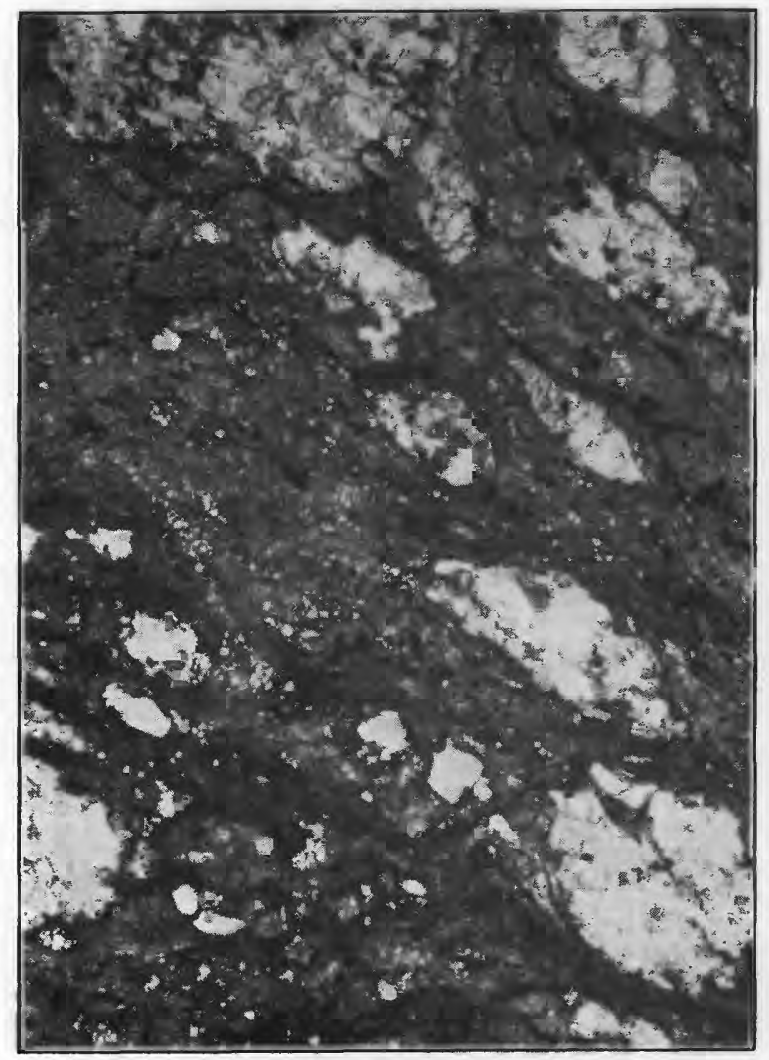

B

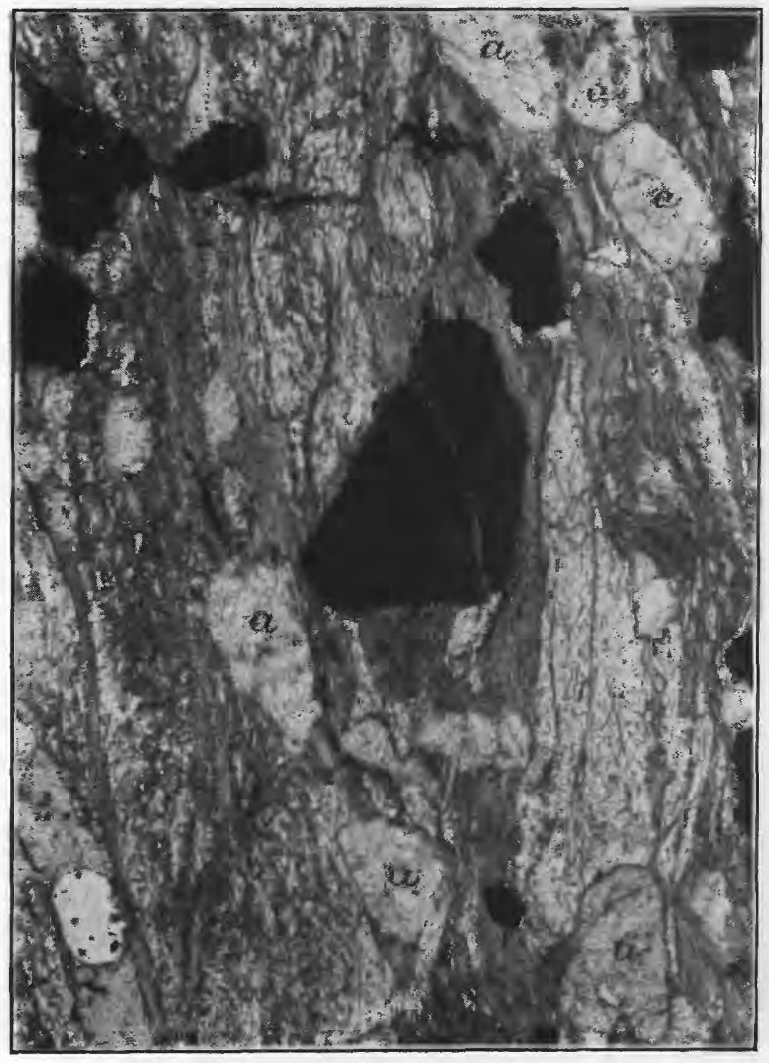

D 


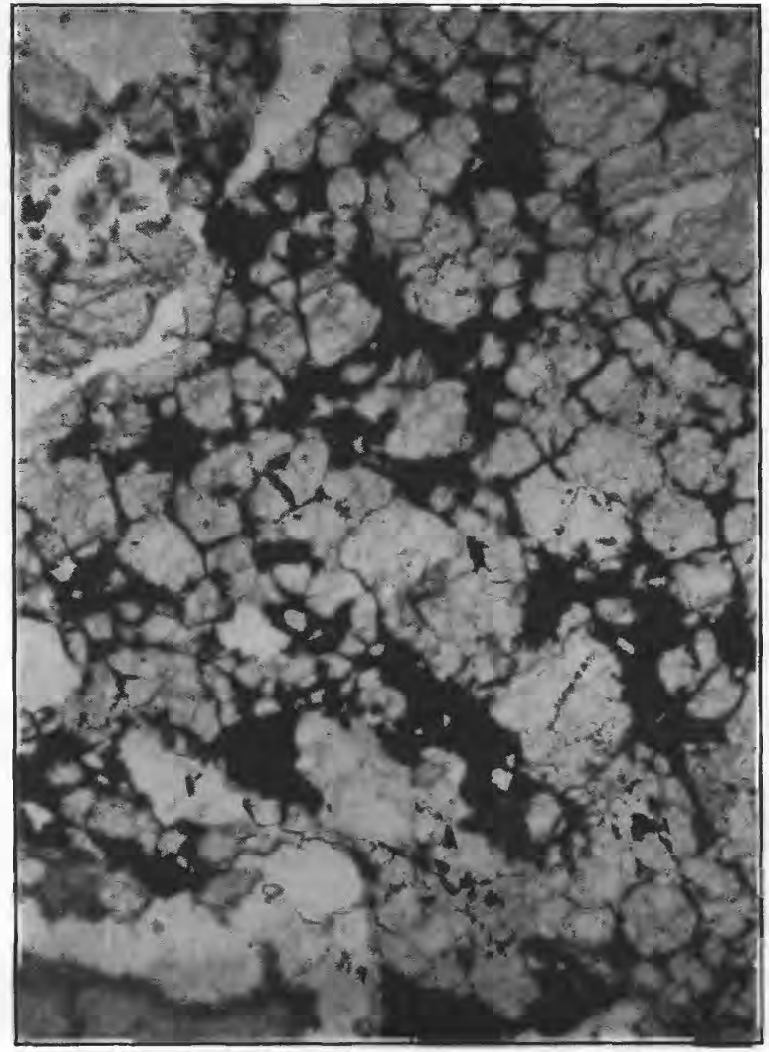

A

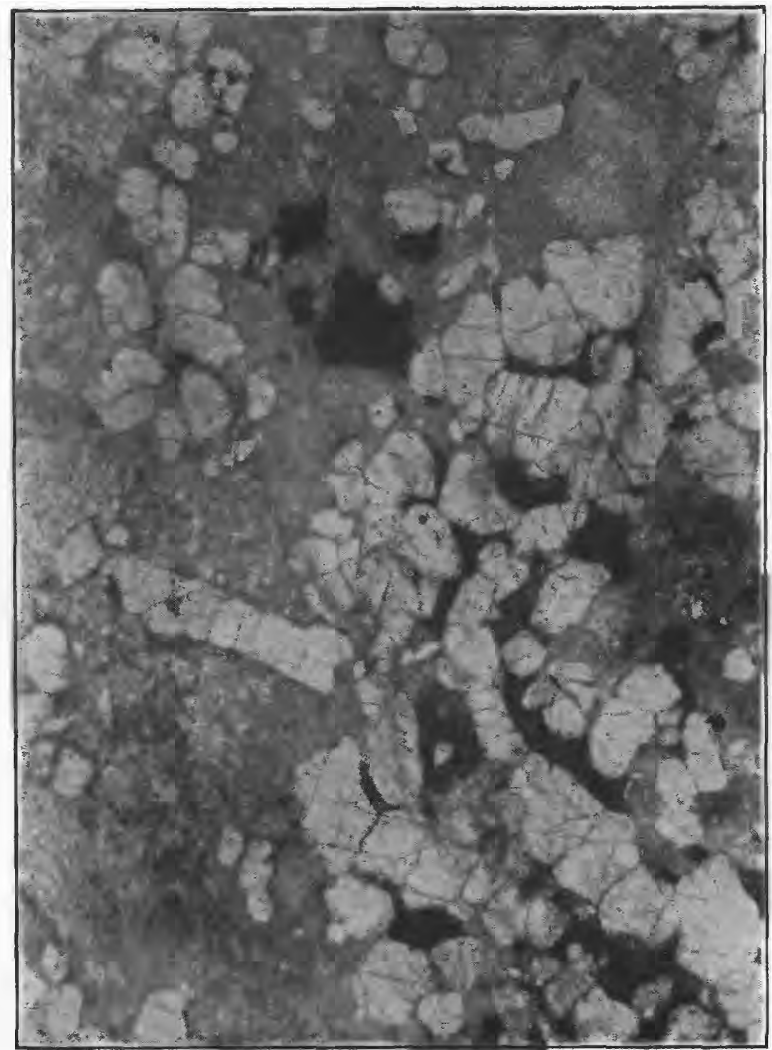

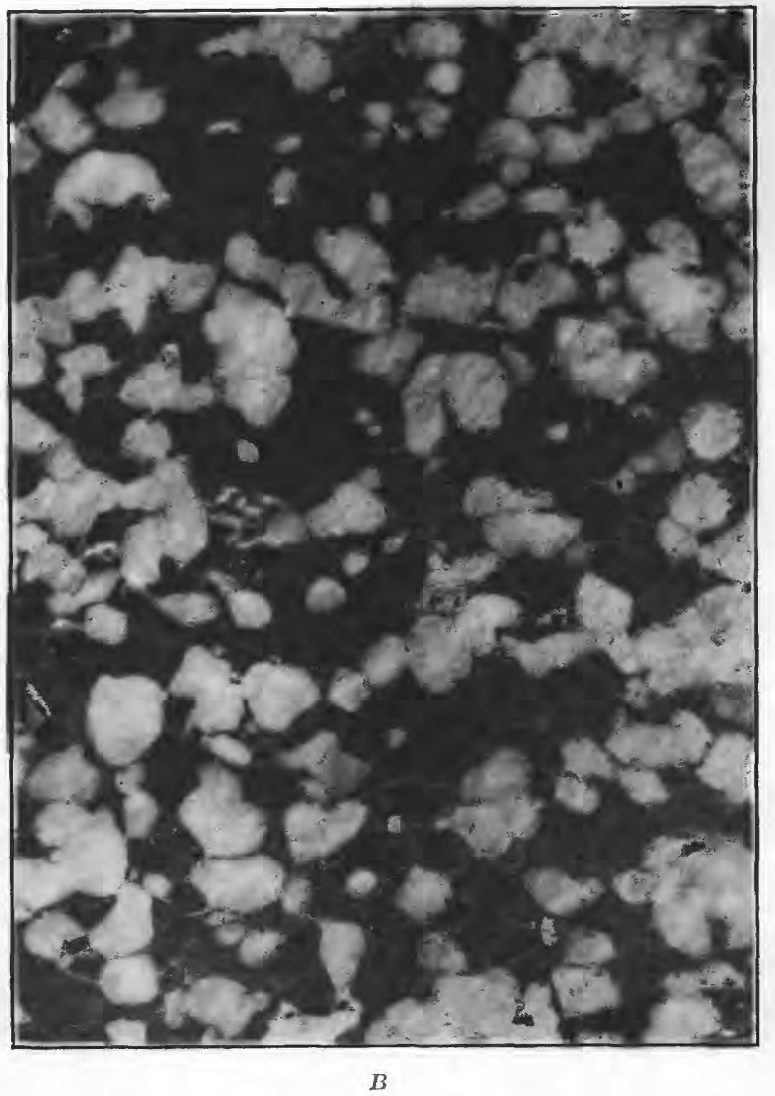

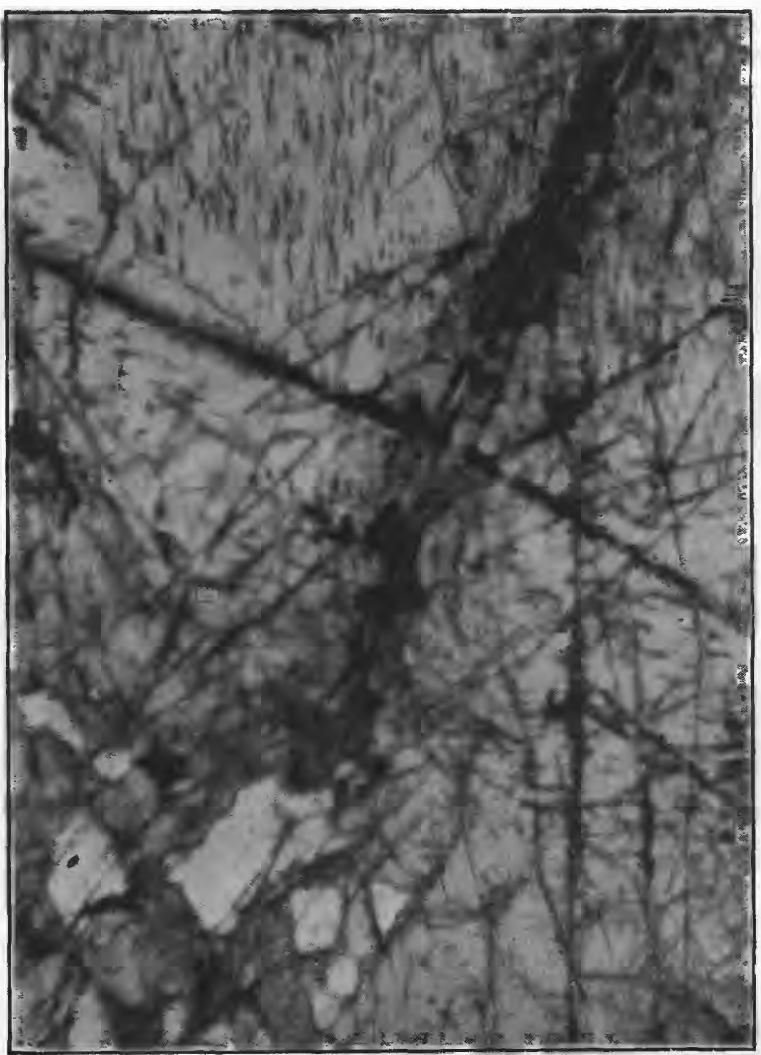

D 


\section{PLATE 14}

A. Photomicrograph of a thin section of nelsonite from the property of the American Lead Co. on the Bob Hite farm about a mile north of Roseland. Apatite (gray) is cut by veinlets of ilmenite (black). $\times 48$.

B. Photomicrograph of a polished specimen of nelsonite from Allen Creek, about half a mile west of Rose Union. Shows the rounding of apatite grains (white) and their embayment by ilmenite (black) $\times 10$.

C. Photomicrograph of a specimen from the mine of the Southern Mineral Products Corporation. The light-colored partly rounded grains are apatite. The groundmass is largely fine-grained biotite which has formed by the replacement of feldspar. Near the upper right-hand corner and along the left margin are residual areas of only partly replaced feldspar with the perthitic structure preserved. Black areas are ilmenite. $\times 24$.

D. Photomicrograph of a thin section of a large crystal of clinohypersthene from the mine of the American Rutile Co. The dark areas are ilmenite, which has formed abundantly along two fractures. Near the top are elongated lenses of ilmenite that has formed in the cleavage planes of the clinohypersthene. These lenses are so thin that they transmit light and are lavender purple in color. $\times 48$. 


\section{PLATE 15}

PHOTOMICROGRAPHS OF LEAN NELSONITE FROM THE MINE OF THE SOUTHERN MINERAL PRODUCTS CO. SHOWING REPLACEMENT OF ANORTHOSITE BY NELSONITE

In all specimens the white areas are apatite and the black ones are ilmenite

A. Residual grain of antiperthitic feldspar near the center. This is enclosed in a biotite-actinolite aggregate that has completely replaced feldspar. $\times 86$.

$B$. Similar material with a partly replaced feldspar grain in the lower part. Replacement, which has followed the perthitic lenses, has partly preserved the structure. $\times 86$.

C. Photomicrograph of hornblende-rich nelsonite. The central area is a lens of andesine that has escaped replacement, although most of the specimen is similar to the augenlike areas shown in $D$. At the right of the main andesine mass are isolated areas of andesine separated by shear zones. Gray area at the upper right corner is apatite. $\quad \times 86$.

$D$. Several striated grains along the lower right side represent partly replaced feldspar grains. Ghostlike outlines of the totally replaced feldspar grains are faintly discernible throughout the specimen. The groundmass is biotite and actinolite. $\times 48$. 


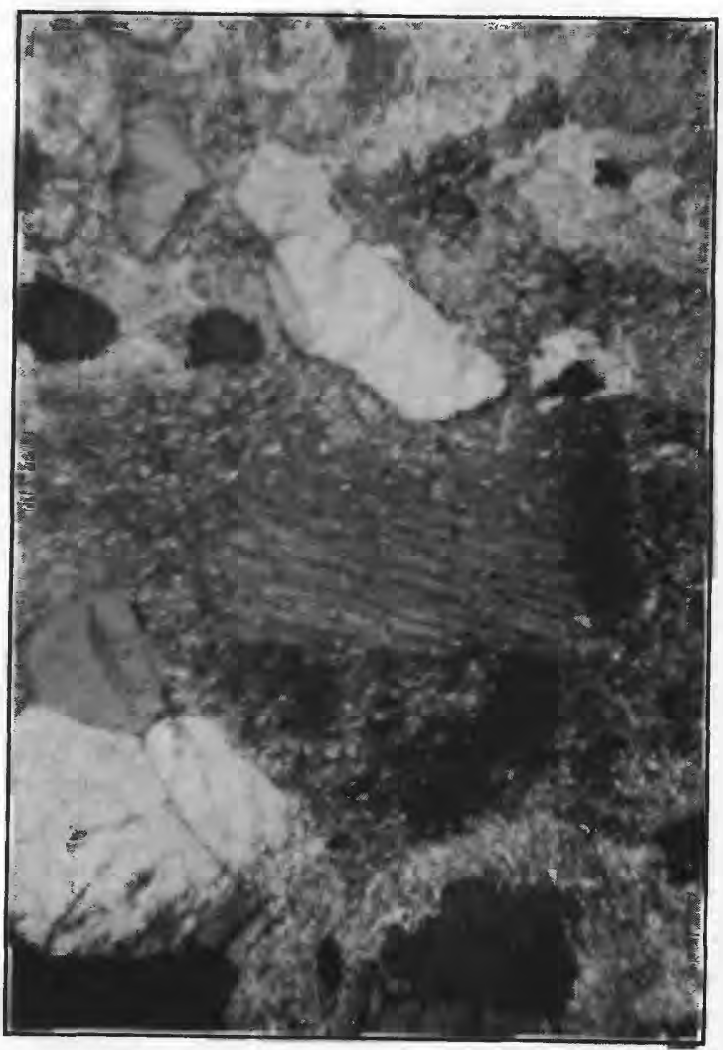

A

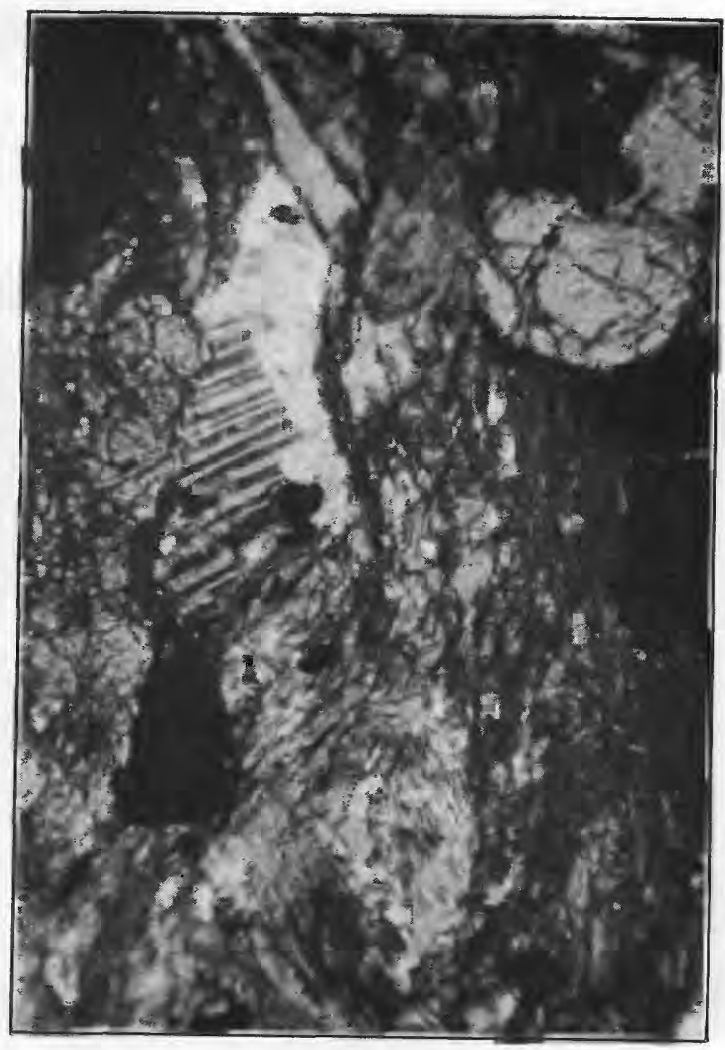

C

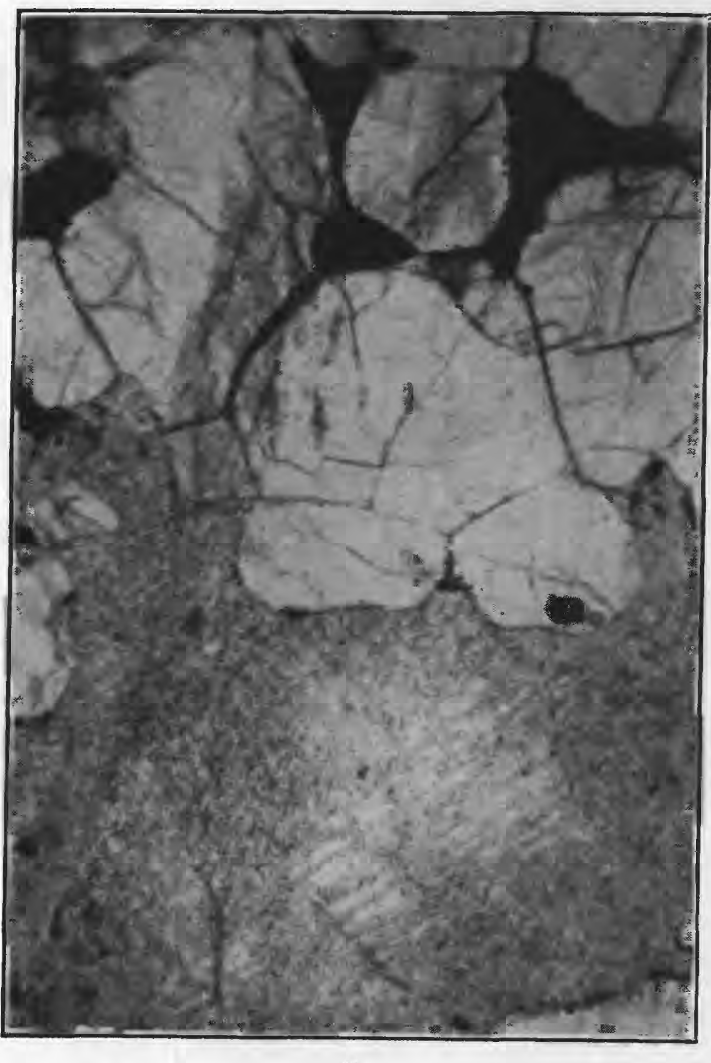

B

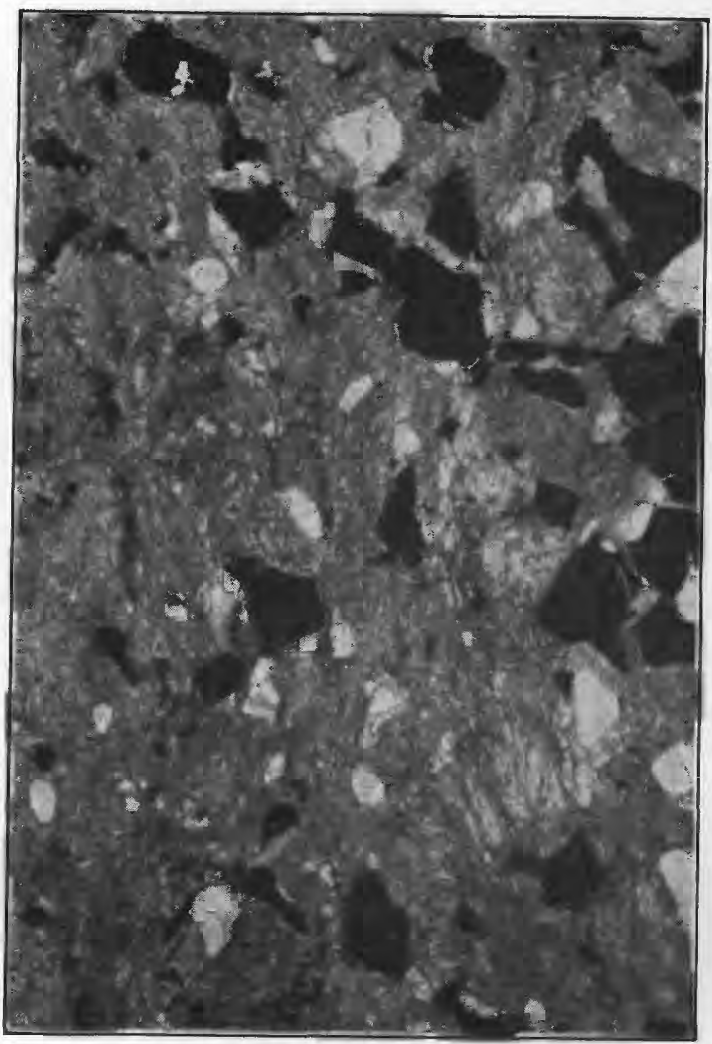




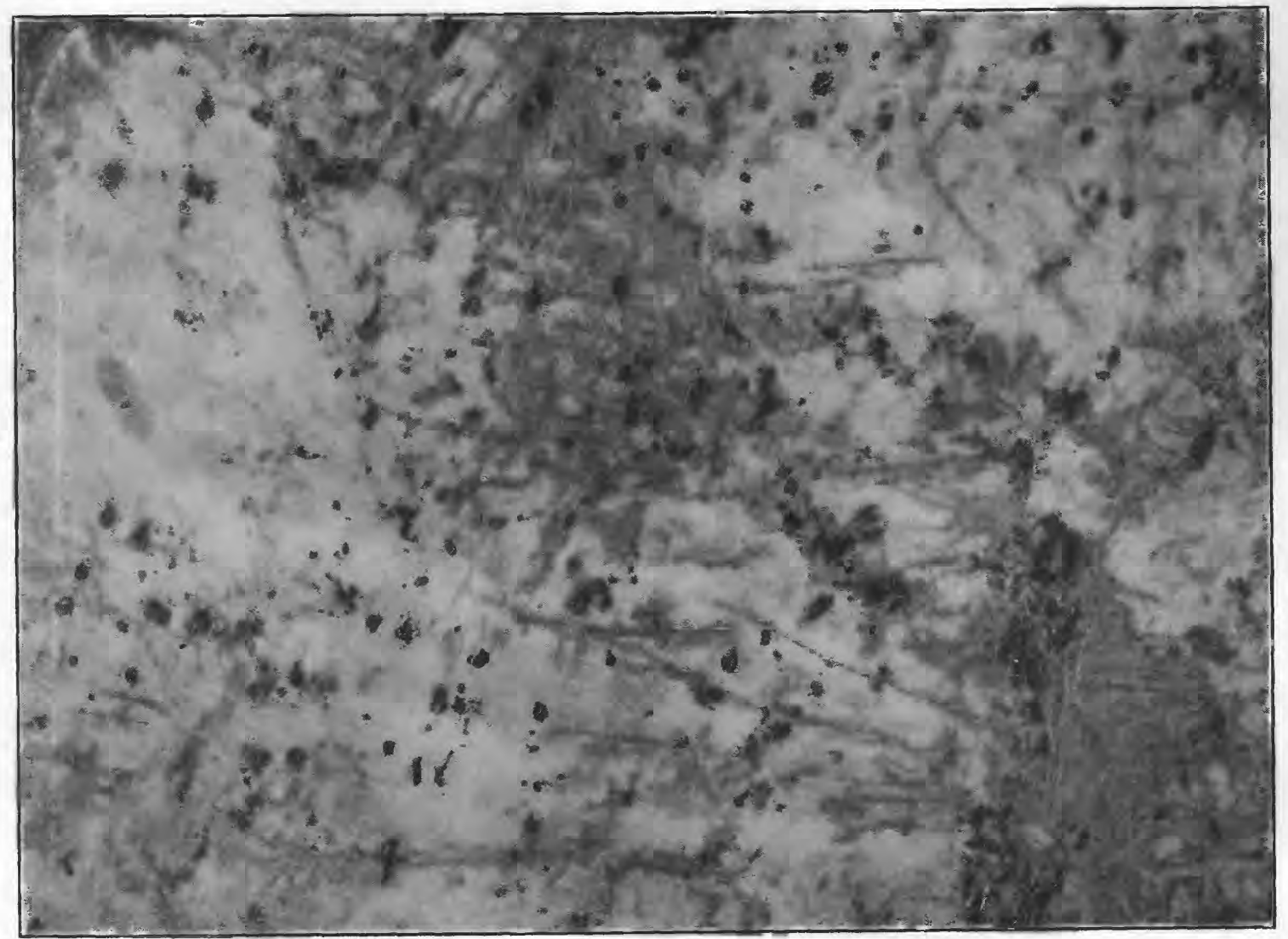

4

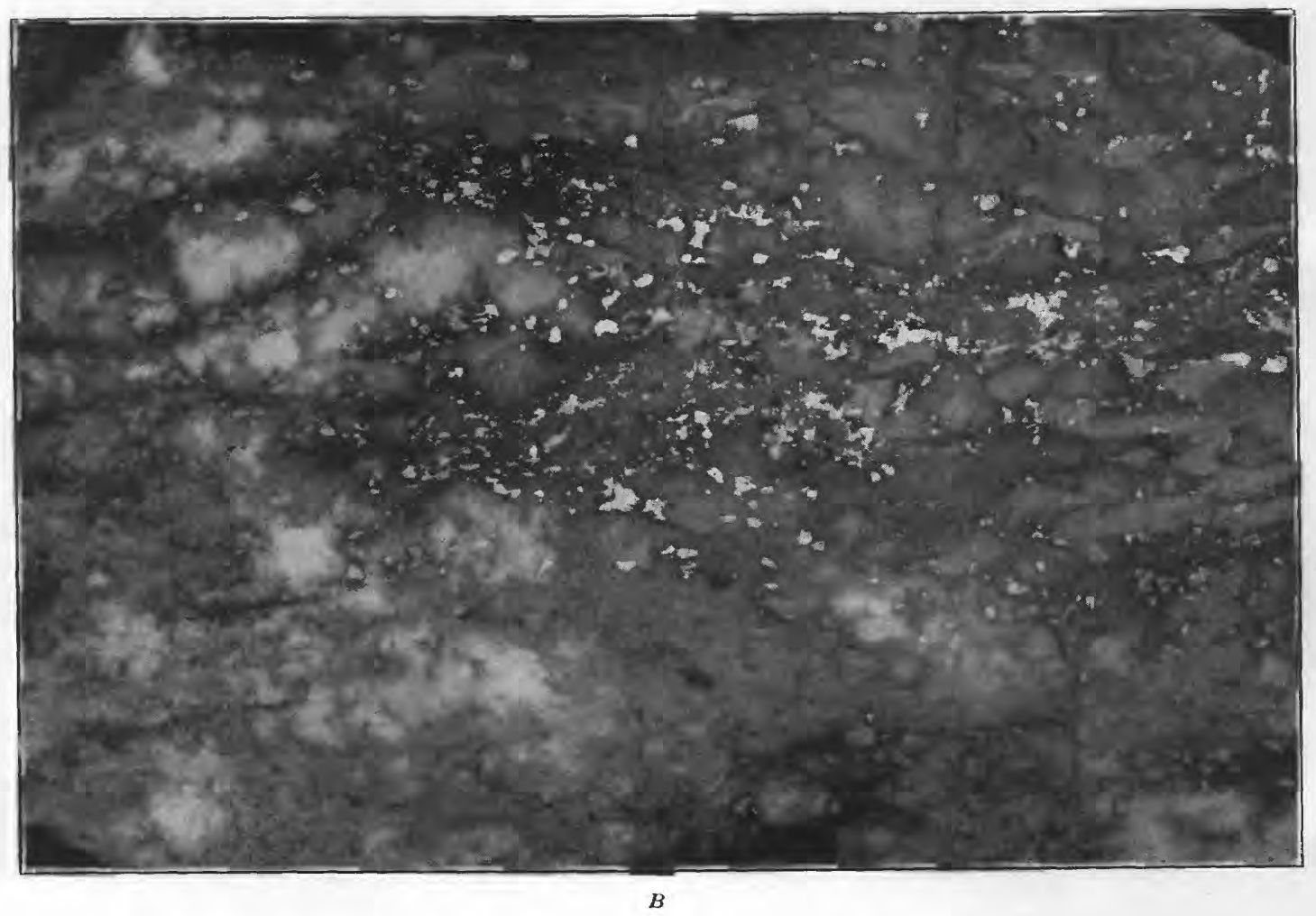




\section{PLATE 16}

\section{PHOTOGRAPHS OF POLISHED SPECIMENS SHOWING REPLACEMENT}

\section{Natural size}

A. Specimen from the mine of the American Rutile Co. The feldspar has been very thoroughly granulated and cut by a system of fractures along which the secondary silicates clinozoisite, tremolite, and sericitic muscovite have formed. Black areas are rutile. Note the tendency for rutile to be associated with areas of extreme alteration of feldspar or with small fractures.

B. Part of one of the anorthosite lenses in schistose country rock on the south border of the anorthosite mass at Rose Mills. Photographed in reflected light. The white areas are rutile. Near the right side are numerous rounded or elongated and sharply bounded areas of rutilated quartz. White cloudlike areas are slightly altered feldspar, and the darker gray is feldspar that has been largely replaced by secondary silicates. Black areas are shear zones flled with clinohypersthene and its alteration products. 


\section{PLATE 17}

$A, B$, and $C$. Photomicrographs, by reflected light, of polished specimens of clinohypersthene from the mine of the American Rutile Co. Dark-gray areas are quartz, the white areas are ilmenite, and the black roughly horizontal areas are fractures, enclosing clinohypersthene. $A$ and $B$ show quartz and ilmenite that have formed broad veinlets in the cleavage planes of clinohy persthene. The very narrow veinlets are rutile. Diagonal lines are due to polishing. $C$ is a large mushroomlike vein of quartz with grains of ilmenite cutting across the cleavage of a clinohypersthene crystal. $\times 16$.

$D$. Thin section of a rounded grain of apatite enclosed in ilmenite and cut by fractures in which ilmenite has formed. $\times 48$. 


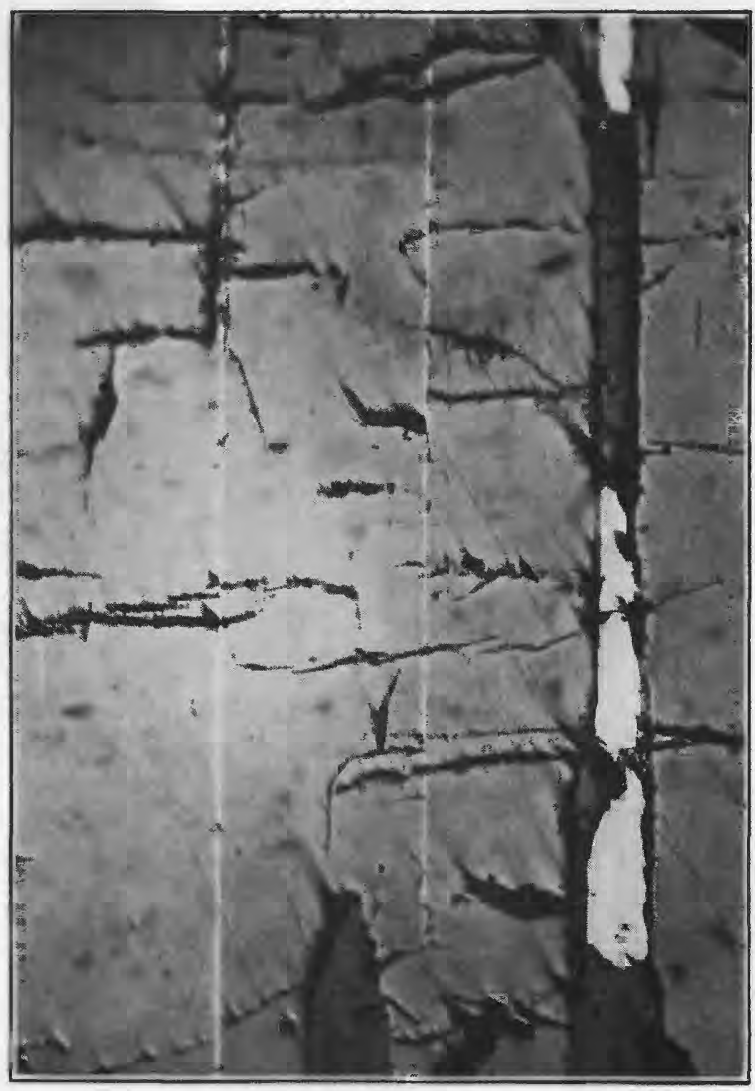

A

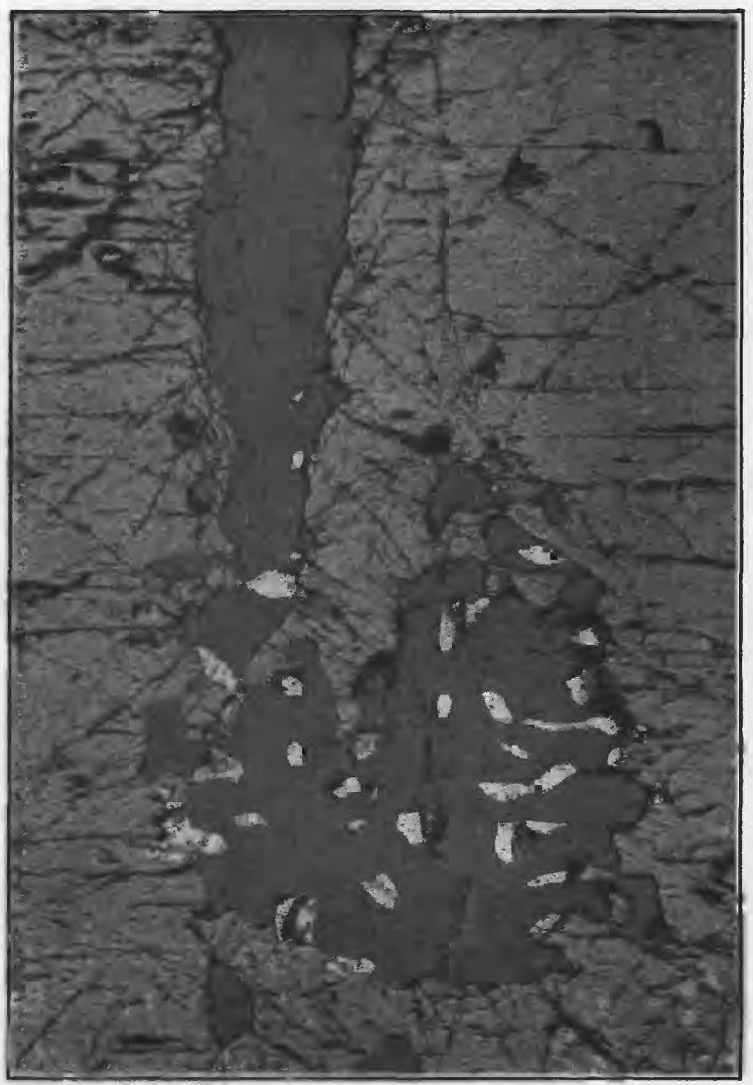

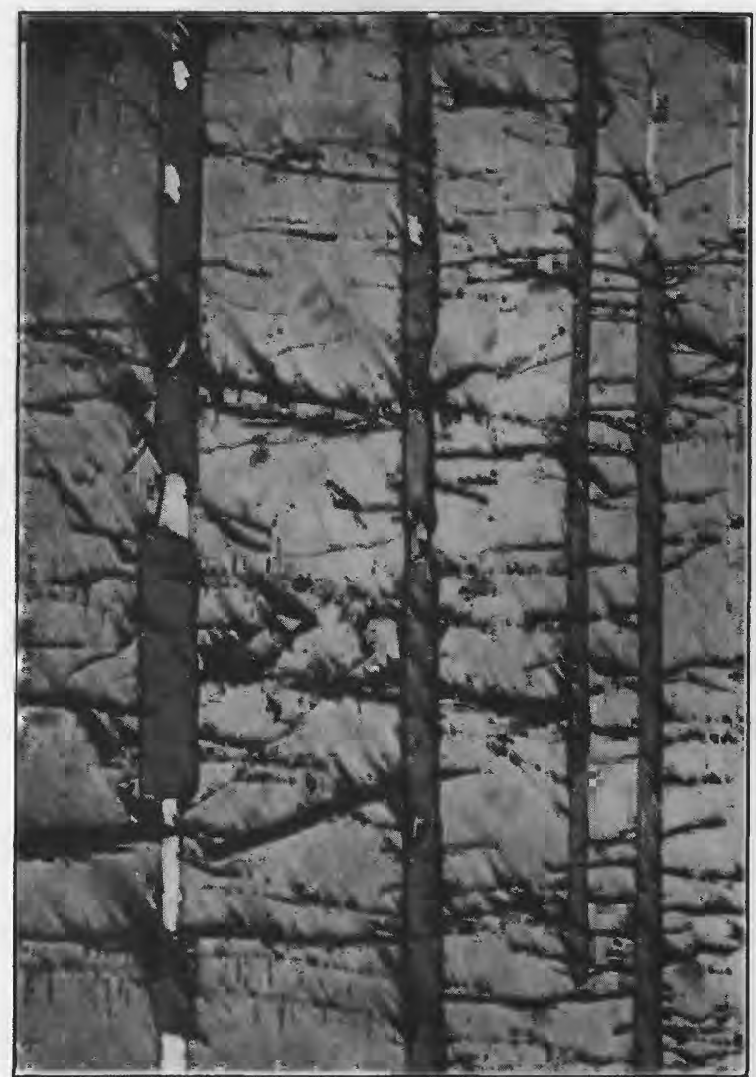

B

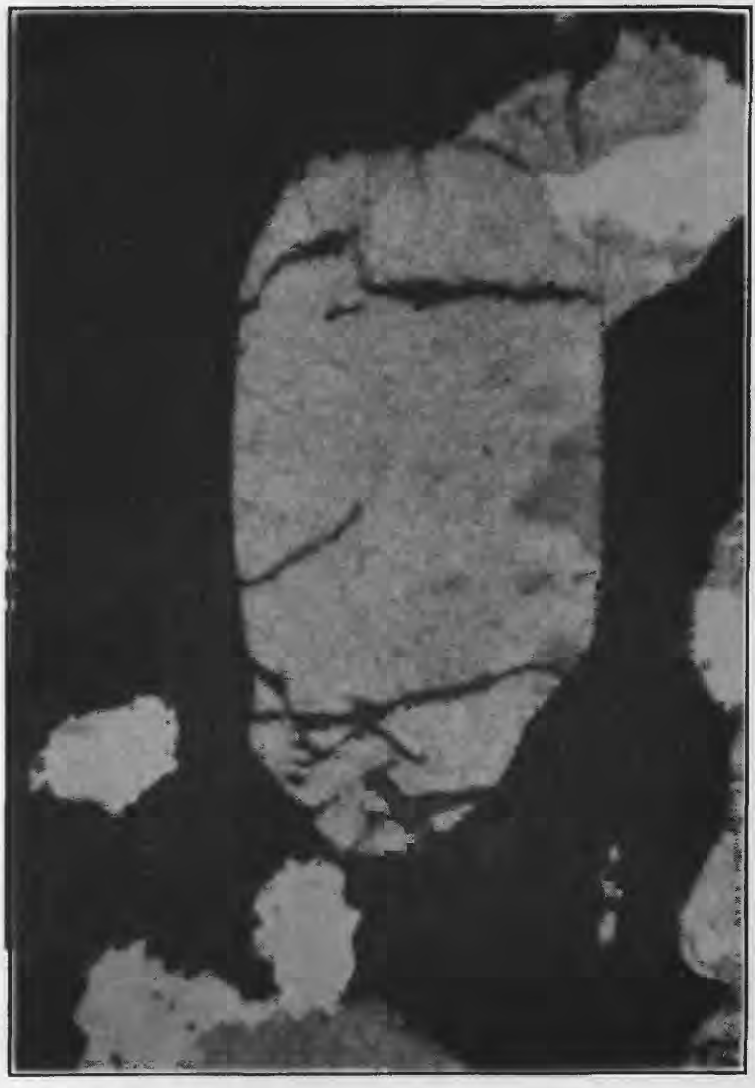

D 
GEOLOGICAL SURVEY

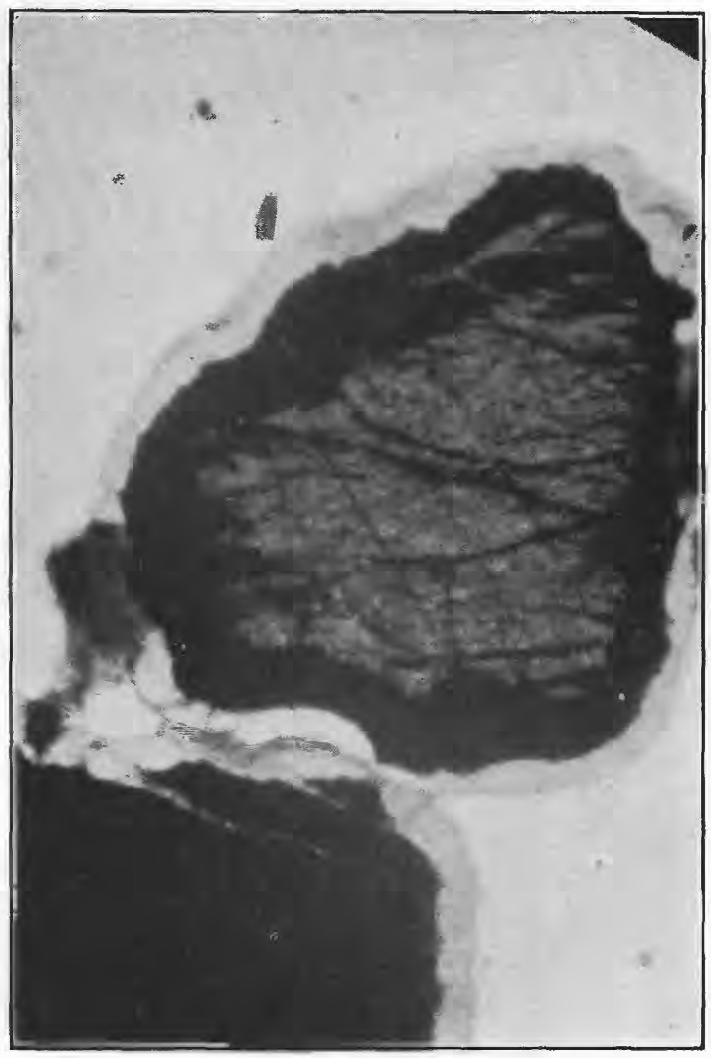

$A$

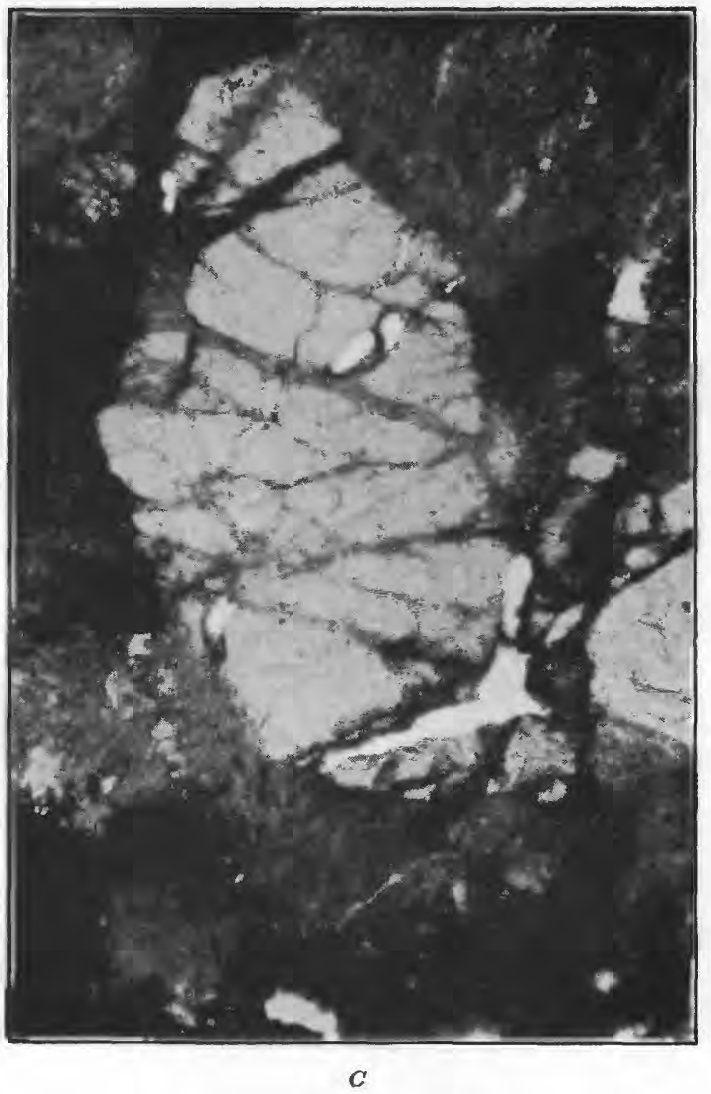

PROFESSIONAL PAPER 198 PLATE 18

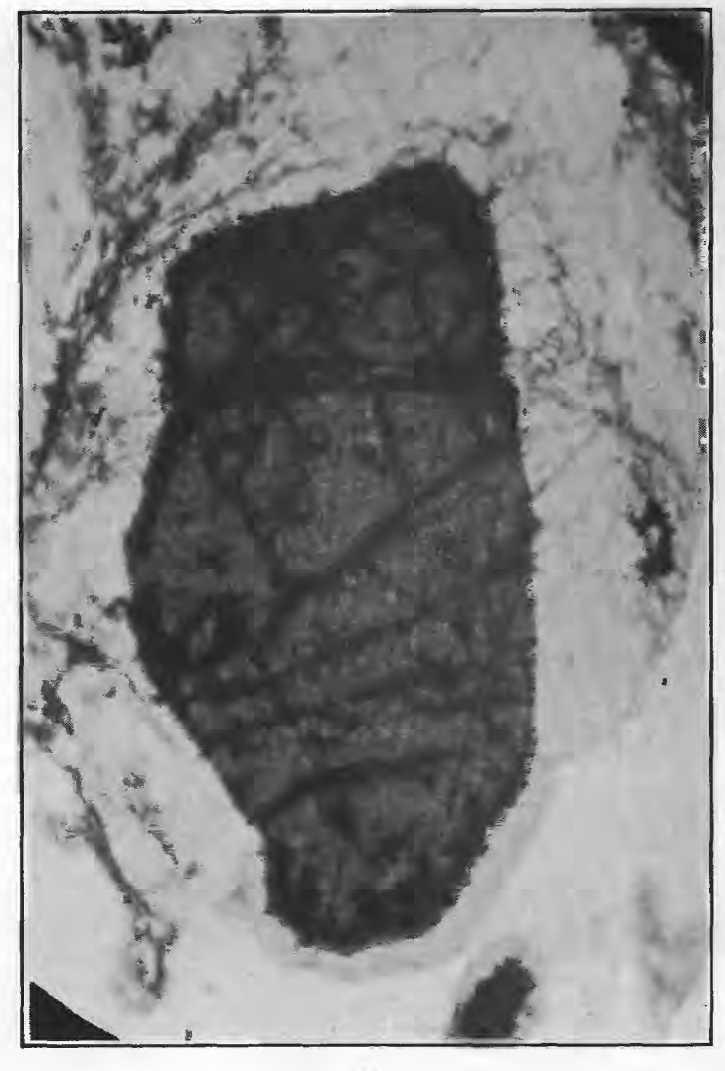

$B$

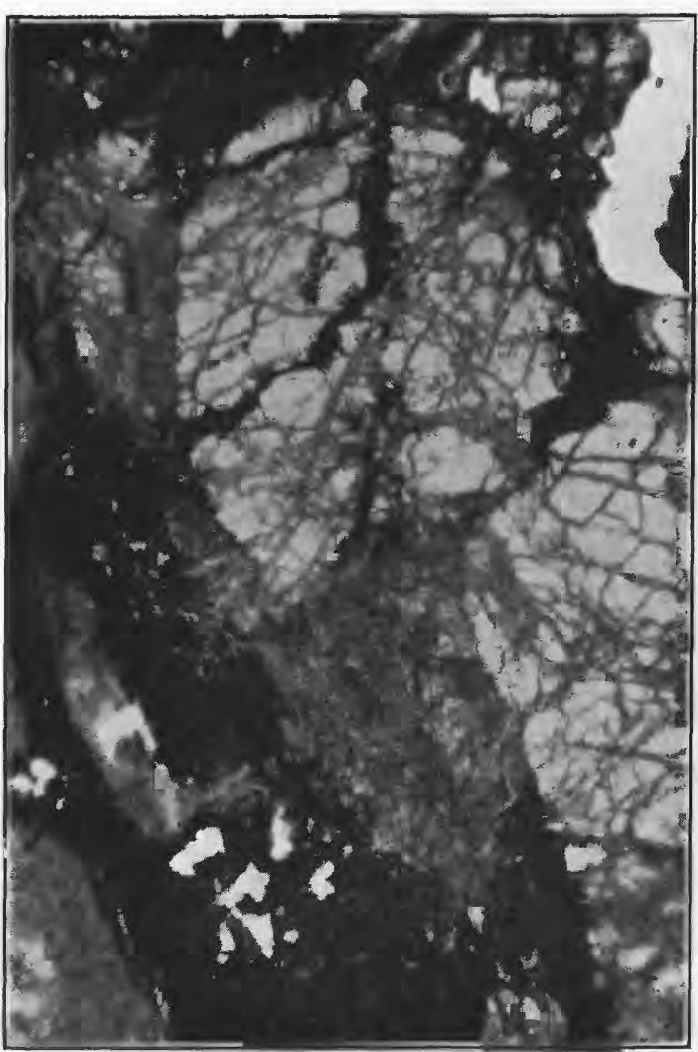

D 


\section{PLATE 18}

PHOTOMICROGRAPHS OF THIN SECTIONS SHOWING REPLACEMENT. $\times 24$

$A$ and $B$. Crystals of rutile enclosed in anorthosite from the mine of the American Rutile Co. The gray inner part is rutile and the black along the outer border and along fractures is ilmenite that has replaced rutile. The light-colored, nearly white border material is sphene "leucoxene."

$C$ and $D$. Biotite nelsonite from the Bob Hite farm about a mile north of Roseland. The white areas are apatite that has been fractured and the fractures filled with later minerals. The gray veinlets are biotite and the black ones ilmenite. The gray areas in the groundmass are also biotite. 


\section{PLATE 19}

\section{PHOTOGRAPHS OF SPECIMENS FROM THE ROSELAND AREA SHOWING REPLACEMENT}

$A$ and $B$. Polished specimens of rutile nelsonite from the Giles property, a quarter of a mile west of Roseland. The white veinlets are sphene "leucoxene" that has formed by replacement of rutile (black) along fractures. The gray, horizontal areas in $B$ and the diagonal area extending across $A$ represent zones of close shearing. The white area on the right of $A$ is partly replaced anorthosite. In the lower half of $B$ several gray, only slightly elongated areas are apatite. $\times 3$.

$C$. Thin section showing irregular tonguelike areas and isolated grains of rutile (black) that have formed in anorthosite (white background). The gray areas are sphene. $\times 8$.

D. Thin section of rutile (light gray) with ilmenite (black) that has formed along fractures. Still later sphene has replaced both rutile and ilmenite. $\times 40$.

58 
GEOLOGICAL SURVEY

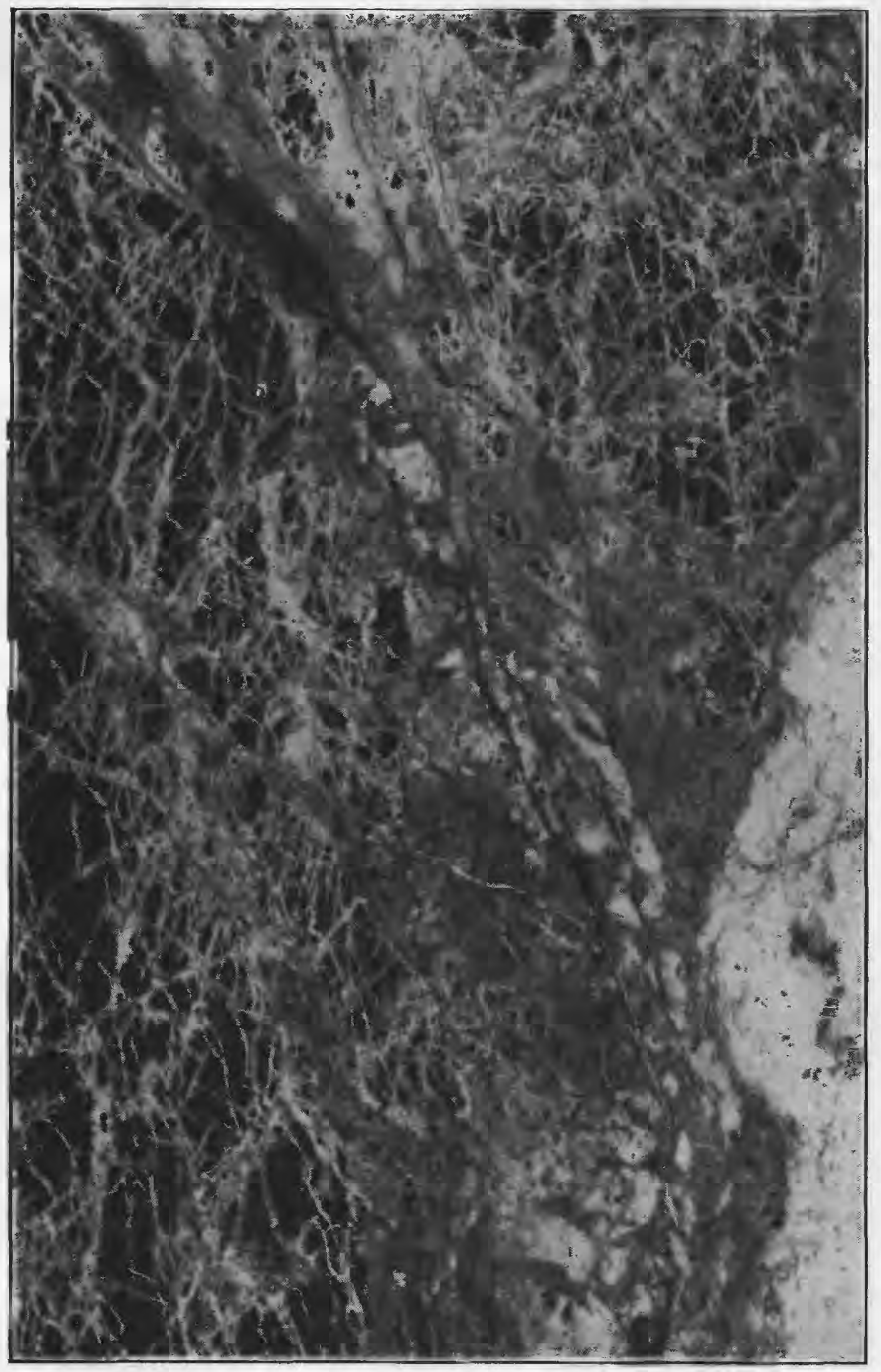

A

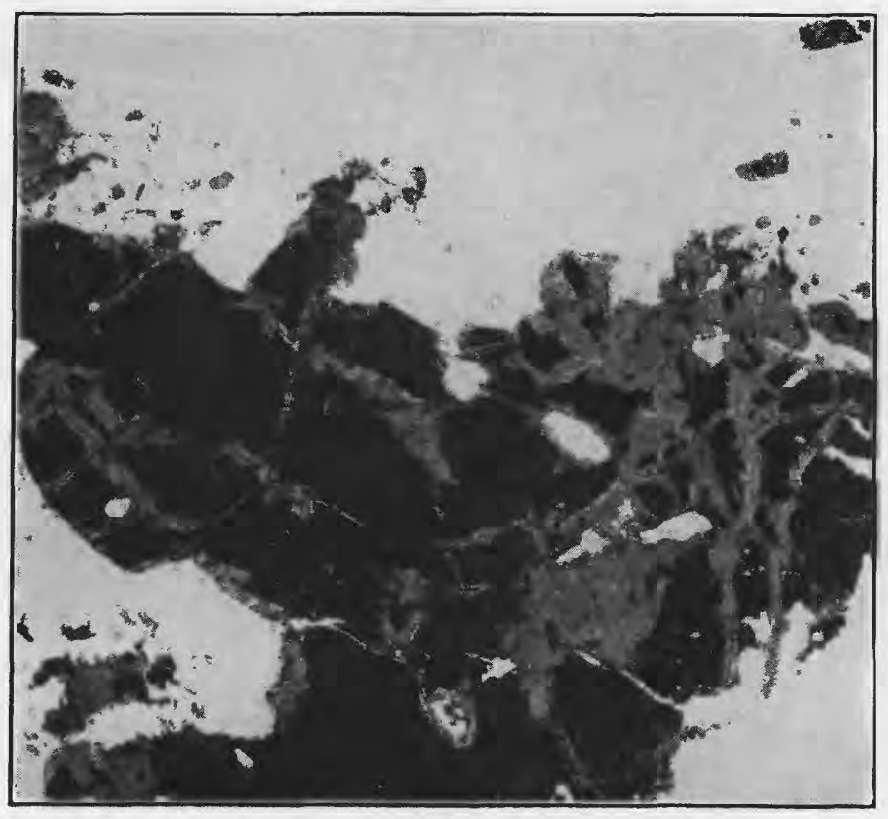

C
PROFESSIONAL PAPER 198 PLATE 19

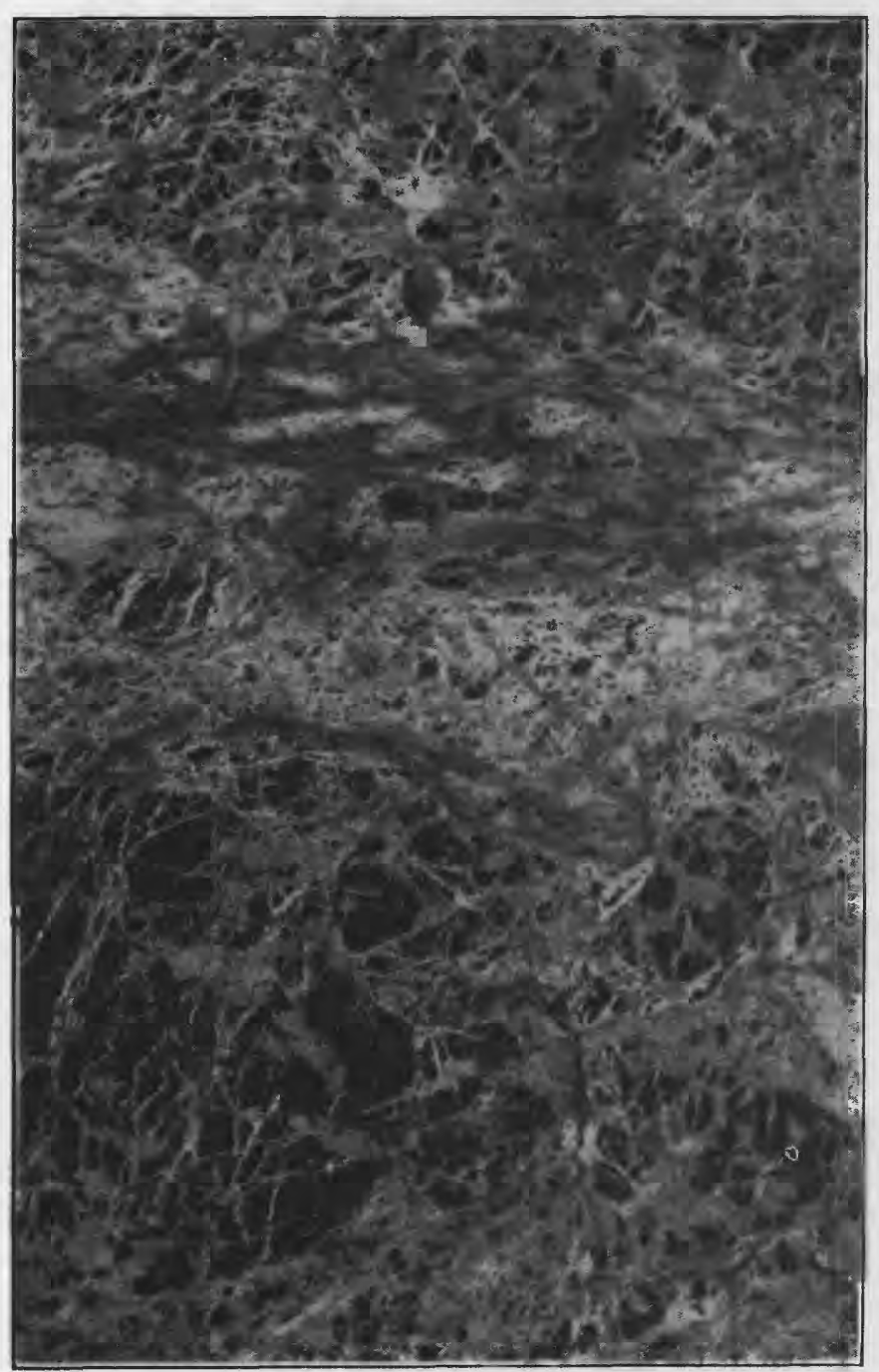

$B$

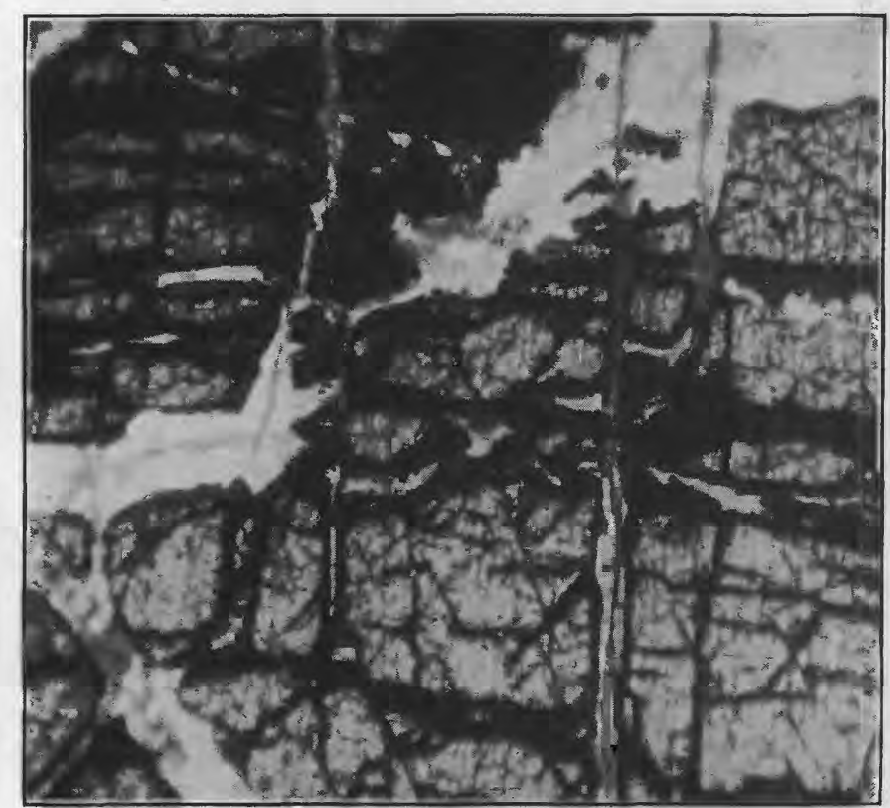

D 



\section{INDEX}

\begin{abstract}
Acknowledgments.

Actinolite mode of occurronce of

Albitization, physicochemical processes controlling -

Alumina and alkalies, relation between.

Amphiboles, distribution and properties of ....... 12-13, pls. $4, D, 9,13,15, C$

Analyses -

Andesine, antiperthitic, optical properties of paragenesis of ........ 22 (insert)

Anorthosite, andesine, occurrence and origin of

border facies of . . ......... 4,17

oligoclase, occurrence and origin of

Apatite, distribution and chemical character of paragenesis of

8, 22 (insert), pls.
\end{abstract}

Balk, Robert, quoted.

Bowen, N. L., quoted...

$27,28-29$

analysis by

Buddington, A. F., quoted...... 16

Calcite, distribution of

Calcium, segregation of ....

Charlevoix district, Quebec, titanium deposits of ..................... 23

Clinohypersthene, optical and chemical properties of

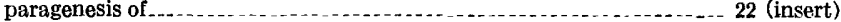

Clinozoisite, optical and chemical properties of paragenesis of ................................... 22 (insert), pls. 2-4 Cobalt-bearing clay, occurrence and chemical character of

Dikes, ferromagnesian, origin of

Eskola, Pentti, quoted

$10,11,12,13,33$

Fairchild, J. G., analyses by

Feldspar, optical and chemical properties of

11 , pls. $3, C, 10$

Fenner, C. N., quoted

Ferromagnesian lenses. See Lenses.

Ferromagnesian rocks, character of

Gillson, J. L., quoted...

Gneiss, injection, origin of

Graphite, occurrence and character of

Ilmenite, distribution and character of

14, pls. $13, A, 14, A$ paragenesis of $\quad 18-10,22$ (insert), pls. $9, A, 13,14,15,18, A, B, C, 19, \mathrm{D}$ Ilmenite nelsonite, mineral composition of . .

ron, segregation of pls. $4, D, 1314, A, B, C, 15,17, D, 18, C, D$

Location of the area

Lenses, ferromagnesian, origin and relations of 36-37

Lovingston granite gneiss. See Quartz monzonite. pls. $5, B, 6-9,14, D, 16, B, 17, A, B, C$

Lynchburg gneiss, relations of

3

Magmatic segregation, factors influencing

Magnesium, segregation of

- 27-38

Magnet Cover, Ark., titanium deposits of

$286089-41-1$

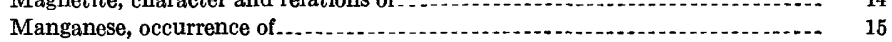

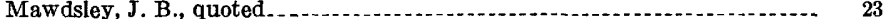

Mica, distribution and character of .......................... 13, $\mathrm{p}^{\top}, C, D$ paragenesis of ........ 19, 22 (insert), pls. 2-4

Mineralization, physicochemical processes controlling ...................... 26-38

Minerals, physicochemical processes controlling paragenesis of ............ 26-38 sequence of ................... 22 (insert) See also individual minerals.

Nelsonite, distribution and character of $7-10$ pls. $4, D, 13,14, A, B, C, 15,17, D, 18, C, D, 19$

paragenesis of $20-22$, pls. $11,12, A, 13,14, A, D, 15,17, L, 18, C, D$

Origin of the rocks and minerals

Osborne, F. F., quoted...... 23

Paragenesis of titanium minerals 22,22 (insort), $37-38$ See also individual rocks and minerals.

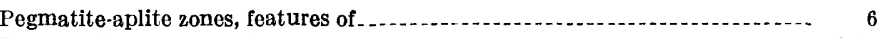
Petrography, features of .

Phosphorus, magmatic segregation of

Pre-Cambrian rocks, distribution and character of .................... 2-3

Pyrite, character and relations of ................... pls. $B, 9, B$

Pyrrhotite, character and relations of

Quartz, paragenesis of ................................ 17, 22 (insert), pl. $B$ rutilated, distribution and character of Quartz lenses, distribution and character of $\ldots$ Quartz monzonite, distribution and character of.......................... 2-3

Reaction principle, discussed .......................................... 27

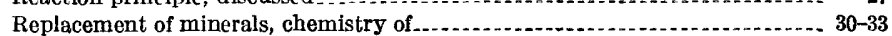

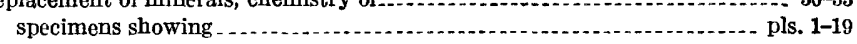
Replacing solutions, character of ........................... 28-30 Roseland anorthosite, distribution, character, and relations of. 2-6, pls. 1-3, 10, 16, $B$ Rutile, distribution and chemical character of .................. 13-14. pl. 18, $C$ paragenesis of ........ 18-19, 22 (insert), pls. 1, $5, A, 11,18, A, B, 19, D$ Rutile nelsonite, character of .................. 19

St. Urbain, Quebec, titanium deposits of

Scope of the report

$\begin{array}{lll} & 12\end{array}$

Sphalerite, occurrence of -

Sphene, distribution and chemical character of _.................... 14, pl. 19

Stability of minerals, physicochemical processes influencing

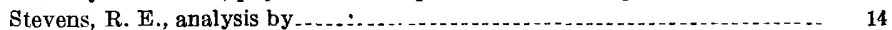

Taber, Stephen, and Watson, T. L., quoted

Thornton, W. M., Jr., analyses by

Titanium, segregation of

Tremolite, mode of occurrence of .................................... pls. 2-4

Washington, H. S., analyses by ........................................ 35

Watson, T. L., and Taber, Stephen, quoted..... 3

Wells, R. C., analysis by .......... 15

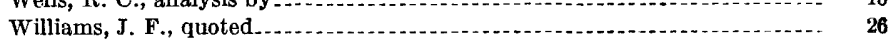

